\title{
Discovery of a First-in-Class Inhibitor of the Histone Methyltransferase SETD2 Suitable for Preclinical Studies
}

John W. Lampe, Joshua S. Alford, P. Ann Boriak-Sjodin, ${ }^{\dagger}$ Dorothy Brach, Kat Cosmopoulos, Kenneth W. Duncan, ${ }^{\dagger}$ Sean T. Eckley, Megan A. Foley, ${ }^{\ddagger}$ Darren M. Harvey, ${ }^{\mathbb{P}}$ Vinny Motwani, Michael J. Munchhof," Alejandra Raimondi, Thomas V. Riera, Cuyue Tang, ${ }^{ \pm}$Michael J. Thomenius, ${ }^{\wedge}$ Jennifer Totman, Neil A. Farrow*

Epizyme, 400 Technology Square, Cambridge, MA 02139

\section{Table of Contents}

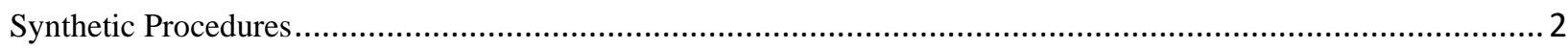

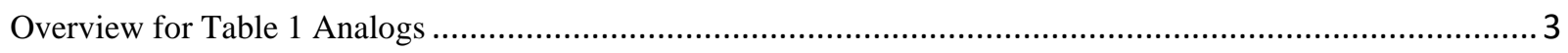

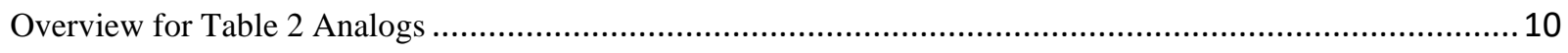

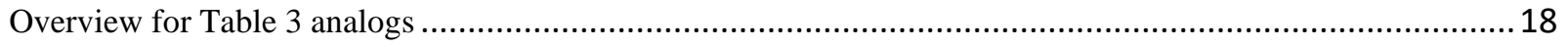

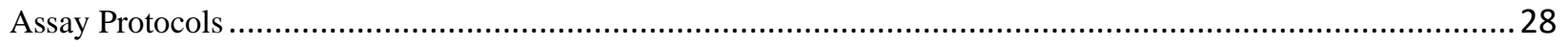

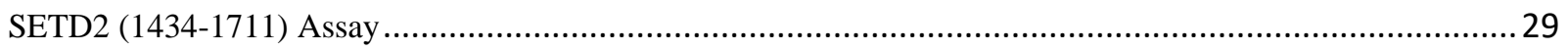

In-cell western (ICW) assay of SETD2 Inhibitors (A549 assay) ............................................................. 30

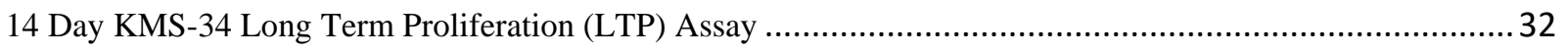

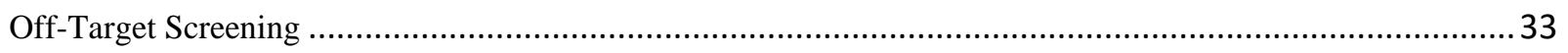

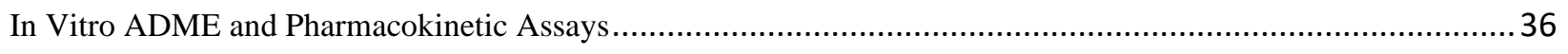

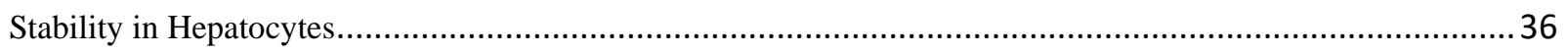

CYP Inhibition in Human Liver Microsomes .................................................................................. 38

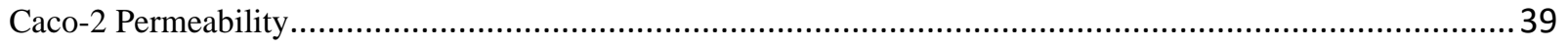

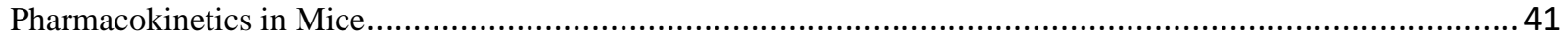

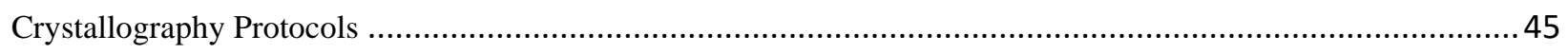

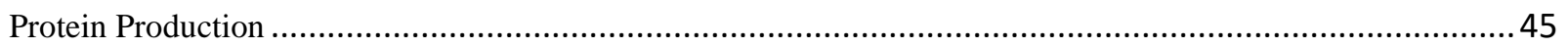

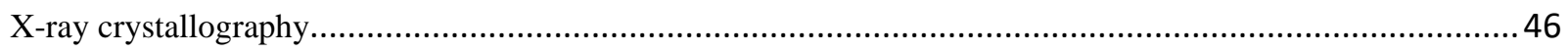

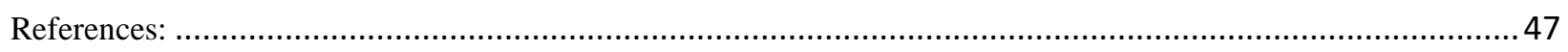




\section{Synthetic Procedures}

Proton NMR spectra were recorded on Agilent 400 or $300 \mathrm{MHz}$ spectrometers. Proton chemical shifts are reported in ppm $(\delta)$ relative to tetramethylsilane and calibrated using the residual solvent resonance (DMSO- $d 6, \delta 3.33 \mathrm{ppm}$; methanol- $d 4, \delta 3.31 \mathrm{ppm}$ ). Data are reported as follows: chemical shift (multiplicity [singlet (s), doublet (d), doublet of doublets (dd), doublet of doublets of doublets (ddd), doublet of doublets of triplets (ddt), doublet of triplets (dt), doublet of triplets of doublets of doublets (dtdd), triplet of doublets (td), triplet of doublets of doublets (tdd), triplet of doublets of triplets (tdt), triplet of triplets (tt), triplet of quartets (tq), quartet (q), quartet of doublets (qd), quartet of triplets (qt), pentet (p), pentet of doublets (pd), septet (sept), multiplet (m)], coupling constants [Hz], integration, specific proton assignment).

Unless otherwise noted, all NMR spectra were acquired at ambient temperature. Analytical thin-layer chromatography (TLC) was performed using EMD Millipore silica gel 60 F254 precoated plates $(0.25 \mathrm{~mm}$ thickness) and were visualized by irradiation with UV light $(254 \mathrm{~nm})$ and staining with KMnO4. TLC Rf values are reported. Normal phase flash chromatography was performed using Silicycle silica gel (particle size 32-63 $\mu \mathrm{m}$ ). Reversed phase chromatography used C-18 silica and was performed on a Biotage Isolera One purification system. All chemicals were purchased commercially and used as received unless otherwise noted. Building blocks that are commercially available from local vendors were purchased and used as received.

LC-MS analytical method: The instrument used for LC-MS analysis was a Shimadzu LCMS-2000 equipped with 2 LC-30AD pumps for a binary gradient, degasser, autosampler, PDA model SPD-M20A, D2 lamp, 190-400 nm, MS parameter: pos/neg 90-900, nebulizing gas flow: $1.5 \mathrm{~mL} / \mathrm{min}$, gas temp: $250{ }^{\circ} \mathrm{C}$.

Method 1: Kinetex EVO C18, 50x2.1 mm, $2.6 \mu \mathrm{m}$, Temp $35^{\circ} \mathrm{C}$, flow $1.0 \mathrm{~mL} / \mathrm{min}$, gradient: $\mathrm{t}_{0}=10 \% \mathrm{~B}, \mathrm{t}_{2.0 \mathrm{~min}}=$ $95 \%$ B, $t_{2.70 \min }=95 \%$ B, $t_{2.80 \min }=10 \%$ B. Mobile Phase A: Water $+6.5 \mathrm{mM} \mathrm{NH}_{4} \mathrm{HCO}_{3}(\mathrm{pH}=10) / \mathrm{Mobile}$ Phase B: $\mathrm{MeCN}$.

Method 2: Shim-pack XR-ODS, 50x3.0 mm, $2.2 \mu \mathrm{m}$, Temp $35^{\circ} \mathrm{C}$, flow $1.2 \mathrm{~mL} / \mathrm{min}$, gradient: $\mathrm{t}_{0}=5 \% \mathrm{~B}, \mathrm{t}_{2.0 \mathrm{~min}}=$ $95 \%$ B, $\mathrm{t}_{2.70 \min }=95 \%$ B, $\mathrm{t}_{2.80 \mathrm{~min}}=10 \%$ B. Mobile Phase A: Water $+0.05 \%$ TFA/Mobile Phase B: MeCN + 0.05\% TFA.

Method 3: Halo C18, 50x3.0 mm, $2.7 \mu \mathrm{m}$, Temp $45^{\circ} \mathrm{C}$, flow $1.5 \mathrm{~mL} / \mathrm{min}$, gradient: $\mathrm{t}_{0}=5 \% \mathrm{~B}, \mathrm{t}_{3.25 \mathrm{~min}}=45 \% \mathrm{~B}$, $\mathrm{t}_{4.00 \min }=100 \% \mathrm{~B}, \mathrm{t}_{4.60 \mathrm{~min}}=100 \% \mathrm{~B}, \mathrm{t}_{4.7 \mathrm{~min}}=5 \%$ B Mobile Phase A: Water $+0.05 \%$ TFA/Mobile Phase B: MeCN + $0.05 \%$ TFA.

Method 4: Cortecs C18, 50x2.1 mm, $2.7 \mu \mathrm{m}$, Temp $40{ }^{\circ} \mathrm{C}$, flow $1.0 \mathrm{~mL} / \mathrm{min}$, gradient: $\mathrm{t}_{0}=10 \% \mathrm{~B}, \mathrm{t}_{1.00 \mathrm{~min}}=100 \% \mathrm{~B}$, $\mathrm{t}_{1.50 \min }=100 \% \mathrm{~B}, \mathrm{t}_{1.60 \min }=10 \% \mathrm{~B}$, Mobile Phase A: Water $+0.05 \%$ FA/Mobile Phase B: MeCN + 0.05\% FA. 
Overview for Table 1 Analogs: Analogs of the early hit $\mathbf{3}$ were generally prepared by coupling of commercially available indole acids with benzylic amines which are also commercially available. The preparation of 4-fluoro-7methyl- $1 \mathrm{H}$-indole-2-carboxylic acid $\mathbf{3 6}$ is as follows:

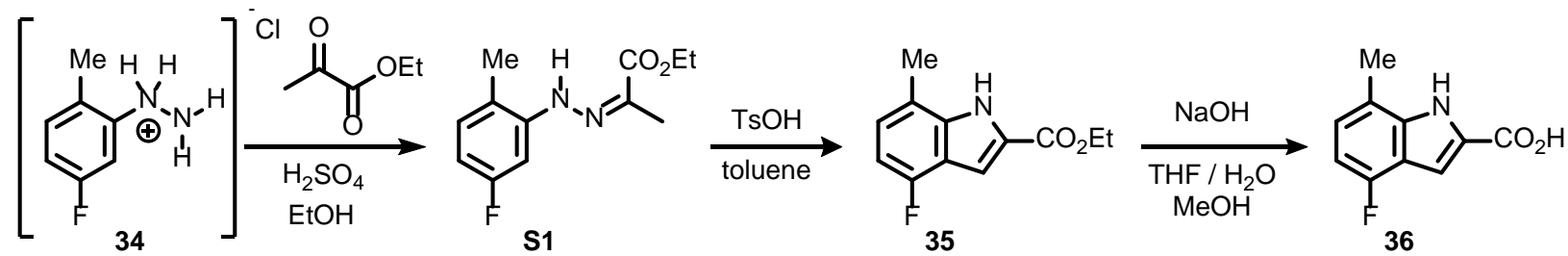

Supplementary Scheme S1: Preparation of 4-fluoro-7-methyl-1H-indole-2-carboxylic acid 36.

To a reaction vessel containing a solution of (5-fluoro-2-methylphenyl)hydrazine hydrochloride 34 (100 g, $572.7 \mathrm{mmol}$, 1.0 equiv) in ethanol $(400 \mathrm{~mL})$ was added sulfuric acid $(10 \mathrm{~mL})$ followed by ethyl 2-oxopropanoate (66 $\mathrm{g}, 1.2$ equiv) under a nitrogen atmosphere at $25{ }^{\circ} \mathrm{C}$. The resulting mixture was aged with stirring for 2 hours, at which time the reaction was shown to be complete by LC-MS. The product mixture was then concentrated under reduced pressure (12 mbar), and the solids were collected by filtration furnishing ethyl (2E)-2-[2-(5-fluoro-2methylphenyl) hydrazin-1-ylidene]propanoate S1 (120 g, 88\% yield) as a yellow solid. LCMS: Method 2 (ESI, $\mathrm{m} / \mathrm{z}): \mathrm{RT}=1.40 \mathrm{~min}, \mathrm{~m} / \mathrm{z}=239.0[\mathrm{M}+\mathrm{H}]^{+}($calc $\mathrm{m} / \mathrm{z}=238.1) ;{ }^{1} \mathbf{H}$ NMR $(400 \mathrm{MHz}$, DMSO-d6) $\delta 11.96(\mathrm{~d}, J=2.0$ Hz, 1H), 7.15 (m, 2H), 6.62 (m, 1H), 4.25 (q, $J=7.1 \mathrm{~Hz}, 2 \mathrm{H}), 2.12$ (d, $J=9.3 \mathrm{~Hz}, 6 \mathrm{H}), 1.29$ (t, $J=7.1 \mathrm{~Hz}, 3 \mathrm{H})$.

To a reaction vessel containing a solution of ethyl (2E)-2-[2-(5-fluoro-2-methylphenyl) hydrazin-1ylidene]propanoate $\mathbf{S 1}$ (40 g, $167.9 \mathrm{mmol}, 1.0$ equiv) in toluene $(400 \mathrm{~mL}$ ) was added 4-methylbenzene-1-sulfonic acid (50 g, $290.4 \mathrm{mmol}, 1.70$ equiv) under a nitrogen atmosphere. The resulting mixture was aged for 18 hours at $100{ }^{\circ} \mathrm{C}$ with stirring, at which time the reaction was shown to be complete by LC-MS. The product mixture was then concentrated under reduced pressure (12 mbar), diluted with ethyl acetate $(100 \mathrm{~mL})$ followed by saturated aqueous ammonium chloride $(300 \mathrm{~mL}$ ) and transferred to a separatory funnel. The layers were separated, and the aqueous layer was re-extracted with additional ethyl acetate $(2 \times 150 \mathrm{~mL})$. The organic layers were combined and dried over magnesium sulfate. The dried solution was filtered through a plug of celite and the filtrate was concentrated under reduced pressure (12 mbar). The residue obtained was purified by flash-column chromatography (eluting with $20 \%$ ethyl acetate/petroleum ether), fractions collected and concentrated, and the product residue was recrystallized from boiling ethanol to afford ethyl 4-fluoro-7-methyl- $1 \mathrm{H}$-indole-2-carboxylate 35 (9.0 g, 24\% yield) as a yellow solid. LCMS: Method 2 (ESI, $\mathrm{m} / \mathrm{z})$ : RT $=1.35 \mathrm{~min}, \mathrm{~m} / \mathrm{z}=222.0[\mathrm{M}+\mathrm{H}]^{+}$(calc $\left.\mathrm{m} / \mathrm{z}=221.1\right) ;{ }^{1} \mathbf{H}$ NMR $(400 \mathrm{MHz}$, DMSO-d6) $\delta 12.07$ (s, 1H), 7.17 (d, $J=2.1 \mathrm{~Hz}, 1 \mathrm{H}), 7.00$ (m, 1H), 6.77 (m, 1H), 4.36 (q, $J=7.1 \mathrm{~Hz}, 2 \mathrm{H}), 2.49$ (d, $J$ $=1.0 \mathrm{~Hz}, 3 \mathrm{H}), 1.35$ (t, $J=7.1 \mathrm{~Hz}, 3 \mathrm{H})$.

Sodium hydroxide ( $8 \mathrm{~g}, 200.0 \mathrm{mmol}, 5.0$ equiv) dissolved in water $(50 \mathrm{~mL})$ was added to a solution of ethyl 4-fluoro-7-methyl- $1 \mathrm{H}$-indole-2-carboxylate 35 (9.1 g, $41.1 \mathrm{mmol}, 1.0$ equiv) in tetrahydrofuran $(150 \mathrm{~mL})$ and methanol $(2 \mathrm{~mL})$. The reaction mixture was stirred at $21{ }^{\circ} \mathrm{C}$ for 6 hours. The product mixture was then concentrated under reduced pressure (12 mbar). The residue solution obtained was adjusted to $\mathrm{pH}=4$ with hydrochloric acid (3 M). The product was collected by filtration to afford 4-fluoro-7-methyl- $1 H$-indole-2-carboxylic acid $\mathbf{3 6}$ (8.0 g, 81\%) as a brown solid. LCMS: Method 4 (ESI, $\mathrm{m} / \mathrm{z}$ ): RT $=0.65 \mathrm{~min}, \mathrm{~m} / \mathrm{z}=192.1[\mathrm{M}-\mathrm{H}]^{+}$(calc $\mathrm{m} / \mathrm{z}=193.1 ;{ }^{1} \mathbf{H}$ NMR (400 MHz, DMSO-d6) $\delta 13.12(\mathrm{br} \mathrm{s}, 1 \mathrm{H}), 11.96(\mathrm{~s}, 1 \mathrm{H}), 7.11(\mathrm{~s}, 1 \mathrm{H}), 6.98(\mathrm{dd}, \mathrm{J}=4.8,7.6 \mathrm{~Hz}, 1 \mathrm{H}), 6.75(\mathrm{dd}, \mathrm{J}=$ 7.8, $10.6 \mathrm{~Hz}, 1 \mathrm{H}), 2.45$ (s, 3H).

Analogs 3-15 were prepared via the following from the appropriate carboxylic acid: 


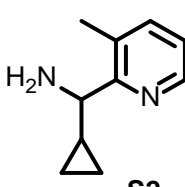

S2

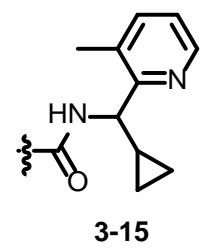

Supplementary Scheme S2: Preparation of analogs in Table 1.

General reaction procedure (GP1): To a reaction vessel containing the appropriate carboxylic acid (1.0 equiv), $N$ ethyl- $N$-isopropylpropan-2-amine (5.0 equiv), and cyclopropyl(3-methylpyridin-2-yl)methanamine (2 equiv) in DMF $(5 \mathrm{~mL})$ was added HATU (1.3 equiv) at $21{ }^{\circ} \mathrm{C}$. The reaction mixture was aged for $18 \mathrm{~h}$ with stirring, at which time the reaction was shown to be complete by TLC. The product mixture was then diluted with deionized water (10 $\mathrm{mL}$ ) and transferred to a separatory funnel containing ethyl acetate $(25 \mathrm{~mL})$. The layers were separated, and the aqueous layer was re-extracted with additional ethyl acetate $(2 \times 25 \mathrm{~mL})$. The organic layers were combined and dried over magnesium sulfate. The dried solution was filtered through a plug of celite and the filtrate was concentrated under reduced pressure (12 mbar). The residue was purified by Prep-HPLC with the following conditions: Waters 2767-2; Column: XBridge Shield Prep OBD C18 Column, 19×150 mm 5 um; Mobile Phase A: Water (10 mmol/L $\mathrm{NH}_{4} \mathrm{HCO}_{3}$ ), Mobile Phase B: MeCN; Flow rate: $10 \mathrm{~mL} / \mathrm{min}$; Gradient: $10 \% \mathrm{~B}$ to $30 \%$ in $2 \mathrm{~min}$, to $46 \%$ B in $10 \mathrm{~min}$, to $100 \%$ B in $1 \mathrm{~min} ; 254 \mathrm{~nm}$.

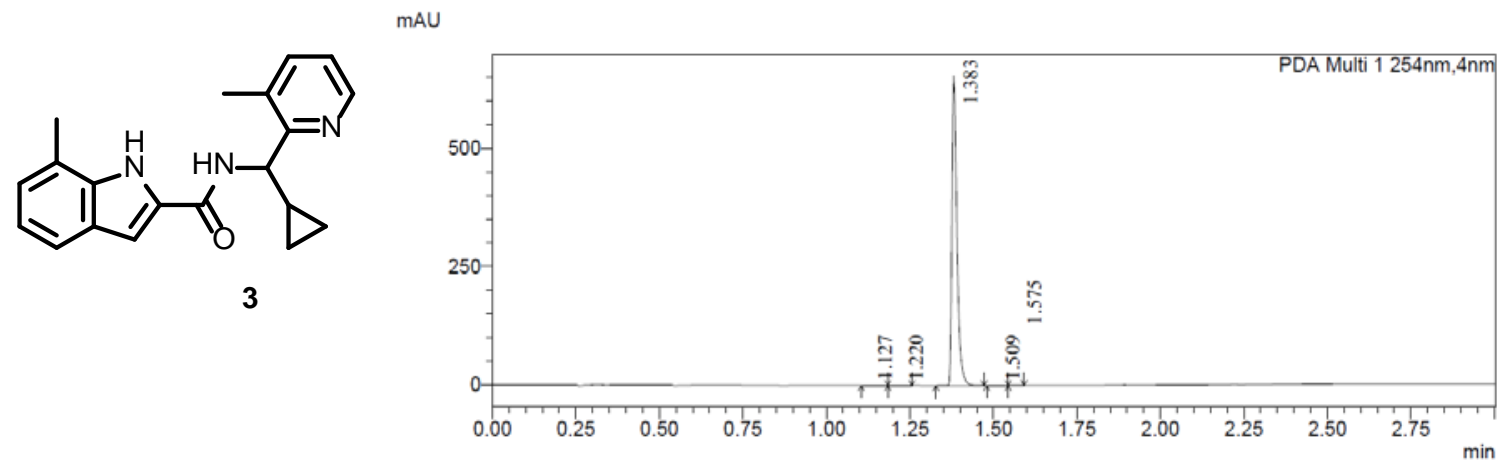

Prepared by using GP1 with 7-methyl- $1 H$-indole-2-carboxylic acid ( $100 \mathrm{mg}, 0.57 \mathrm{mmol}, 1.0$ equiv) and cyclopropyl(3-methylpyridin-2-yl)methanamine S2 (111 mg, $0.68 \mathrm{mmol}, 1.2$ equiv) resulting in $N$-(cyclopropyl(3methylpyridin-2-yl)methyl)-7-methyl-1H-indole-2-carboxamide 3 (95 mg, 52\% yield) as a white solid. Spectral data: LCMS: Method 2 (ESI, $\mathrm{m} / \mathrm{z}): \mathrm{RT}=1.38 \mathrm{~min}, \mathrm{~m} / \mathrm{z}=320.21[\mathrm{M}+\mathrm{H}]^{+}$(calc $\left.\mathrm{m} / \mathrm{z}=319.17\right) ;{ }^{1} \mathbf{H} \mathrm{NMR}(300 \mathrm{MHz}$, methanol-d4) $\delta 8.40$ (dd, J = 4.8, $1.2 \mathrm{~Hz}, 1 \mathrm{H}$ ), 7.62 (dd, J = 6.9, $0.9 \mathrm{~Hz}, 1 \mathrm{H}$ ), 7.44 (dd, J = 7.8, 0.6 Hz, 1H), 7.22 (dd, $\mathrm{J}=$ 7.8, $4.8 \mathrm{~Hz}, 1 \mathrm{H}), 7.14(\mathrm{~s}, 1 \mathrm{H}), 7.03(\mathrm{~m}, 1 \mathrm{H}), 6.97(\mathrm{~m}, 1 \mathrm{H}), 4.99$ (d, J = 8.7 Hz, 1H), $2.52(\mathrm{~s}, 3 \mathrm{H}), 2.49$ (s, 3H), 1.49-1.52 (m, 1H), 0.43-0.68 (m, 4H). 


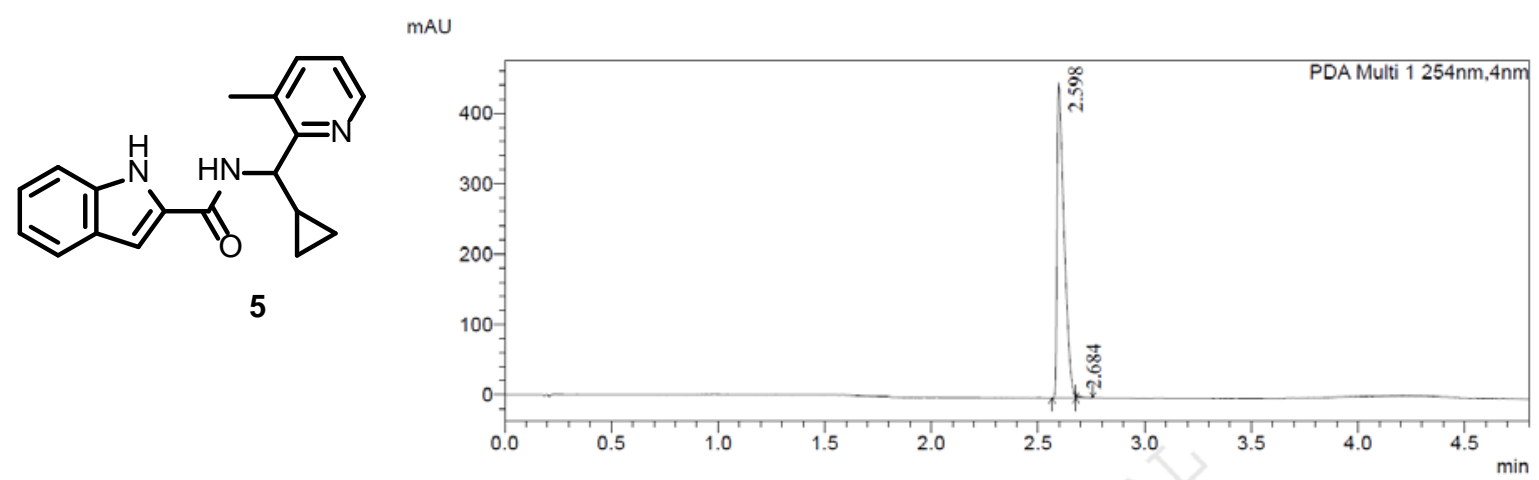

Prepared by using GP1 with $1 H$-indole-2-carboxylic acid (400 mg, $2.5 \mathrm{mmol}, 1.0$ equiv) and cyclopropyl(3methylpyridin-2-yl)methanamine S2 (441 mg, $2.7 \mathrm{mmol}, 1.1$ equiv) resulting in $\mathrm{N}$-(cyclopropyl(3-methylpyridin-2yl)methyl)-1H-indole-2-carboxamide 5 (257 mg, 25\% yield) as a white solid. Prep-HPLC: XSelect CSH Prep C18 OBD Column, 19×250 mm 5 um; Mobile Phase A: Water + 0.05\% TFA, Mobile Phase B: MeCN; Flow rate: 25 $\mathrm{mL} / \mathrm{min}$; Gradient: $17 \%$ B to $47 \%$ in $7 \mathrm{~min}, 254 \mathrm{~nm}, \mathrm{RT}=6.63 \mathrm{~min}$; Spectral data: LCMS: Method 3 (ESI, $\mathrm{m} / \mathrm{z}$ ): RT=2.60 min, $m / z=306.10[\mathrm{M}+\mathrm{H}]^{+}$(calc $\left.\mathrm{m} / \mathrm{z}=305.15\right) ;{ }^{1} \mathbf{H}$ NMR $(400 \mathrm{MHz}$, DMSO- $d 6) \delta 11.58(\mathrm{~s}, 1 \mathrm{H}), 9.01(\mathrm{~d}, J$ $=6.4 \mathrm{~Hz}, 1 \mathrm{H}), 8.54(\mathrm{~d}, J=4.4 \mathrm{~Hz}, 1 \mathrm{H}), 7.87$ (brs, $1 \mathrm{H}), 7.61$ (d, $J=8.0 \mathrm{~Hz}, 1 \mathrm{H}), 7.46$ (s, $1 \mathrm{H}), 7.40$ (d, $J=8.4 \mathrm{~Hz}$, 1H), 7.28 (brs, $1 \mathrm{H}), 7.18$ (t, $J=7.6 \mathrm{~Hz}, 1 \mathrm{H}), 7.03$ (t, $J=7.6 \mathrm{~Hz}, 1 \mathrm{H}), 4.74$ (t, $J=8.0 \mathrm{~Hz}, 1 \mathrm{H}), 2.47$ (s, 3H), $1.62-1.53$ (m, 1H), 0.65-0.38 (m, 4H).
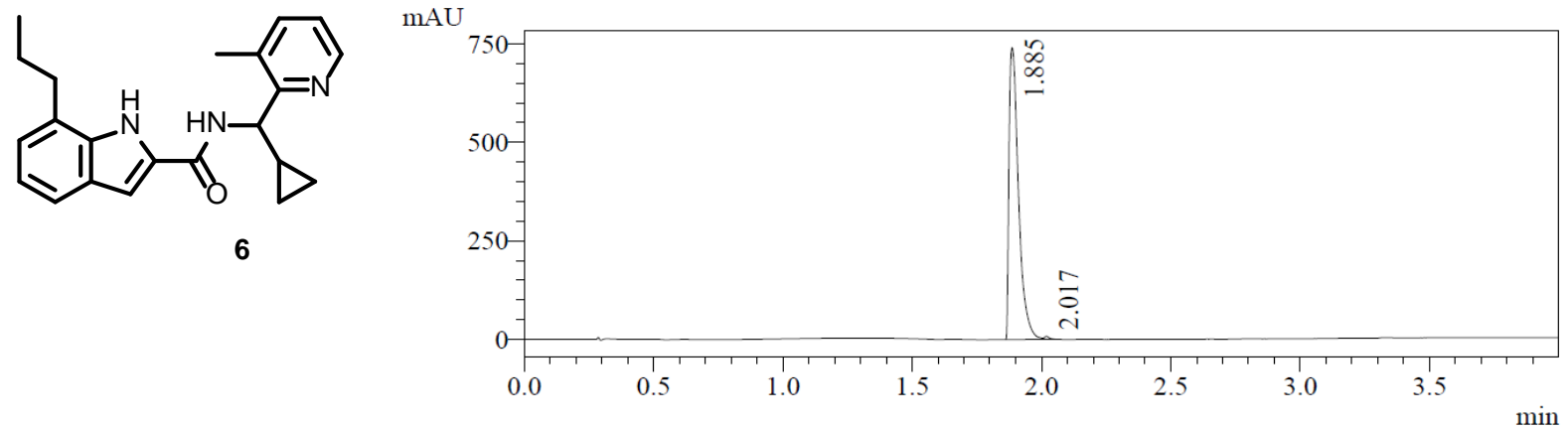

1 PDA Multi $1 / 254 \mathrm{~nm} 4 \mathrm{~nm}$

Prepared by using GP1 with 7-propyl-1H-indole-2-carboxylic acid (200 mg, $0.98 \mathrm{mmol}, 1.0$ equiv) and cyclopropyl(3-methylpyridin-2-yl)methanamine $\mathbf{S 2}(200 \mathrm{mg}, 1.23 \mathrm{mmol}, 1.2$ equiv) resulting in $\mathrm{N}$-(cyclopropyl(3methylpyridin-2-yl)methyl)-7-propyl-1H-indole-2-carboxamide 6 (99 mg, 22\% yield) as a white solid. Prep-HPLC: XSelect CSH Prep C18 OBD Column, 19×250 mm 5 um; Mobile Phase A: Water + 0.05\% TFA, Mobile Phase B: MeCN; Flow rate: $25 \mathrm{~mL} / \mathrm{min}$; Gradient: $17 \%$ B to $47 \%$ in $7 \mathrm{~min}, 254 \mathrm{~nm}$; Spectral data: LCMS: Method 2 (ESI, $\mathrm{m} / \mathrm{z}$ ): RT=1.89 min, $\mathrm{m} / \mathrm{z}=348.05[\mathrm{M}+\mathrm{H}]^{+}($calc $\mathrm{m} / \mathrm{z}=347.20) ;{ }^{1} \mathbf{H}$ NMR (300 MHz, methanol-d4) $\delta 8.49(\mathrm{~d}, J=4.2$ $\mathrm{Hz}, 1 \mathrm{H}), 7.98$ (d, $J=7.8 \mathrm{~Hz}, 1 \mathrm{H}$ ), 7.51 (dd, $J=7.5,5.1 \mathrm{~Hz}, 1 \mathrm{H}), 7.45$ (dd, $J=7.5,1.5 \mathrm{~Hz}, 1 \mathrm{H}), 7.19(\mathrm{~s}, 1 \mathrm{H}), 7.06-$ $6.98(\mathrm{~m}, 2 \mathrm{H}), 4.81(\mathrm{~s}, 1 \mathrm{H}), 2.87(\mathrm{t}, J=7.5 \mathrm{~Hz}, 2 \mathrm{H}), 2.57(\mathrm{~s}, 3 \mathrm{H}), 1.79-1.72(\mathrm{~m}, 2 \mathrm{H}), 1.63-1.52(\mathrm{~m}, 1 \mathrm{H}), 1.00(\mathrm{t}, J=$ $7.2 \mathrm{~Hz}, 3 \mathrm{H}), 0.85-0.48$ (m, 4H). 

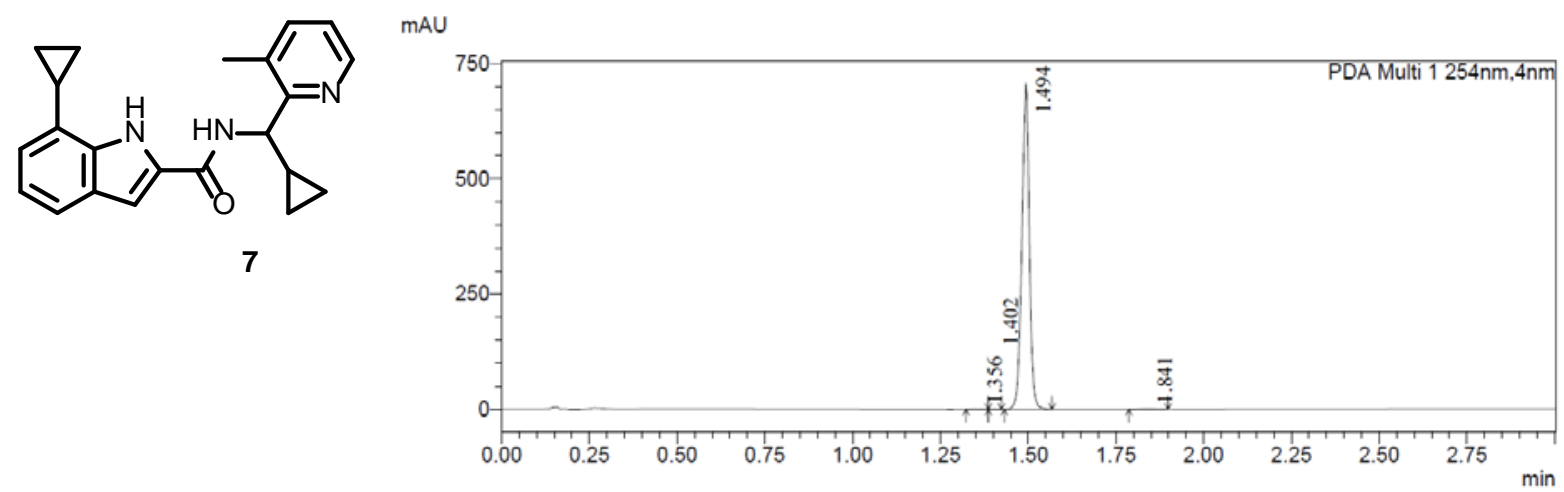

Prepared by using GP1 with 7-cyclopropyl-1H-indole-2-carboxylic acid (120 mg, $0.60 \mathrm{mmol}, 1.0$ equiv) and cyclopropyl(3-methylpyridin-2-yl)methanamine S2 (340 mg, $0.89 \mathrm{mmol}, 1.2$ equiv) resulting in 7-cyclopropyl- $N$ (cyclopropyl(3-methylpyridin-2-yl)methyl)- $1 H$-indole-2-carboxamide 7 (65 mg, 32\% yield) as a white solid. Spectral data: LCMS: Method 1 (ESI, $\mathrm{m} / \mathrm{z})$ : RT=1.49 min, $\mathrm{m} / \mathrm{z}=346.1[\mathrm{M}+\mathrm{H}]^{+}($calc $\mathrm{m} / \mathrm{z}=345.2) ;{ }^{1} \mathbf{H}$ NMR $(400$ MHz, DMSO-d6) $\delta 11.44$ (s, 1H), 8.92 (d, $J=7.6 \mathrm{~Hz}, 1 \mathrm{H}$ ), 8.44 (d, $J=3.6 \mathrm{~Hz}, 1 \mathrm{H}$ ), 7.59 (d, $J=7.2 \mathrm{~Hz}, 1 \mathrm{H}$ ), 7.39 (d, $J=8.0 \mathrm{~Hz}, 1 \mathrm{H}), 7.21(\mathrm{~m}, 2 \mathrm{H}), 6.94(\mathrm{t}, J=7.6 \mathrm{~Hz}, 1 \mathrm{H}), 6.72(\mathrm{~d}, J=6.8 \mathrm{~Hz}, 1 \mathrm{H}), 4.82(\mathrm{t}, J=8.4 \mathrm{~Hz}, 1 \mathrm{H}), 2.42$ (m, 4H), 1.63-1.59 (m, 1H), 1.02-0.98 (m, 2H), 0.73-0.71 (m, 2H), 0.59-0.55 (m, 1H), 0.49-0.43 (m, 2H), 0.38-0.36 (m, 1H).<smiles>Cc1cccnc1C(NC(=O)c1cc2c(F)ccc(C)c2[nH]1)C1CC1</smiles>

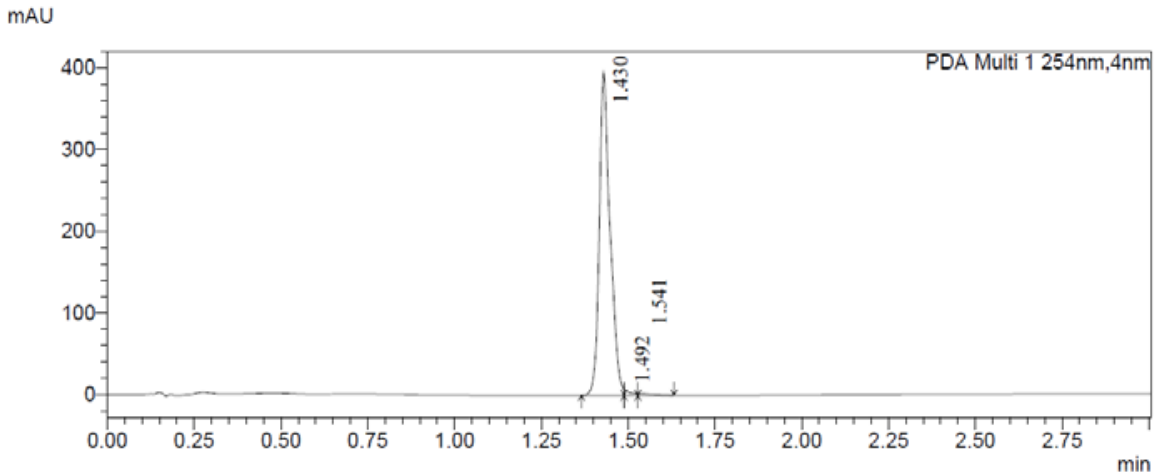

Prepared by using GP1 with 4-fluoro-7-methyl- $1 H$-indole-2-carboxylic acid 36 (150 mg, $0.78 \mathrm{mmol}, 1.0$ equiv) and cyclopropyl(3-methylpyridin-2-yl)methanamine $\mathbf{S 2}$ (216 mg, $1.33 \mathrm{mmol}, 1.7$ equiv) resulting in $N$-(cyclopropyl(3methylpyridin-2-yl)methyl)-4-fluoro-7-methyl-1H-indole-2-carboxamide 8 (50 mg, 19\% yield) as a white solid. Spectral data: LCMS: Method 1 (ESI, $\mathrm{m} / \mathrm{z})$ : RT=1.43 min, $\mathrm{m} / \mathrm{z}=338.0[\mathrm{M}+\mathrm{H}]^{+}$(calc $\left.\mathrm{m} / \mathrm{z}=337.2\right) ;{ }^{1} \mathbf{H}$ NMR $(400$ MHz, methanol-d4) $\delta 8.43$ (dd, $J=3.6,1.2 \mathrm{~Hz}, 1 \mathrm{H}$ ), 7.65 (dd, $J=7.6,0.8 \mathrm{~Hz}, 1 \mathrm{H}$ ), 7.26-7.23 (m, 2H), 6.99-6.96 (m, 1H), 6.67 (dd, $J=10.4,8.0 \mathrm{~Hz}, 1 \mathrm{H}), 5.00$ (d, $J=8.8 \mathrm{~Hz}, 1 \mathrm{H}$ ), 2.51 (s, 6H), 1.56-1.50 (m, 1H), 0.70-0.54 (m, 2H), 0.51-0.46 (m, 2H); ${ }^{19}$ F NMR (376 MHz, methanol- $\left.d 4\right) \delta$-127.9. 

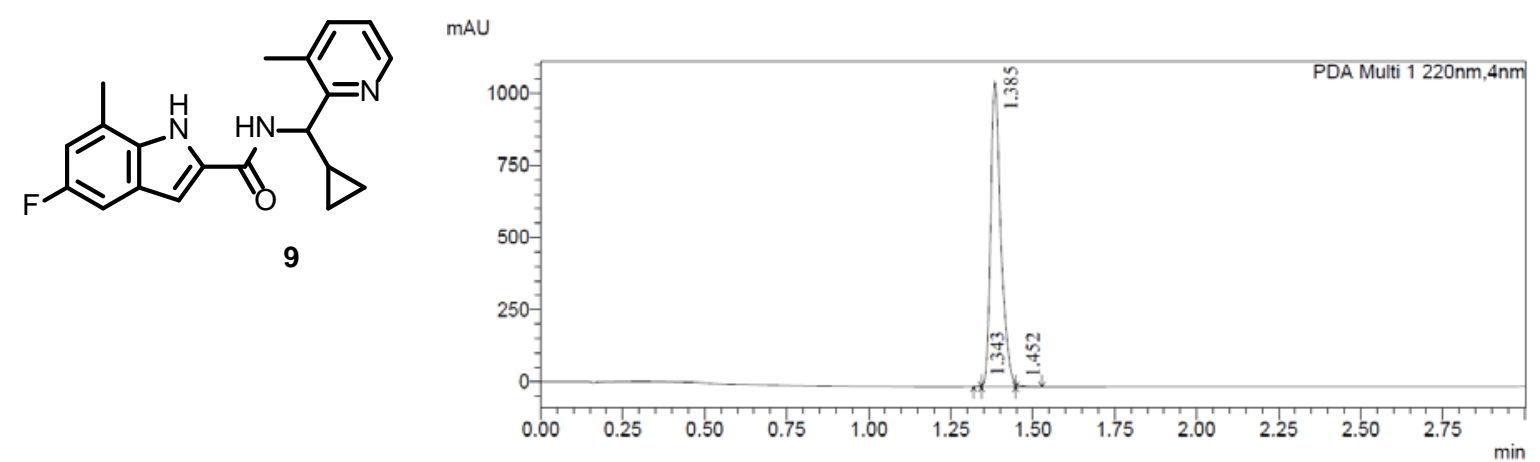

Prepared by using GP1 with 5-fluoro-7-methyl- $1 H$-indole-2-carboxylic acid (270 mg, $1.4 \mathrm{mmol}, 1.0$ equiv) and cyclopropyl(3-methylpyridin-2-yl)methanamine $\mathbf{S 2}$ (390 mg, $2.4 \mathrm{mmol}, 1.7$ equiv) resulting in $\mathrm{N}$-(cyclopropyl(3methylpyridin-2-yl)methyl)-5-fluoro-7-methyl-1H-indole-2-carboxamide 9 (76 mg, $16 \%$ yield) as an off-white solid. Spectral data: LCMS: Method 1 (ESI, $\mathrm{m} / \mathrm{z})$ : RT=1.39 $\mathrm{min}, \mathrm{m} / \mathrm{z}=338.1[\mathrm{M}+\mathrm{H}]^{+}(\mathrm{calc} \mathrm{m} / \mathrm{z}=337.2) ;{ }^{1} \mathbf{H}$ NMR $(400$ MHz, methanol-d4) $\delta 8.42$ (dd, $J=3.6,1.2 \mathrm{~Hz}, 1 \mathrm{H}$ ), 7.65 (ddd, $J=7.6,1.7,0.8 \mathrm{~Hz}, 1 \mathrm{H}$ ), 7.24 (dd, $J=7.7,4.8 \mathrm{~Hz}$, 1H), 7.13 (s, $1 \mathrm{H}$ ), 7.11 (d, $J=2.4 \mathrm{~Hz}, 1 \mathrm{H}$ ), 6.86 (ddd, $J=10.0,2.5,1.0 \mathrm{~Hz}, 1 \mathrm{H}), 5.00$ (d, $J=8.7 \mathrm{~Hz}, 1 \mathrm{H}$ ), 2.55 (s, $3 \mathrm{H}), 2.51$ (s, 3H), 1.54-1.52 (m, 1H), 0.69-0.54 (m, 2H), 0.49-0.45 (m, 2H); ${ }^{19}$ F NMR (376 MHz, methanol- $\left.d 4\right) \delta$ 126.1.

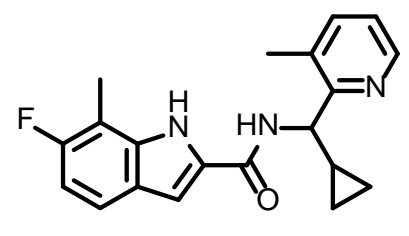

10

mAU

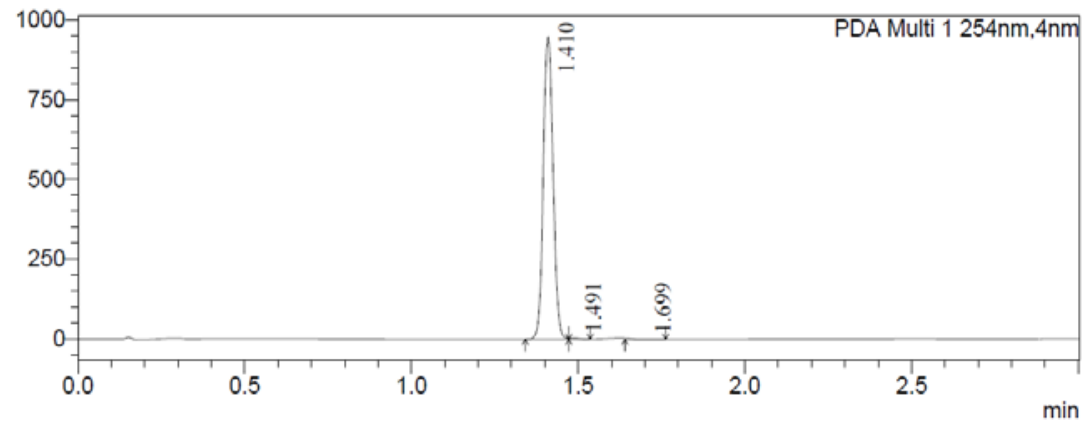

Prepared by using GP1 with 6-fluoro-7-methyl-1H-indole-2-carboxylic acid (200 mg, $1.04 \mathrm{mmol}, 1.0$ equiv) and cyclopropyl(3-methylpyridin-2-yl)methanamine S2 (201 mg, $1.24 \mathrm{mmol}, 1.2$ equiv) resulting in $\mathrm{N}$-(cyclopropyl(3methylpyridin-2-yl)methyl)-6-fluoro-7-methyl-1H-indole-2-carboxamide 10 (76 mg, 16\% yield) as an off-white solid. Spectral data: LCMS: Method 1 (ESI, $\mathrm{m} / \mathrm{z}$ ): RT=1.41 $\mathrm{min}, \mathrm{m} / \mathrm{z}=338.1[\mathrm{M}+\mathrm{H}]^{+}$(calc $\left.\mathrm{m} / \mathrm{z}=337.2\right) ;{ }^{1} \mathbf{H}$ NMR (400 MHz, methanol- $d 4$ ) $\delta 8.42$ (dd, $J=4.8,1.6 \mathrm{~Hz}, 1 \mathrm{H}$ ), 7.55 (ddd, $J=7.7,1.7,0.8 \mathrm{~Hz}, 1 \mathrm{H}$ ), 7.44 (dd, $J=8.7,5.2$ Hz, 1H), 7.24 (dd, $J=7.6,4.8 \mathrm{~Hz}, 1 \mathrm{H}$ ), 7.16 (s, 1H), 6.86 (dd, $J=10.3,8.8 \mathrm{~Hz}, 1 \mathrm{H}$ ), 4.99 (d, $J=8.7 \mathrm{~Hz}, 1 \mathrm{H}), 2.51$ (s, 3H), 2.45 (d, $J=1.7 \mathrm{~Hz}, 3 \mathrm{H}), 1.54-1.50$ (m, 1H), 0.73-0.52 (m, 2H), 0.52-0.42 (m, 2H); ${ }^{19} \mathbf{F}$ NMR (376 MHz, methanol-d4) $\delta$-126.6. 


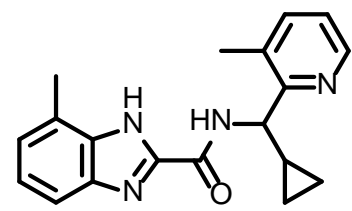

11

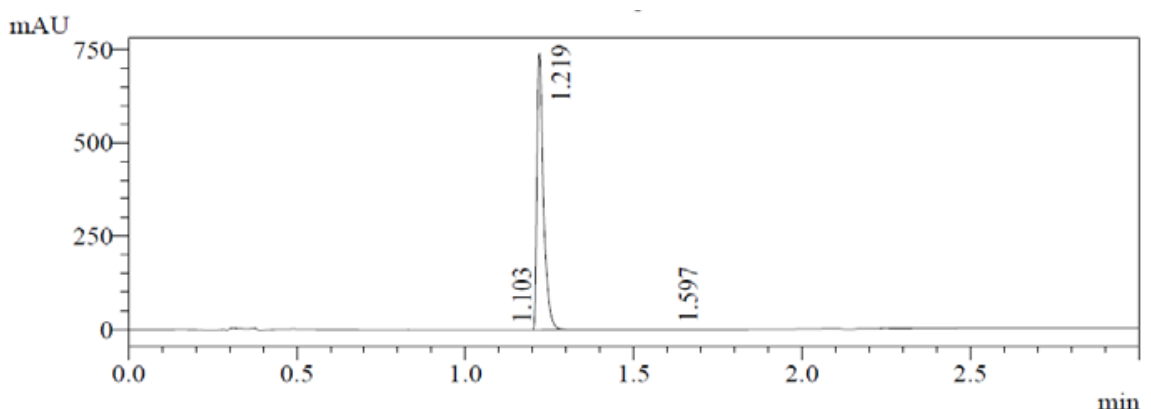

1 PDA Multi $1 / 254 \mathrm{~nm} 4 \mathrm{~nm}$

Prepared by using GP1 with 7-methyl-1H-1,3-benzodiazole-2-carboxylic acid (300 mg, $1.7 \mathrm{mmol}, 1.0$ equiv) and cyclopropyl(3-methylpyridin-2-yl)methanamine*2HCl S2-HCl (518 mg, $2.20 \mathrm{mmol}, 1.3$ equiv) resulting in $N$ (cyclopropyl(3-methylpyridin-2-yl)methyl)-7-methyl-1H-benzo[d]imidazole-2-carboxamide 11 (75 mg, 14\% yield) as a white solid. Spectral data: LCMS: Method 2 (ESI, $\mathrm{m} / \mathrm{z})$ : RT=1.22 $\mathrm{min}, \mathrm{m} / \mathrm{z}=343.10[\mathrm{M}+\mathrm{Na}]^{+}(\mathrm{calc} \mathrm{m} / \mathrm{z}=$ 343.15); ${ }^{1}$ H NMR (400 MHz, methanol- $\left.d 4\right) \delta 8.45$ (dd, $\left.J=4.9,1.6 \mathrm{~Hz}, 1 \mathrm{H}\right), 7.63(\mathrm{dd}, J=8.0,0.8 \mathrm{~Hz}, 1 \mathrm{H}$ ), 7.38 (brs, 1H), 7.24 (m, 2H), 7.13 (brs, 1H), 5.12 (brs, 1H), 2.62 (brs, 3H), 2.49 (s, 3H), 1.54 (s, 1H), 0.63-0.50 (m, 4H).

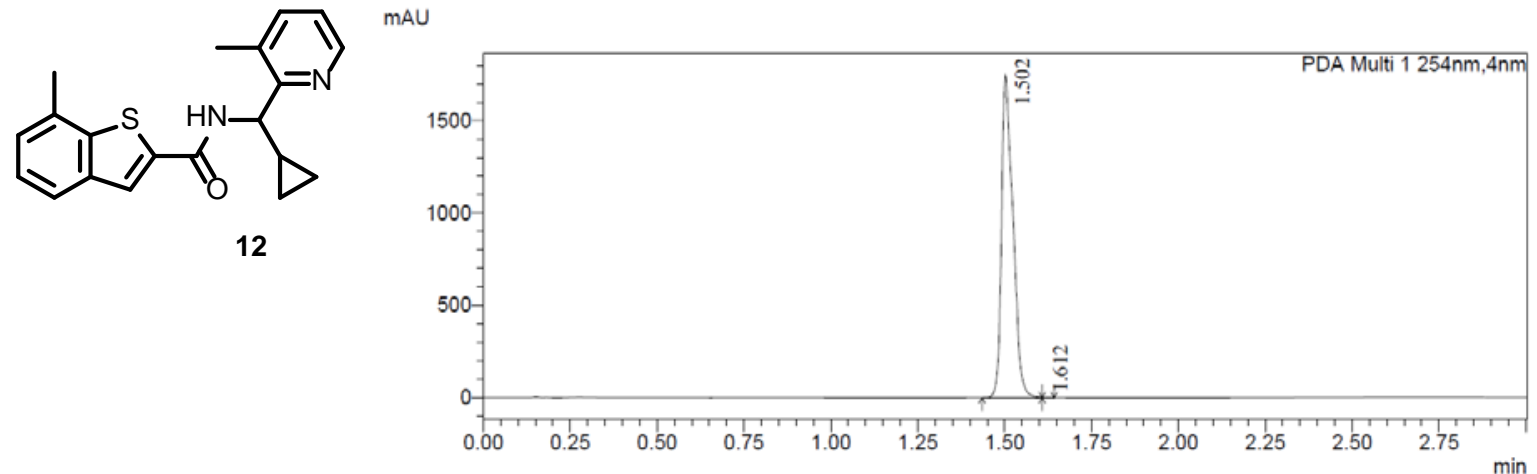

Prepared by using GP1 with 7-methyl-1-benzothiophene-2-carboxylic acid (170 mg, $0.88 \mathrm{mmol}, 1.0$ equiv) and cyclopropyl(3-methylpyridin-2-yl)methanamine S2 (246 mg, $1.52 \mathrm{mmol}, 1.7$ equiv) resulting in $N$-(cyclopropyl(3methylpyridin-2-yl)methyl)-7-methylbenzo[b]thiophene-2-carboxamide 12 (64 mg, 21\% yield) as a white solid. Spectral data: LCMS: Method 1 (ESI, $\mathrm{m} / \mathrm{z})$ : RT=1.50 min, $\mathrm{m} / \mathrm{z}=337.1[\mathrm{M}+\mathrm{H}]^{+}($calc $\mathrm{m} / \mathrm{z}=336.1) ;{ }^{1} \mathbf{H}$ NMR $(400$ MHz, DMSO-d6) $\delta 9.16$ (d, $J=7.8 \mathrm{~Hz}, 1 \mathrm{H}$ ), 8.44 (dd, $J=4.8,1.6 \mathrm{~Hz}, 1 \mathrm{H}), 8.34$ (s, 1H), 7.77 (d, $J=7.9 \mathrm{~Hz}, 1 \mathrm{H}$ ), 7.59 (d, $J=7.8 \mathrm{~Hz}, 1 \mathrm{H}), 7.37$ (t, $J=7.6 \mathrm{~Hz}, 1 \mathrm{H}), 7.28$ (d, $J=7.1 \mathrm{~Hz}, 1 \mathrm{H}), 7.21$ (dd, $J=7.6,4.7 \mathrm{~Hz}, 1 \mathrm{H}$ ), 4.75 (dd, $J$ = 9.0, $7.8 \mathrm{~Hz}, 1 \mathrm{H}), 2.50(\mathrm{~s}, 3 \mathrm{H}), 2.40(\mathrm{~s}, 3 \mathrm{H}), 1.64-1.55(\mathrm{~m}, 1 \mathrm{H}), 1.62-0.31(\mathrm{~m}, 4 \mathrm{H})$.

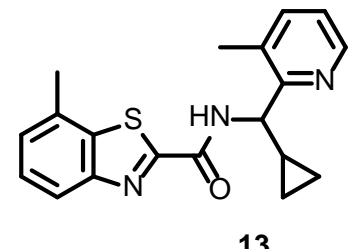

mAU

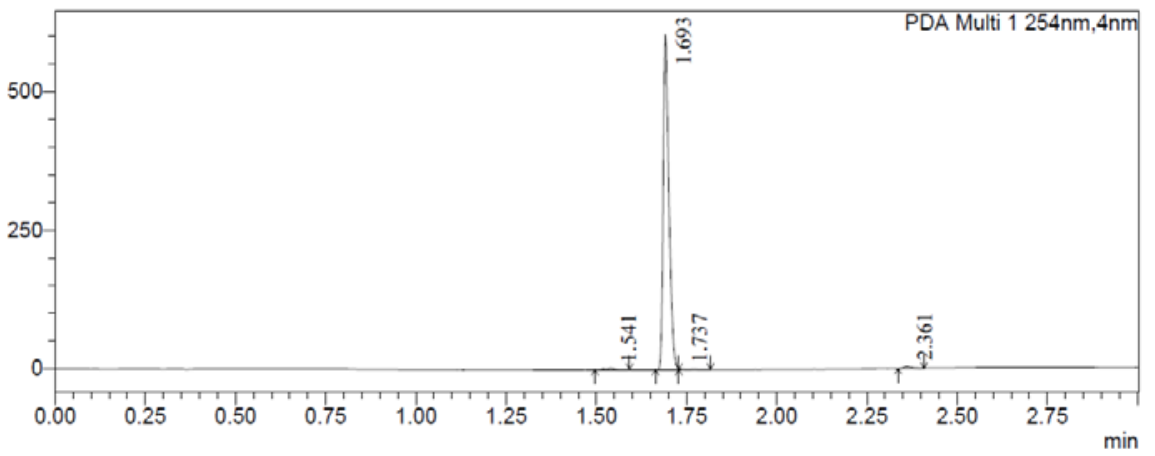


Prepared by using GP1 with 7-methyl-1,3-benzothiazole-2-carboxylic acid (190 mg, $0.98 \mathrm{mmol}, 1.0$ equiv) and cyclopropyl(3-methylpyridin-2-yl)methanamine S2 (160 mg, $0.99 \mathrm{mmol}, 1.0$ equiv) resulting in $N$-(cyclopropyl(3methylpyridin-2-yl)methyl)-7-methylbenzo[d]thiazole-2-carboxamide 13 (83 mg, 25\% yield) as a light yellow solid. Spectral data: LCMS: Method 2 (ESI, $\mathrm{m} / \mathrm{z})$ : RT=1.69 $\mathrm{min}, \mathrm{m} / \mathrm{z}=338.21[\mathrm{M}+\mathrm{H}]^{+}(\mathrm{calc} \mathrm{m} / \mathrm{z}=337.12) ;{ }^{1} \mathbf{H}$ NMR $(400$ MHz, methanol-d4) $\delta 8.46$ (d, $J=4.0 \mathrm{~Hz}, 1 \mathrm{H}), 8.00(\mathrm{~d}, J=8.3 \mathrm{~Hz}, \mathrm{H1}), 7.77$ (d, $J=7.9 \mathrm{~Hz}, 1 \mathrm{H}), 7.54$ (t, $J=7.8 \mathrm{~Hz}$, $1 \mathrm{H}$ ), 7.37 (d, $J=7.3 \mathrm{~Hz}, 1 \mathrm{H}$ ), 7.26 (dd, $J=7.7,4.8 \mathrm{~Hz}, 1 \mathrm{H}), 5.11$ (d, $J=8.2 \mathrm{~Hz}, 1 \mathrm{H}$ ), 2.62 (s, 3H), 2.50 (s, 3H), 1.58-1.50 (m, 1H), 0.67-0.56 (m, 4H).

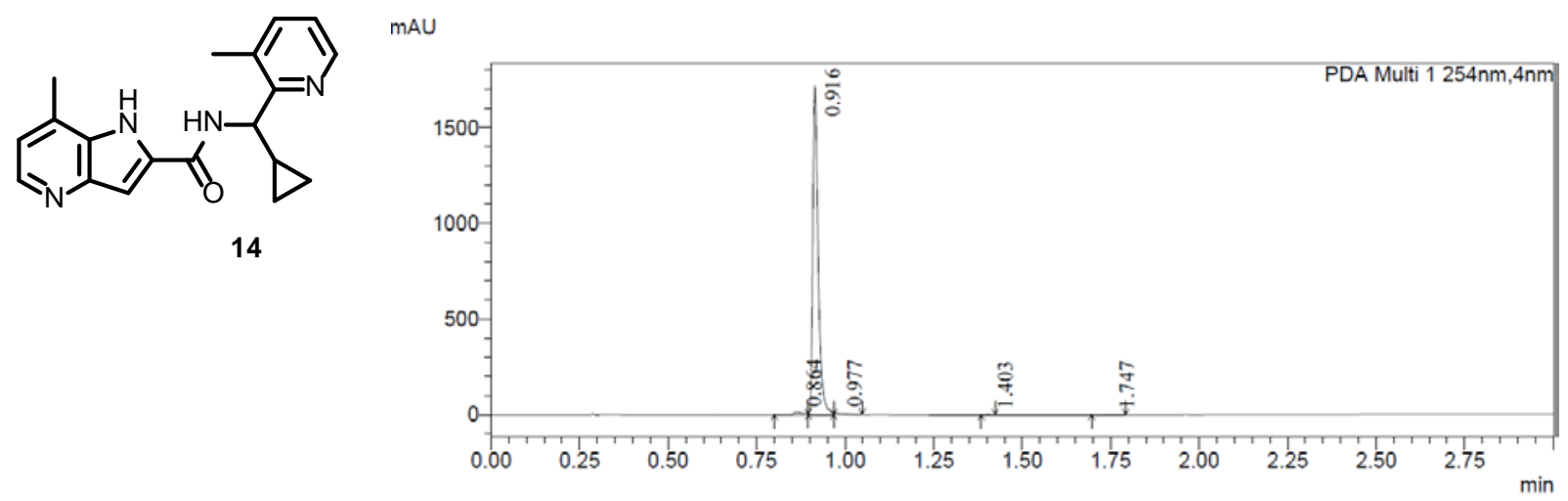

Prepared by using GP1 with 7-methyl-1H-pyrrolo[3,2-b]pyridine-2-carboxylic acid (160 mg, $0.91 \mathrm{mmol}, 1.0$ equiv) and cyclopropyl(3-methylpyridin-2-yl)methanamine S2 (160 mg, $0.99 \mathrm{mmol}, 1.1$ equiv) resulting in $\mathrm{N}$ (cyclopropyl(3-methylpyridin-2-yl)methyl)-7-methyl-1H-pyrrolo[3,2-b]pyridine-2-carboxamide 14 (51 mg, 18\% yield) as a white solid. Prep-HPLC: Kinetex EVO C18 Column, 21.2×150 mm 5 um; ; Mobile Phase A: Water (10 $\mathrm{mmol} / \mathrm{L} \mathrm{NH} \mathrm{HCO}_{3}$ ), Mobile Phase B: MeCN Flow rate: $25 \mathrm{~mL} / \mathrm{min}$; Gradient: $10 \%$ B to $60 \%$ in 9 min, $254 \mathrm{~nm}$; Spectral data: LCMS: Method 2 (ESI, $\mathrm{m} / \mathrm{z}$ ): RT $=0.92 \mathrm{~min}, \mathrm{~m} / \mathrm{z}=321.19[\mathrm{M}+\mathrm{H}]^{+}(\mathrm{calc} \mathrm{m} / \mathrm{z}=320.16) ;{ }^{1} \mathbf{H}$ NMR $(300$ MHz, DMSO-d6) $\delta 11.72$ (s, 1H), 9.04 (d, $J=7.8 \mathrm{~Hz}, 1 \mathrm{H}$ ), 8.44 (d, $J=3.3 \mathrm{~Hz}, 1 \mathrm{H}), 8.24$ (d, $J=4.5 \mathrm{~Hz}, 1 \mathrm{H}), 7.58$ (d, $J=7.2 \mathrm{~Hz}, 1 \mathrm{H}$ ), 7.34 (s, 1H), 7.21 (dd, $J=7.2,4.8 \mathrm{~Hz}, 1 \mathrm{H}$ ), 7.00 (d, $J=4.2 \mathrm{~Hz}, 1 \mathrm{H}$ ), 4.80 (t, $J=8.5 \mathrm{~Hz}, 1 \mathrm{H}$ ), 2.51 (d, $J=6.3 \mathrm{~Hz}, 3 \mathrm{H}$ ), 2.42 (s, 3H), 1.64-1.61 (m, 1H), 0.60-0.35 (m, 4H).

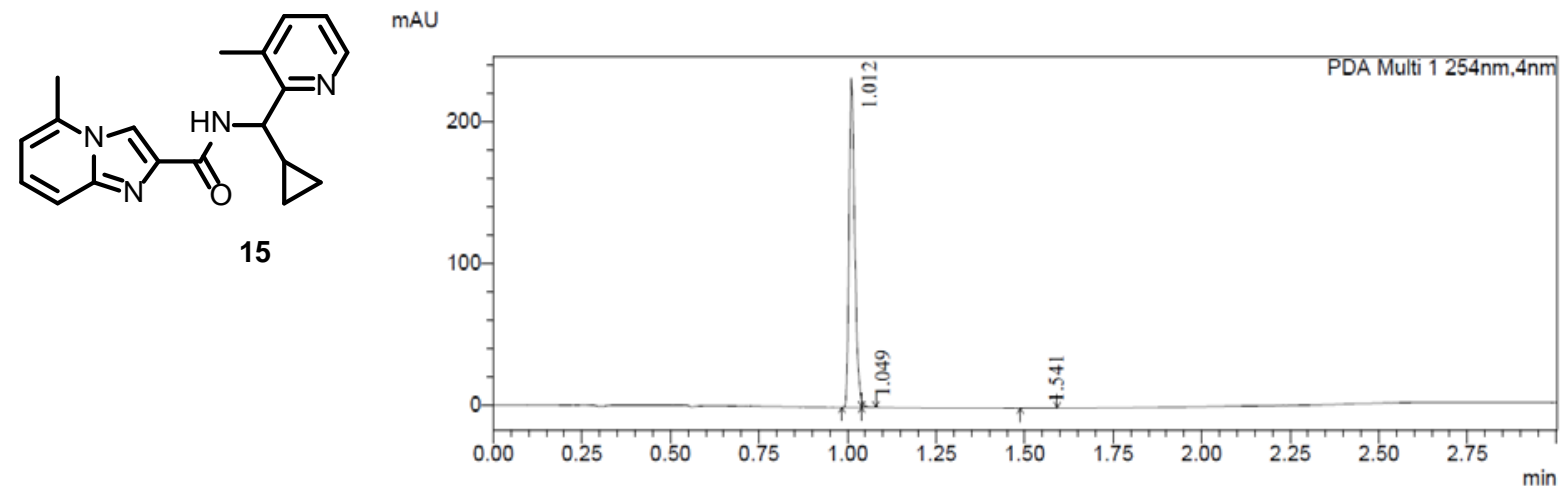

Prepared by using GP1 with 7-methylimidazo[1,2-a]pyridine-2-carboxylic acid (150 mg, $0.85 \mathrm{mmol}, 1.0$ equiv) and cyclopropyl(3-methylpyridin-2-yl)methanamine*2HCl S2-HCl (219 mg, $0.92 \mathrm{mmol}, 1.1$ equiv) resulting in $N$ (cyclopropyl(3-methylpyridin-2-yl)methyl)-5-methylimidazo[1,2-a]pyridine-2-carboxamide 15 (57 mg, 21\% yield) as a white solid. Spectral data: LCMS: Method 2 (ESI, $\mathrm{m} / \mathrm{z}): \mathrm{RT}=1.01 \mathrm{~min}, \mathrm{~m} / \mathrm{z}=321.20[\mathrm{M}+\mathrm{H}]^{+}(\mathrm{calc} \mathrm{m} / \mathrm{z}=$ 320.16); ${ }^{1} \mathbf{H}$ NMR (400 MHz, methanol-d4) $\delta 8.43$ (d, $\left.J=4.9 \mathrm{~Hz}, 1 \mathrm{H}\right), 8.19$ (s, 1H), 7.63 (dd, $J=7.6,0.8 \mathrm{~Hz}, 1 \mathrm{H}$ ), 7.52 (d, $J=9.2 \mathrm{~Hz}, 1 \mathrm{H}$ ), 7.35 (dd, $J=9.2,6.9 \mathrm{~Hz}, 1 \mathrm{H}$ ), 7.22 (dd, $J=7.7,4.8 \mathrm{~Hz}, 1 \mathrm{H}$ ), 6.83 (d, $J=6.8 \mathrm{~Hz}, 1 \mathrm{H}), 5.16$ (d, $J=8.0 \mathrm{~Hz}, 1 \mathrm{H}), 2.66$ (s, 3H), 2.50 (s, 3H), 1.54-1.49 (m, 1H), 0.61-0.44 (m, 4H). 
Overview for Table 2 Analogs: Compounds containing an aryl central core were prepared using a variant of the route shown in Supplementary Scheme S3. Compound $\mathbf{1 6}$ was prepared using the commercially available S3 building block.<smiles>[R]c1cc(N)cc(N(C)CC)c1</smiles><smiles>[R]c1ccc(C)c2[nH]c(C(=O)O)cc12</smiles>

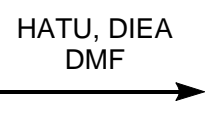<smiles></smiles><smiles>Nc1ccccc1N1CCOCC1</smiles><smiles>Cc1cccc2cc(C(=O)O)[nH]c12</smiles>
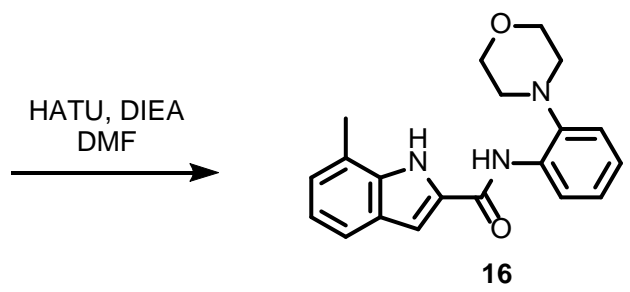

Supplementary Scheme S3: Preparation of analogs in Table 2.

General reaction procedure (GP2): To a reaction vessel containing the appropriate carboxylic acid (1.0 equiv), $N$ ethyl- $N$-isopropylpropan-2-amine (5.0 equiv), and the substituted aniline partner (1.5 equiv) in DMF (5 mL) was added HATU $\left(0.46 \mathrm{mmol}, 1.3\right.$ equiv) at $21^{\circ} \mathrm{C}$. The reaction mixture was aged for $18 \mathrm{~h}$ with stirring, at which time the reaction was shown to be complete by TLC. The product mixture was then diluted with deionized water $(10 \mathrm{~mL})$ and transferred to a separatory funnel containing ethyl acetate $(25 \mathrm{~mL})$. The layers were separated, and the aqueous layer was re-extracted with additional ethyl acetate $(2 \times 25 \mathrm{~mL})$. The organic layers were combined and dried over magnesium sulfate. The dried solution was filtered through a plug of celite and the filtrate was concentrated under reduced pressure (12 mbar). The residue was purified by Prep-HPLC with the following conditions: Column: XBridge Prep OBD C18 Column, 30×150 mm 5 um; Mobile Phase A: Water (10 mmol/L NH $4 \mathrm{HCO}_{3}$ ), Mobile Phase B: MeCN; Flow rate: $10 \mathrm{~mL} / \mathrm{min}$; Gradient: 35 B to 65 B in $7 \mathrm{~min} ; 254 \mathrm{~nm}$.

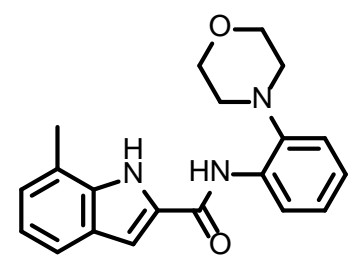

16

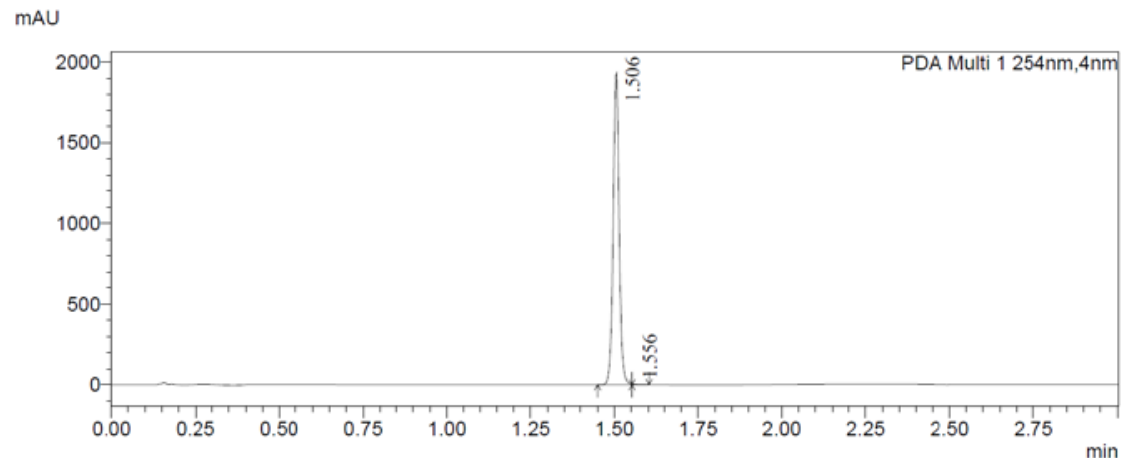

Prepared by using GP2 with 7-methyl- $1 H$-indole-2-carboxylic acid (100 mg, $0.57 \mathrm{mmol}, 1.0$ equiv) and 3(morpholin-4-yl)aniline (153 mg, $0.86 \mathrm{mmol}, 1.5$ equiv) resulting in 7-methyl- $N$-(3-morpholinophenyl)- $1 H$-indole2-carboxamide 17 (92 mg, 48\% yield) as a white solid. Prep-HPLC: Xselect CSH F-Phenyl OBD Column, 19×150 mm 5 um; Mobile Phase A: Water (0.05\% TFA), Mobile Phase B: MeCN Flow rate: 25 mL/min; Gradient: 40\% B to 83\% in $7 \mathrm{~min}, 254 \mathrm{~nm}$; Spectral data: LCMS: Method 2 (ESI, m/z): RT=1.64 min, m/z =336.10 [M +H] ${ }^{+}(\mathrm{calc} \mathrm{m} / \mathrm{z}$ = 335.16); ${ }^{1} \mathbf{H}$ NMR (400 MHz, methanol-d4) $\delta$ 8.23-8.20 (m, 1H), 7.53 (d, J=8.0 Hz, 1H), 7.31-7.29 (m, $\left.1 \mathrm{H}\right), 7.18$ (m, 3H), 7.05 (m, 2H), 3.92 (t, $J=4.8 \mathrm{~Hz}, 4 \mathrm{H}), 2.95$ (t, $J=4.8 \mathrm{~Hz}, 4 \mathrm{H}), 2.59$ (s, 3H). 


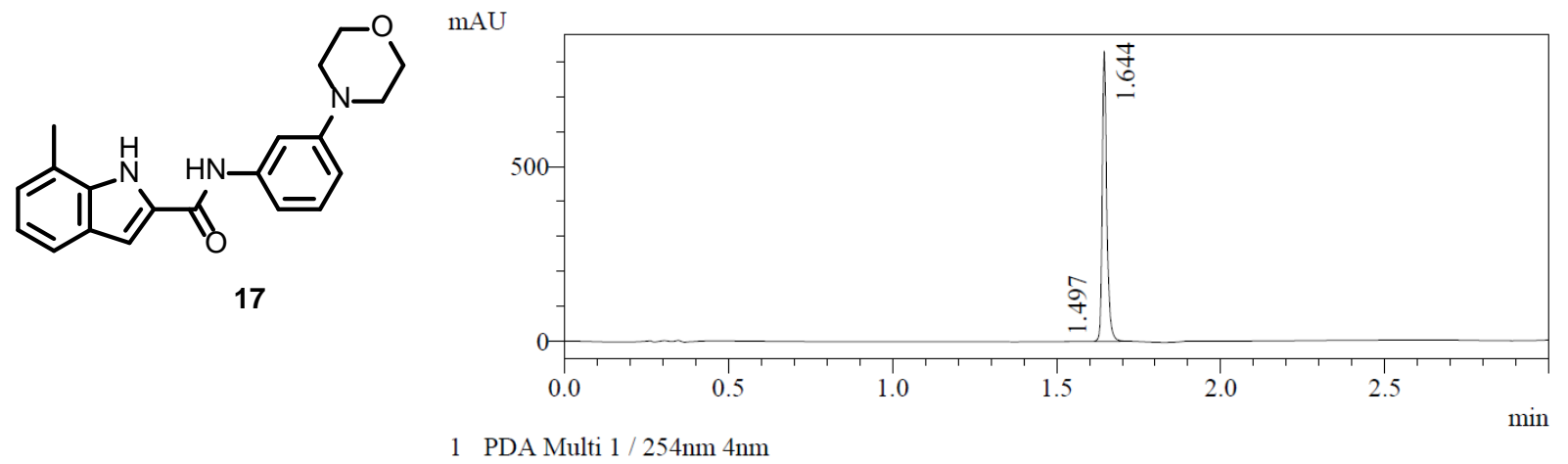

Prepared by using GP2 with 7-methyl-1H-indole-2-carboxylic acid (100 mg, $0.57 \mathrm{mmol}, 1.0$ equiv) and 3(morpholin-4-yl)aniline (153 mg, $0.86 \mathrm{mmol}, 1.5$ equiv) resulting in 7-methyl- $N$-(3-morpholinophenyl)- $1 \mathrm{H}$-indole2-carboxamide 17 (92 mg, 48\% yield) as a white solid. Prep-HPLC: Xselect CSH F-Phenyl OBD Column, 19×150 mm 5 um; Mobile Phase A: Water (0.05\% TFA), Mobile Phase B: MeCN Flow rate: 25 mL/min; Gradient: 40\% B to 83\% in $7 \mathrm{~min}, 254 \mathrm{~nm}$; Spectral data: LCMS: Method 2 (ESI, $\mathrm{m} / \mathrm{z}$ ): RT=1.64 min, $\mathrm{m} / \mathrm{z}=336.10[\mathrm{M}+\mathrm{H}]^{+}(\mathrm{calc} \mathrm{m} / \mathrm{z}$ $=335.16$ ); ${ }^{1} \mathbf{H}$ NMR (400 MHz, DMSO-d6) $\delta 11.53$ (s, 1H), 10.06 (s, 1H), 7.50 (d, $\left.J=7.6 \mathrm{~Hz}, 1 \mathrm{H}\right), 7.43$ (t, $J=2.2$ $\mathrm{Hz}, 1 \mathrm{H}), 7.39$ (d, $J=2.1 \mathrm{~Hz}, 1 \mathrm{H}), 7.35-7.33(\mathrm{~m}, 1 \mathrm{H}), 7.22$ (t, $J=8.1 \mathrm{~Hz}, 1 \mathrm{H}), 7.00(\mathrm{~m}, 2 \mathrm{H}), 6.74-6.72(\mathrm{~m}, 1 \mathrm{H})$, 3.77 (m, 4H), 3.12 (t, $J=4.8 \mathrm{~Hz}, 4 \mathrm{H}), 2.54$ (s, 3H).

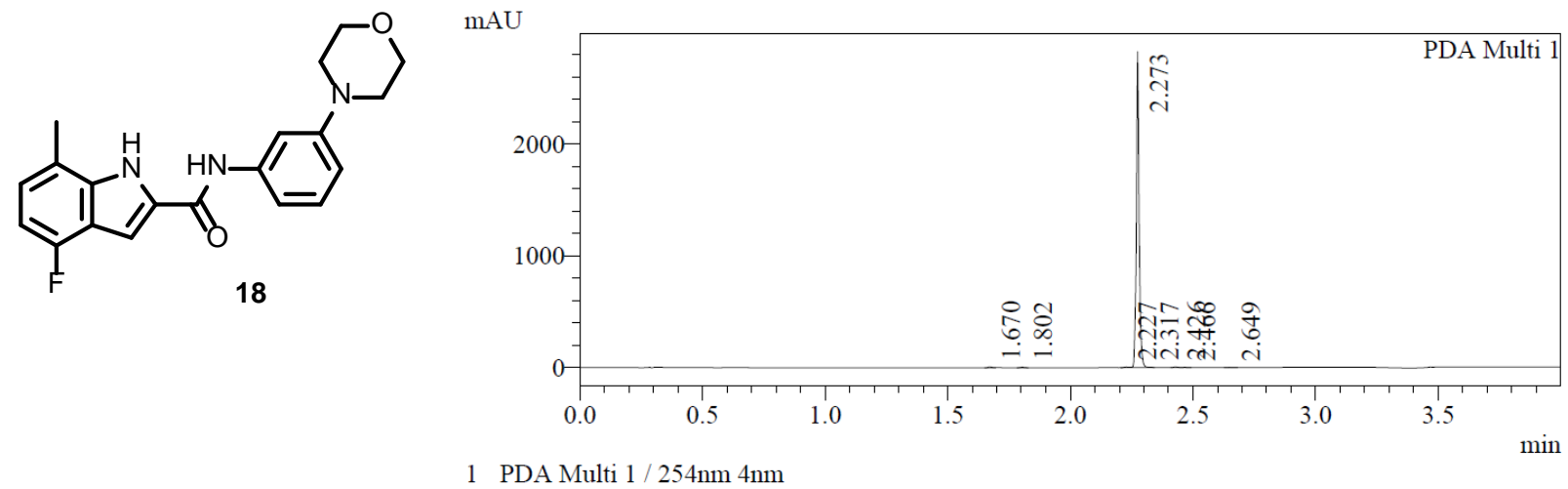

Prepared by using GP2 with 4-flouro-7-methyl- $1 H$-indole-2-carboxylic acid 36 (120 mg, $0.62 \mathrm{mmol}, 1.0$ equiv) and 3-(morpholin-4-yl)aniline (120 mg, $0.67 \mathrm{mmol}, 1.1$ equiv) resulting in 4-fluoro-7-methyl- $\mathrm{N}$-(3-morpholinophenyl)$1 \mathrm{H}$-indole-2-carboxamide 18 (41 mg, 19\% yield) as a white solid. Spectral data: LCMS: Method 2 (ESI, $\mathrm{m} / \mathrm{z}$ ): RT=1.64 min, $m / z=354.10[\mathrm{M}+\mathrm{H}]^{+}$(calc $\left.\mathrm{m} / \mathrm{z}=353.15\right) ;{ }^{1} \mathbf{H}$ NMR $(400 \mathrm{MHz}$, methanol- $d 4) \delta$ 7.43-7.42 $(\mathrm{m}, 1 \mathrm{H})$, 7.38 (s, 1H), 7.27-7.22 (m, 2H), 6.99-6.96 (m, 1H), 6.82-6.79 (m, 1H), 6.67 (dd, $J=10.8,8.0 \mathrm{~Hz}, 1 \mathrm{H}), 3.85$ (m, 4H), 3.18 (m, 4H), 2.52 (s, 3H); ${ }^{19}$ F NMR (282 MHz, methanol-d4) $\delta$-127.9. 

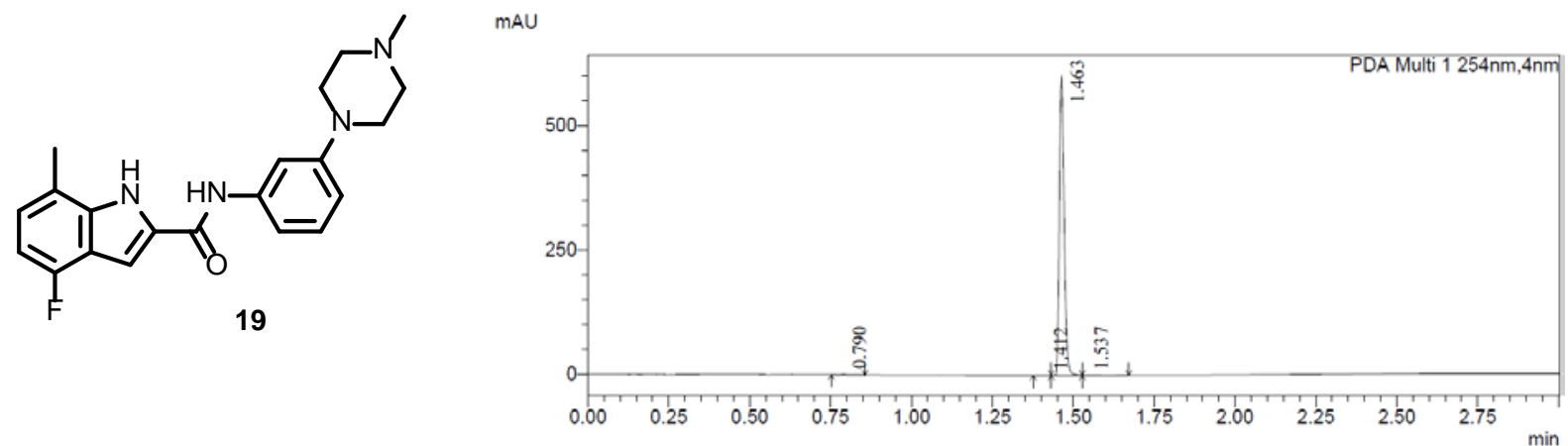

Prepared by using GP2 with 4-flouro-7-methyl- $1 \mathrm{H}$-indole-2-carboxylic acid 36 (200 mg, $1.05 \mathrm{mmol}$, 1.0 equiv) and 3-(4-methylpiperazin-1-yl)aniline (200 mg, $1.05 \mathrm{mmol}, 1.1$ equiv) resulting in 4-fluoro-7-methyl- $\mathrm{N}$-(3-(4methylpiperazin-1-yl)phenyl)-1H-indole-2-carboxamide 19 (74 mg, 20\% yield) as a white solid. Spectral data: LCMS: Method 2 (ESI, $\mathrm{m} / \mathrm{z}$ ): RT=1.64 min, $\mathrm{m} / \mathrm{z}=367.21[\mathrm{M}+\mathrm{H}]^{+}(\mathrm{calc} \mathrm{m} / \mathrm{z}=366.19) ;{ }^{1} \mathbf{H} \mathrm{NMR}(300 \mathrm{MHz}$, methanol-d4) $\delta 7.45$ (br s, H1), 7.40 (s, 1H), 7.29-7.23 (m, 2H), 7.02-6.97 (m, 1H), 6.84-6.78 (m, 1H), 6.69 (dd, $\mathrm{J}=$ 10.2, $8.0 \mathrm{~Hz}, 1 \mathrm{H}), 3.27$ (m, 4H), 2.66 (m, 4H), 2.54 (s, 3H), 2.38 (s, 3H); ${ }^{19}$ F NMR (376 MHz, methanol-d4) $\delta$ 127.9 .

Compound 20 was initially prepared using the following route:
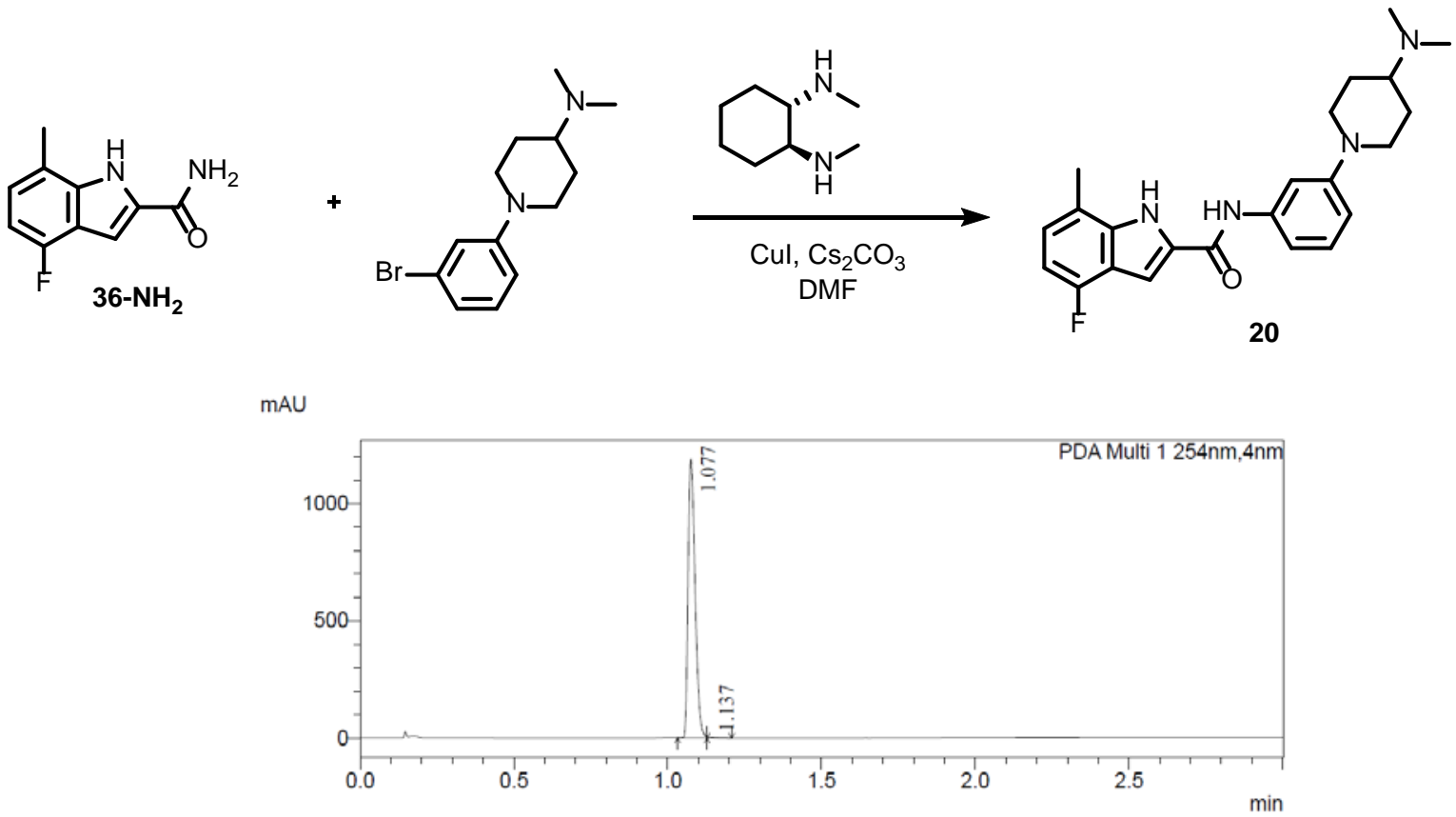

Using the following procedure: 1-(3-Bromophenyl)- $N, N$-dimethylpiperdin-4-amine (200 mg, $0.71 \mathrm{mmol}, 1.0 \mathrm{equiv}$ ), (1S,2S)-1- $N, 2-N$-dimethylcyclohexane-1,2-diamine (250 mg, $1.76 \mathrm{mmol}, 2.5$ equiv), copper iodide (270 mg, 1.42 mmol, 2.0 equiv) and cesium carbonate (600 mg, 2.0 equiv) were added to dry DMF ( $3 \mathrm{~mL}$ ) under an atmosphere of nitrogen. The mixture stirred for 10 minutes and then 4-flouro-7-methyl- $1 \mathrm{H}$-indole-2-carboxamide $\mathbf{3 6}-\mathbf{N H}_{\mathbf{2}}$ (200 mg, $1.05 \mathrm{mmol}, 1.5$ equiv) was added. The reaction mixture was aged for $3 \mathrm{~h}$ with stirring at $100{ }^{\circ} \mathrm{C}$, at which time the reaction was shown to be complete by TLC. The product mixture was then diluted with deionized water $(20 \mathrm{~mL})$ and transferred to a separatory funnel containing ethyl acetate $(15 \mathrm{~mL})$. The layers were separated, and the aqueous layer was re-extracted with additional ethyl acetate $(2 \times 15 \mathrm{~mL})$. The organic layers were combined and dried over magnesium sulfate. The dried solution was filtered through a plug of celite and the filtrate was concentrated under 
reduced pressure (12 mbar). The residue obtained was purified by purified by Prep-HPLC with the following conditions: Column: XBridge Prep OBD C18 Column, 30×150 mm 5 um; Mobile Phase A: Water $(10 \mathrm{mmol} / \mathrm{L}$ $\mathrm{NH}_{4} \mathrm{HCO}_{3}$ ), Mobile Phase B: MeCN; Flow rate: $10 \mathrm{~mL} / \mathrm{min}$; Gradient: 35 B to $65 \mathrm{~B}$ in $7 \mathrm{~min} ; 254 \mathrm{~nm}$ to afford $N$ (3-(4-(dimethylamino)piperidin-1-yl)phenyl)-4-fluoro-7-methyl-1 $H$-indole-2-carboxamide 20 (36 mg,13\% yield) as a white solid. Spectral data: LCMS: Method 2 (ESI, $\mathrm{m} / \mathrm{z}$ ): RT=1.08 min, $\mathrm{m} / \mathrm{z}=395.21[\mathrm{M}+\mathrm{H}]^{+}$(calc $\mathrm{m} / \mathrm{z}=394.22$ ); ${ }^{1} \mathbf{H}$ NMR (400 MHz, methanol-d4) $\delta 7.46$ (br s, $1 \mathrm{H}$ ), 7.40 (s, 1H), 7.27-7.23 (m, 2H), 7.01-6.98 (m, 1H), 6.83-6.81 (m, 1H), 6.70 (dd, $J=10.4,8.0 \mathrm{~Hz}, 1 \mathrm{H}$ ), 3.83 (d, $J=12.0 \mathrm{~Hz}, 2 \mathrm{H}), 2.77$ (t, $J=12.0 \mathrm{~Hz}, 2 \mathrm{H}), 2.54$ (s, 3H), 2.37 (m, 7H), 2.02 (m, 2H), 1.66 (m, 2H); ${ }^{19}$ F NMR (376 MHz, methanol-d4) $\delta$-127.9.

The aryl central core for 21-23 was prepared via the route shown in Supplementary Scheme S4. 3,5-Disubstitutednitrobenzene S5/S8/S11 was reacted with the $N, N$-dimethylpiperdin-4-amine to provide the displacement product S6/S9/S12. Reduction of the nitro group was accomplished by either $\mathrm{Fe} / \mathrm{H}^{+}$or $\mathrm{Pd} / \mathrm{C}$ in the presence of hydrogen gas.
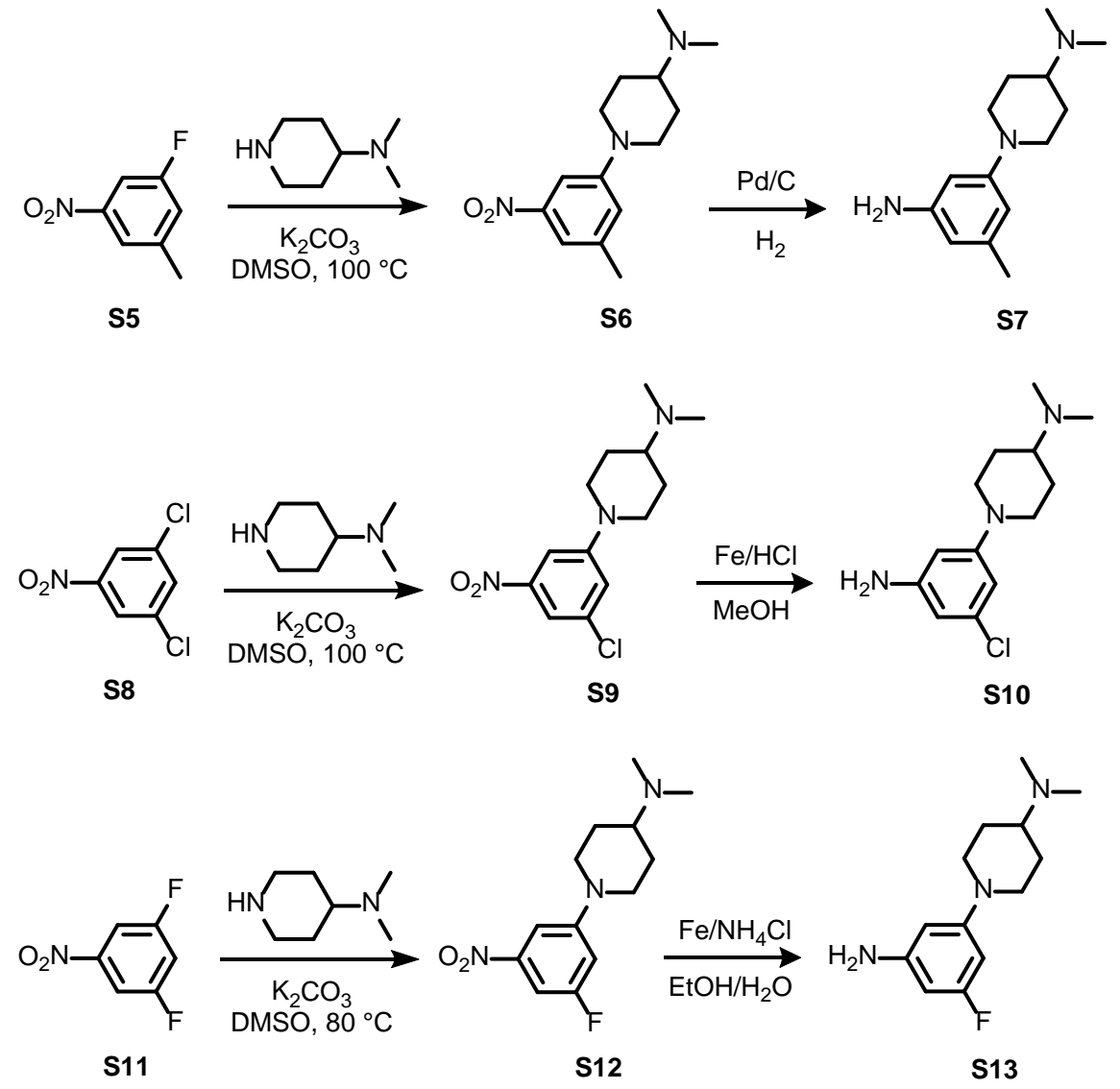

Supplementary Scheme S4: Preparation of the aryl central core for 21-23.

Preparation of S7: 1-Fluoro-3-methyl-5-nitrobenzene S5 (500 mg, $3.22 \mathrm{mmol}, 1.0$ equiv), $N, N$-dimethylpiperdin-4amine (413 mg, $3.22 \mathrm{mmol}, 1.0$ equiv) and potassium carbonate ( $890 \mathrm{mg}, 6.44 \mathrm{mmol}, 2.0$ equiv) were added to dry DMSO ( $5 \mathrm{~mL}$ ) under an atmosphere of nitrogen. The reaction mixture was aged for 3 hours with stirring at $100{ }^{\circ} \mathrm{C}$, at which time the reaction was shown to be complete by TLC. The product mixture was then diluted with aqueous sodium chloride solution $(50 \mathrm{~mL})$ and transferred to a separatory funnel containing ethyl acetate $(50 \mathrm{~mL})$. The layers were separated, and the aqueous layer was re-extracted with additional ethyl acetate ( 3 x $50 \mathrm{~mL}$ ). The organic layers were combined and dried over sodium sulfate. The dried solution was filtered through a plug of celite and the filtrate was concentrated under reduced pressure (12 mbar) furnishing $N, N$-dimethyl-1-(3-methyl-5-nitrophenyl)piperidin-4- 
amine S6 (200 mg, 24\% yield) as a yellow solid. LCMS: Method 3 (ESI, $\mathrm{m} / \mathrm{z}$ ): RT=0.57 $\mathrm{min}, \mathrm{m} / \mathrm{z}=264.2[\mathrm{M}+\mathrm{H}]^{+}$ (calc $m / z=263.2$ ).

A 2-neck reaction vessel was charged with $N, N$-dimethyl-1-(3-methyl-5-nitrophenyl)piperidin-4-amine $\mathbf{S 6}$ (200 mg, $0.76 \mathrm{mmol}, 1$ equiv), $\mathrm{Pd} / \mathrm{C}$ ( $80 \mathrm{mg}$ ), and $\mathrm{MeOH}(4 \mathrm{~mL})$. The solids were stirred for 1 minute and the vessel was evacuated and backfilled with nitrogen (x3). Then a balloon of hydrogen gas was attached to the reaction vessel with an adapter that allowed for the balloon to be closed off to the reaction flask. With the hydrogen balloon closed off, the reaction vessel was evacuated and then the balloon was opened to the reaction vessel (x2). After 1 hour, the flask was evacuated and filled with nitrogen, and the solids were filtered through a plug of celite and the filtrate was concentrated under reduced pressure (12 mbar) furnishing 1-(3-amino-5-methylphenyl)- $N$, $N$-dimethylpiperidin-4amine S7 (140 mg, 79\%) as a colorless oil. . LCMS: Method 3 (ESI, $\mathrm{m} / \mathrm{z}$ ): RT=0.13 min, $\mathrm{m} / \mathrm{z}=234.2[\mathrm{M}+\mathrm{H}]^{+}$(calc $m / z=233.2)$.

Preparation of S10: 1,3-dichloro-5-nitrobenzene $\mathbf{S 8}$ (500 mg, $2.6 \mathrm{mmol}, 1.0$ equiv), $N, N$-dimethylpiperdin-4-amine $(5 \mathrm{~mL})$ and potassium carbonate $(710 \mathrm{mg}, 5.14 \mathrm{mmol}, 1.0$ equiv) were added to dry DMSO (5 mL) under an atmosphere of nitrogen. The reaction mixture was aged for 3 hours with stirring at $100{ }^{\circ} \mathrm{C}$, at which time the reaction was shown to be complete by TLC. The product mixture was then diluted with aqueous sodium chloride solution (50 $\mathrm{mL})$ and transferred to a separatory funnel containing ethyl acetate $(50 \mathrm{~mL})$. The layers were separated, and the aqueous layer was re-extracted with additional ethyl acetate $(3 \times 50 \mathrm{~mL})$. The organic layers were combined and dried over sodium sulfate. The dried solution was filtered through a plug of celite and the filtrate was concentrated under reduced pressure (12 mbar) furnishing $N, N$-dimethyl-1-(3-chloro-5-nitrophenyl)piperidin-4-amine S9 (600 mg, 81\% yield) as a red oil. LCMS: Method 3 (ESI, $\mathrm{m} / \mathrm{z}$ ): RT=1.08 min, $\mathrm{m} / \mathrm{z}=284.6[\mathrm{M}+\mathrm{H}]^{+}$(calc $\mathrm{m} / \mathrm{z}=283.1$ ).

1-(3-Chloro-5-nitrophenyl)- $N, N$-dimethylpiperidin-4-amine $\mathbf{S 9}$ (500 mg, 1.76 mmol, 1.0 equiv) and Fe fillings (989 mg, 10.00 equiv) were added to a reaction vessel containing aqueous $\mathrm{HCl}(1 \mathrm{~mL})$ and methanol (10 $\mathrm{mL}$ ), and the resulting solution was stirred for at $21{ }^{\circ} \mathrm{C}$. After the reaction had aged for 2 hours, the product mixture was filtrated and concentrated under reduced pressure (12 mbar). The product residue was purified by reverse flash chromatography (C18 silica gel; mobile phase, MeCN in water, 0\% to 100\% gradient in 30 min; detector, UV 254 $\mathrm{nm}$ ) furnishing1-(3-amino-5-chlorophenyl)- $N, N$-dimethylpiperidin-4-amine $\mathbf{S 1 0}$ (450 $\mathrm{mg}, 80 \%$ yield) as a red solid. LCMS: Method 1 (ESI, $\mathrm{m} / \mathrm{z})$ : RT=0.82 $\mathrm{min}, \mathrm{m} / \mathrm{z}=254.0[\mathrm{M}+\mathrm{H}]^{+}($calc $\mathrm{m} / \mathrm{z}=253.1)$.

Preparation of S13: 1,3-Difluoro-5-nitrobenzene S11 (2.0 g, 12.6 mmol, 1.0 equiv), $N, N$-dimethylpiperdin-4-amine (1.6 g, $12.5 \mathrm{mmol}, 1.0$ equiv) and potassium carbonate (1.7 g mg, $12.3 \mathrm{mmol}, 1.0$ equiv) were added to dry DMSO $(9 \mathrm{~mL})$ under an atmosphere of nitrogen. The reaction mixture was aged for 2.5 hours with stirring at $80{ }^{\circ} \mathrm{C}$, at which time the reaction was shown to be complete by TLC. The product mixture was then diluted with aqueous sodium chloride solution $(50 \mathrm{~mL})$ and transferred to a separatory funnel containing ethyl acetate $(50 \mathrm{~mL})$. The layers were separated, and the aqueous layer was re-extracted with additional ethyl acetate ( $3 \times 50 \mathrm{~mL}$ ). The organic layers were combined and dried over sodium sulfate. The dried solution was filtered through a plug of celite and the filtrate was concentrated under reduced pressure (12 mbar) furnishing1-(3-fluoro-5-nitrophenyl)- $N, N$-dimethylpiperidin-4amine S12 (2.5 g, 74\% yield) as a yellow solid. LCMS: Method 4 (ESI, $\mathrm{m} / \mathrm{z}$ ): RT=055 min, $\mathrm{m} / \mathrm{z}=267.8[\mathrm{M}+\mathrm{H}]^{+}$ (calc $m / z=267.1$ ).

1-(3-Fluoro-5-nitrophenyl)- $N, N$-dimethylpiperidin-4-amine S12 (700 mg, $2.62 \mathrm{mmol}, 1.0$ equiv) and Fe fillings (734 mg, 5.0 equiv) were added to a reaction vessel containing aqueous ammonium chloride (695 mg, 13.0 mmol, 5.0 equiv in $2 \mathrm{~mL}$ of water) and ethanol $(8 \mathrm{~mL})$, and the resulting solution was stirred for at $80{ }^{\circ} \mathrm{C}$. After the reaction had aged for 2 hours, the product mixture was filtrated and concentrated under reduced pressure (12 mbar). The product residue was purified by reverse flash chromatography (IntelFlash-1 Column, C18 silica gel; mobile phase, MeCN/ water =0-100\%; Detector, UV $254 \mathrm{~nm}$ ) furnishing 1-(3-amino-5-fluorophenyl)- $N, N$ dimethylpiperidin-4-amine S13 (300 mg, 48\% yield) as a brown solid. LCMS: Method 1 (ESI, m/z): RT=0.72 min, $\mathrm{m} / \mathrm{z}=238.0[\mathrm{M}+\mathrm{H}]^{+}($calc $\mathrm{m} / \mathrm{z}=237.2)$. 


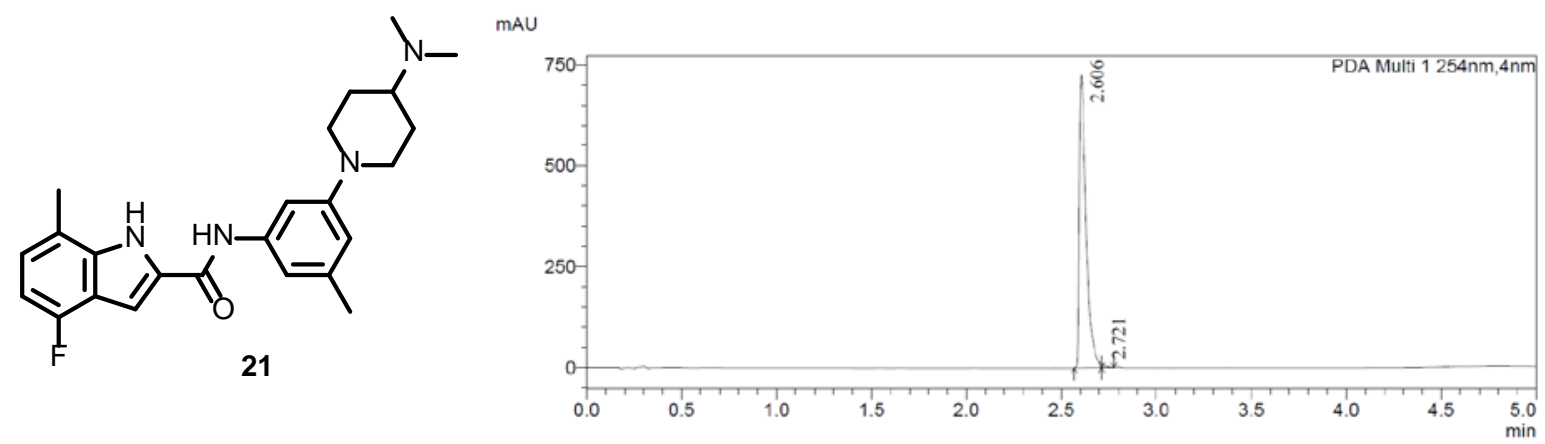

Prepared by using GP2 with 4-flouro-7-methyl-1H-indole-2-carboxylic acid 36 (100 mg, $0.52 \mathrm{mmol}, 1.0$ equiv) and 1-(3-amino-5-methylphenyl)- $N, N$-dimethylpiperidin-4-amine S7 (120 mg, $0.51 \mathrm{mmol}, 1.00$ equiv) resulting in $N$-[3[4-(dimethylamino)piperidin-1-yl]-5-methylphenyl]-4-fluoro-7-methyl-1H-indole-2-carboxamide 21 (58 mg, 28\% yield) as a white solid. Spectral data: LCMS: Method 2 (ESI, $\mathrm{m} / \mathrm{z})$ : RT=2.61 min, $\mathrm{m} / \mathrm{z}=409.2[\mathrm{M}+\mathrm{H}]^{+}(\mathrm{calc} \mathrm{m} / \mathrm{z}=$ 408.2); ${ }^{1}$ H NMR (300 MHz, methanol- $\left.d 4\right) \delta 7.40$ (s, $\left.1 \mathrm{H}\right), 7.26(\mathrm{~s}, 1 \mathrm{H}), 7.05$ (d, $\left.J=3.3 \mathrm{~Hz}, 2 \mathrm{H}\right), 6.69$ - 6.66 (m, 2H), 3.79 (d, $J=2.1 \mathrm{~Hz}, 2 \mathrm{H}), 2.72-2.69$ (m, 2H), 2.54 (s, 3H), 2.34 (s, 10H), 1.99 (d, $J=2.1 \mathrm{~Hz}, 2 \mathrm{H}), 1.79-1.58$ (m, 2H); ${ }^{19}$ F NMR (282 MHz, methanol-d4) $\delta$-127.8.
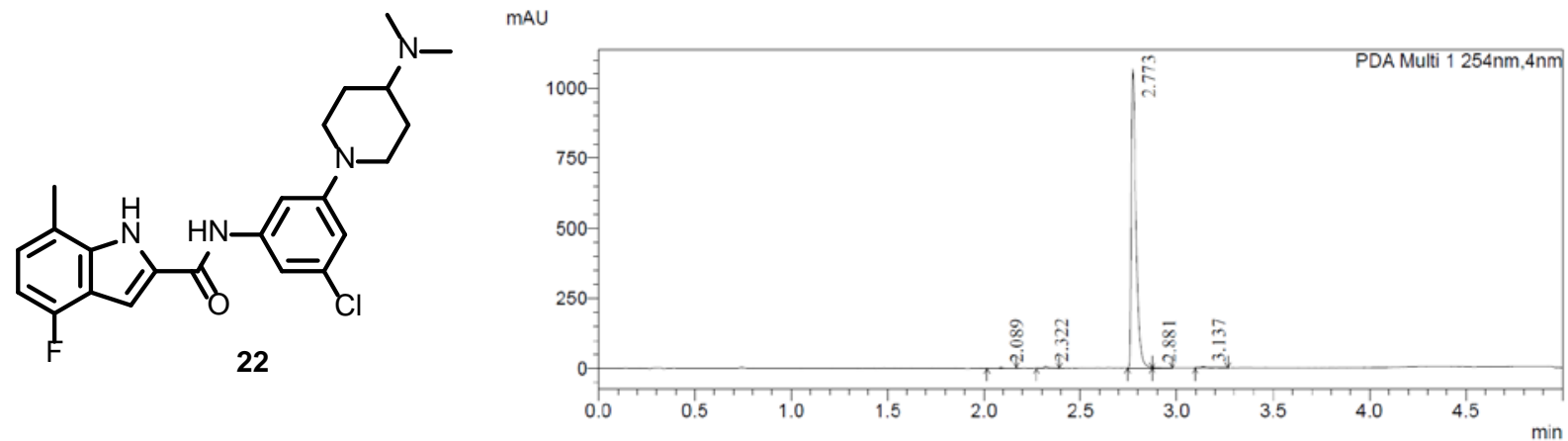

Prepared by using GP2 with 4-flouro-7-methyl- $1 \mathrm{H}$-indole-2-carboxylic acid 36 (150 mg, $0.78 \mathrm{mmol}, 1.0$ equiv) and 1-(3-amino-5-chlorophenyl)- $N, N$-dimethylpiperidin-4-amine (200 mg, $0.79 \mathrm{mmol}, 1.0$ equiv) $\mathbf{S 1 0}$ (185 mg, 0.78 mmol, 1.0 equiv) resulting in $N$-[3-chloro-5-[4-(dimethylamino)piperidin-1-yl]phenyl]-4-fluoro-7-methyl- $1 \mathrm{H}$ indole-2-carboxamide 22 (28 mg, 8\% yield) as a white solid. Spectral data: LCMS: Method 2 (ESI, m/z): RT=2.77 min, $m / z=429.2[\mathrm{M}+\mathrm{H}]^{+}$(calc $\left.\mathrm{m} / \mathrm{z}=428.2\right) ;{ }^{1} \mathbf{H}$ NMR $(300 \mathrm{MHz}$, methanol- $d 4) \delta 7.42(\mathrm{~s}, 1 \mathrm{H}), 7.38(\mathrm{t}, J=1.8 \mathrm{~Hz}$, $1 \mathrm{H}), 7.33$ (t, $J=1.8 \mathrm{~Hz}, 1 \mathrm{H}), 7.03-6.98(\mathrm{~m}, 1 \mathrm{H}), 6.78(\mathrm{t}, J=1.8 \mathrm{~Hz}, 1 \mathrm{H}), 6.70$ (dd, $J=10.4,7.8 \mathrm{~Hz}, 1 \mathrm{H}), 3.85$ (d, $J$ $=13.3 \mathrm{~Hz}, 2 \mathrm{H}), 2.80(\mathrm{t}, J=12.7 \mathrm{~Hz}, 2 \mathrm{H}), 2.55(\mathrm{~s}, 3 \mathrm{H}), 2.38(\mathrm{~m}, 7 \mathrm{H}), 2.06-2.01(\mathrm{~m}, 2 \mathrm{H}), 1.67-1.61(\mathrm{~m}, 2 \mathrm{H}) . ;{ }^{19} \mathbf{F}$ NMR (282 MHz, methanol- $d 4) \delta-127.8$.
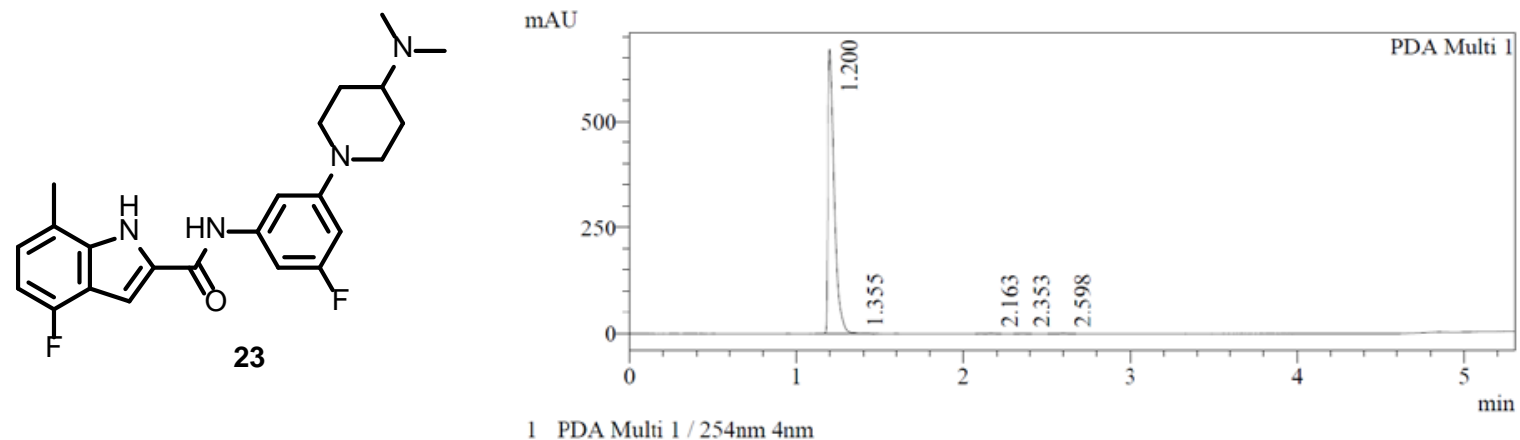
Prepared by using GP2 with 4-flouro-7-methyl- $1 H$-indole-2-carboxylic acid 36 (150 mg, $0.78 \mathrm{mmol}, 1.0$ equiv) and 1-(3-amino-5-fluorophenyl)- $N, N$-dimethylpiperidin-4-amine $\mathbf{S 1 3}$ (185 mg, $0.78 \mathrm{mmol}, 1.0$ equiv) resulting in $N$-[3[4-(dimethylamino)piperidin-1-yl]-5-fluorophenyl]-4-fluoro-7-methyl-1H-indole-2-carboxamide 23 (41 mg, 19\% yield) as a white solid. Spectral data: LCMS: Method 2 (ESI, $\mathrm{m} / \mathrm{z})$ : RT=1.20 min, $\mathrm{m} / \mathrm{z}=413.0[\mathrm{M}+\mathrm{H}]^{+}($calc $\mathrm{m} / \mathrm{z}=$ 412.2); ${ }^{1} \mathbf{H}$ NMR (300 MHz, methanol-d4) $\delta 7.41$ (s, $\left.1 \mathrm{H}\right), 7.15$ (m, 2H), 7.04-6.96 (m, 1H), 6.70 (dd, $J=10.3,7.9$ Hz, 1H), 6.51 (dt, $J=12.2,2.2 \mathrm{~Hz}, 1 \mathrm{H}), 3.84$ (d, $J=12.8 \mathrm{~Hz}, 2 \mathrm{H}), 2.78(\mathrm{t}, J=12.7 \mathrm{~Hz}, 2 \mathrm{H}), 2.54(\mathrm{~s}, 3 \mathrm{H}), 2.36(\mathrm{~m}$, $7 \mathrm{H}), 2.00(\mathrm{~d}, J=12.7 \mathrm{~Hz}, 2 \mathrm{H}), 1.61$ (qd, $J=12.3,4.0 \mathrm{~Hz}, 2 \mathrm{H}) ;{ }^{19}$ F NMR (282 MHz, methanol-d4) $\delta$-113.9, -127.8.

The aryl central core for $\mathbf{2 4}$ and $\mathbf{2 5}$ is prepared via the route shown in Supplementary Scheme S5. 3-bromonitrobenzene S14 was coupled via a Pd-catalyzed Buchwald reaction with the $N$-Boc-protected aminopyrrolidine to provide S15. Elaboration of the terminal amine by removal of the $N$-Boc protecting group followed by acetylation provided the fully elaborated substituted nitrobenzene S16. Reduction of the nitro group with $\mathrm{Fe} / \mathrm{H}^{+}$furnished S17. 3,5-Difluoro-nitrobenzene $\mathbf{S 1 8}$ was reacted with the $N$-Boc-protected aminopyrrolidine to provide the displacement product S19. Elaboration of the terminal amine by removal of the $N$-Boc protecting group followed by acetylation provided the fully elaborated substituted nitrobenzene S20. Reduction of the nitro group with $\mathrm{Pd} / \mathrm{C}$ in the presence of hydrogen gas furnished S21.

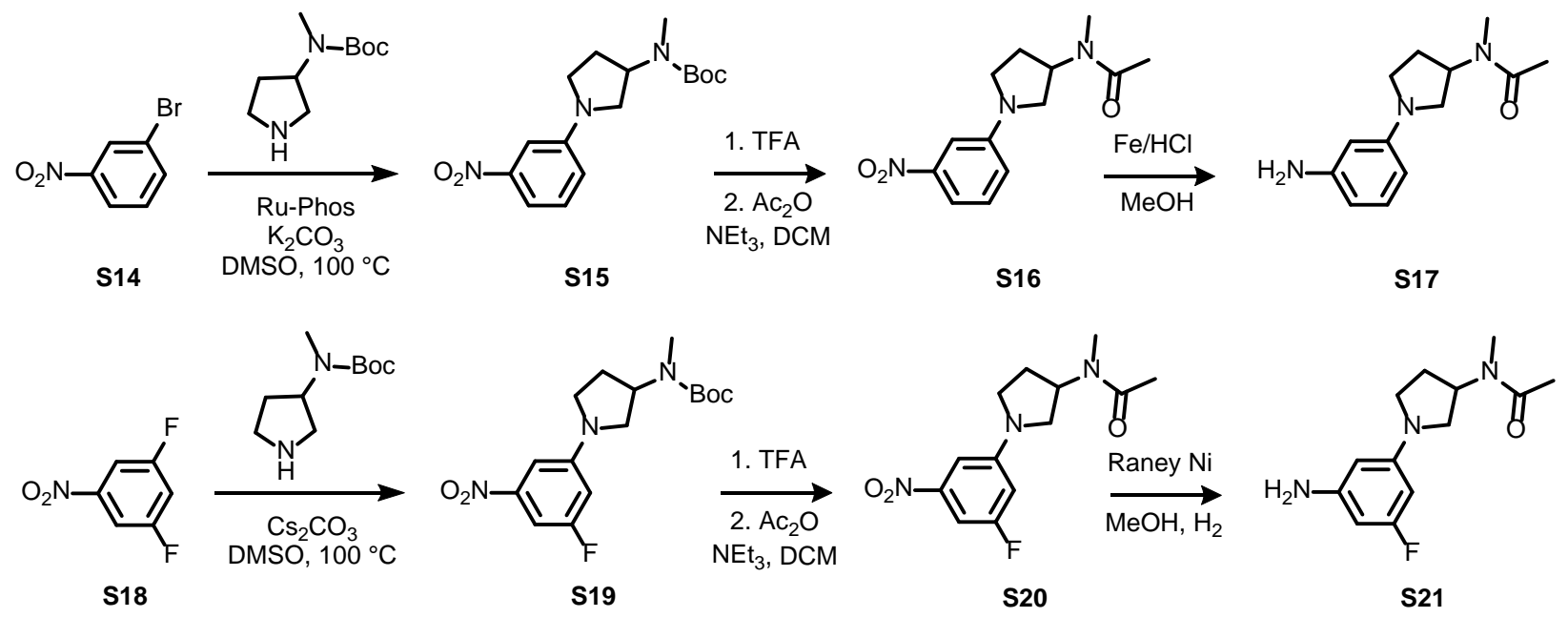

Supplementary Scheme S5: Preparation of the aryl central core for 24 and 25.

Preparation of S17: 1-Bromo-3-nitrobenzene S14 (500 mg, $2.48 \mathrm{mmol}, 1.0$ equiv), potassium carbonate (680 mg, $4.92 \mathrm{mmol}, 2.0$ equiv), tert-butyl pyrrolidine-3-yl $N$-methylcarbamate (590 mg, $2.93 \mathrm{mmol}, 1.2$ equiv), and Ru-Phos (600 mg, 1.0 equiv) were added to dry DMSO $(5 \mathrm{~mL})$ under an atmosphere of nitrogen. The reaction mixture was aged for $2 \mathrm{~h}$ with stirring at $100{ }^{\circ} \mathrm{C}$, at which time the reaction was shown to be complete by TLC. The product mixture was then diluted with aqueous sodium chloride solution $(5 \mathrm{~mL})$ and transferred to a separatory funnel containing ethyl acetate $(50 \mathrm{~mL})$ and additional aqueous sodium chloride $(45 \mathrm{~mL})$. The layers were separated, and the aqueous layer was re-extracted with additional ethyl acetate $(3 \times 50 \mathrm{~mL})$. The organic layers were combined and dried over sodium sulfate. The dried solution was filtered through a plug of celite and the filtrate was concentrated under reduced pressure (12 mbar) furnishing tert-butyl 1-(3-nitrophenyl)pyrrolidine-3-yl $N$-methylcarbamate S15 (500 mg, 63\% yield) as a yellow solid. LCMS: Method 4 (ESI, $\mathrm{m} / \mathrm{z}): \mathrm{RT}=1.16 \mathrm{~min}, \mathrm{~m} / \mathrm{z}=322.2[\mathrm{M}+\mathrm{H}]^{+}(\mathrm{calc} \mathrm{m} / \mathrm{z}=$ 321.2).

Tert-butyl $N$-methyl- $N$-[1-(3-nitrophenyl)pyrrolidin-3-yl]carbamate S15 (200 mg, 0.62 mmol, 1.00 equiv) was added to a reaction vessel containing trifluoroacetic acid $(2 \mathrm{~mL})$ and dichloromethane $(5 \mathrm{~mL})$. The resulting solution was aged for 2 hours with stirring at $21{ }^{\circ} \mathrm{C}$ at which time the resulting product mixture was concentrated under reduced pressure (12 mbar) furnishing $N$-methyl-1-(3-nitrophenyl)pyrrolidin-3-amine (150 mg, crude) as a white solid. LCMS: Method 1 (ESI, $\mathrm{m} / \mathrm{z}$ ): RT=0.83 min, $\mathrm{m} / \mathrm{z}=222.2[\mathrm{M}+\mathrm{H}]^{+}$(calc $\mathrm{m} / \mathrm{z}=221.1$ ). $N$-Methyl-1-(3- 
nitrophenyl)pyrrolidin-3-amine (500 mg, $2.26 \mathrm{mmol}, 1.0$ equiv), acetic anhydride ( $2 \mathrm{~mL})$, and triethylamine (2 mL) were added to dry dichloromethane $(5 \mathrm{~mL})$. After the reaction mixture aged for 2 hours with stirring, the product mixture was concentrated under reduced pressure (12 mbar) furnishing $N$-methyl- $N$-[1-(3-nitrophenyl)pyrrolidine-3yl]acetamide S16 (450 mg crude, 76\% yield) as a white solid. LCMS: Method 2 (ESI, $\mathrm{m} / \mathrm{z}$ ): RT=0.92 min, $\mathrm{m} / \mathrm{z}$ $=264.0[\mathrm{M}+\mathrm{H}]^{+}($calc $\mathrm{m} / \mathrm{z}=263.1)$.

$N$-Methyl- $N$-[1-(3-nitrophenyl)pyrrolidin-3-yl]acetamide (20 mg, $0.08 \mathrm{mmol}, 1.00$ equiv) and Fe fillings (42 mg, 10.00 equiv) were added to a reaction vessel containing aqueous $\mathrm{HCl}(0.5 \mathrm{~mL})$ and methanol $(1 \mathrm{~mL})$, and the resulting solution was stirred for at $21^{\circ} \mathrm{C}$. After the reaction had aged for 2 hours, the product mixture was filtrated and concentrated under reduced pressure (12 mbar). The product residue was purified by reverse flash chromatography (C18 silica gel; mobile phase, MeCN in water, 0\% to 100\% gradient in 30 min; detector, UV 254 $\mathrm{nm}$ ) furnishing $N$-[1-(3-aminophenyl)pyrrolidin-3-yl]- $N$-methylacetamide $\mathbf{S 1 7}$ (15 mg, 85\% yield) as a white solid. LCMS: Method 2 (ESI, $m / z)$ : RT=0.80 min, $m / z=233.95[M+H]^{+}($calc $m / z=233.15$ ).

Preparation of S21: 1,3-Difluoro-5-nitrobenzene S18 (2 g, 12.6 mmol, 1.0 equiv), cesium carbonate (13 g, 39.9 mmol, 3.2 equiv), and tert-butyl pyrrolidine-3-yl $N$-methylcarbamate (2.6 g, $12.0 \mathrm{mmol}, 1.03$ equiv) were added to dry DMSO $(30 \mathrm{~mL})$ under an atmosphere of nitrogen. The reaction mixture was aged for $2 \mathrm{~h}$ with stirring at $100{ }^{\circ} \mathrm{C}$, at which time the reaction was shown to be complete by TLC. The product mixture was then diluted with aqueous sodium chloride solution $(50 \mathrm{~mL})$ and transferred to a separatory funnel containing ethyl acetate $(50 \mathrm{~mL})$ and additional aqueous sodium chloride $(50 \mathrm{~mL})$. The layers were separated, and the aqueous layer was re-extracted with additional ethyl acetate $(3 \times 50 \mathrm{~mL})$. The organic layers were combined and dried over sodium sulfate. The dried solution was filtered through a plug of celite and the filtrate was concentrated under reduced pressure (12 mbar). The residue was purified via flash chromatography (silica; EtOAc/PE 50/50), collected fractions combined, and concentrated under reduced pressure (12 mbar) furnishing tert-butyl $N$-[1-(3-fluoro-5-nitrophenyl)pyrrolidin-3-yl]$\mathrm{N}$-methylcarbamate S19 (680 mg, 16\% yield) as a light yellow solid. LCMS: Method 2 (ESI, $\mathrm{m} / \mathrm{z}$ ): RT=1.49 min, $m / z=340.1[\mathrm{M}+\mathrm{H}]^{+}($calc $m / z=339.2)$.

Tert-butyl $N$-[1-(3-fluoro-5-nitrophenyl)pyrrolidin-3-yl]- $N$-methylcarbamate S19 (650 mg, 1.92 mmol, 1.00 equiv) was added to a reaction vessel containing trifluoroacetic acid $(3 \mathrm{~mL})$ and dichloromethane $(7 \mathrm{~mL})$. The resulting solution was aged for 1 hour with stirring at $21^{\circ} \mathrm{C}$ at which time the resulting product mixture was concentrated under reduced pressure (12 mbar) furnishing 1-(3-fluoro-5-nitrophenyl)- $N$-methylpyrrolidin-3-amine (350 mg, crude) as a light yellow solid. LCMS: Method 2 (ESI, $\mathrm{m} / \mathrm{z}$ ): RT=0.92 $\mathrm{min}, \mathrm{m} / \mathrm{z}=239.75[\mathrm{M}+\mathrm{H}]^{+}$(calc $\mathrm{m} / \mathrm{z}$ = 239.1). 1-(3-fluoro-5-nitrophenyl)- $N$-methylpyrrolidin-3-amine ( $1.0 \mathrm{~g}, 4.18 \mathrm{mmol}, 1.0$ equiv), acetic anhydride (2 $\mathrm{mL})$, and triethylamine $(2 \mathrm{~mL})$ were added to dry dichloromethane $(10 \mathrm{~mL})$. After the reaction mixture aged for 2 hours with stirring, the product mixture was concentrated under reduced pressure (12 mbar). The product residue was purified by flash chromatography (silica; EtOAc/PE 50/50) furnishing $N$-[1-(3-fluoro-5-nitrophenyl)pyrrolidin3-yl]- $N$-methylacetamide S20 (900 mg, 77\% yield) as a white solid. LCMS: Method 2 (ESI, $\mathrm{m} / \mathrm{z}$ ): RT=1.20 min, $\mathrm{m} / \mathrm{z}=281.65[\mathrm{M}+\mathrm{H}]^{+}($calc $\mathrm{m} / \mathrm{z}=281.12)$.

$N$-[1-(3-Fluoro-5-nitrophenyl)pyrrolidin-3-yl]- $N$-methylacetamide S20 (300 mg, 1.07 mmol, 1.00 equiv) and Raney $\mathrm{Ni}(300 \mathrm{mg}$ ) were added to a reaction vessel containing methanol $(10 \mathrm{~mL})$. Hydrogen gas was introduced into the reaction vessel and the resulting solution was stirred for at $21{ }^{\circ} \mathrm{C}$. After the reaction had aged for 1 hour, the product mixture was filtrated and concentrated under reduced pressure (12 mbar) furnishing N-[1-(3-amino-5fluorophenyl)pyrrolidin-3-yl]-N-methylacetamide S21 (220 mg, 82\% yield) as an off-white solid. LCMS: Method 2 (ESI, $\mathrm{m} / \mathrm{z}$ ): RT=0.85 $\mathrm{min}, \mathrm{m} / \mathrm{z}=251.85[\mathrm{M}+\mathrm{H}]^{+}($calc $\mathrm{m} / \mathrm{z}=251.14)$. 

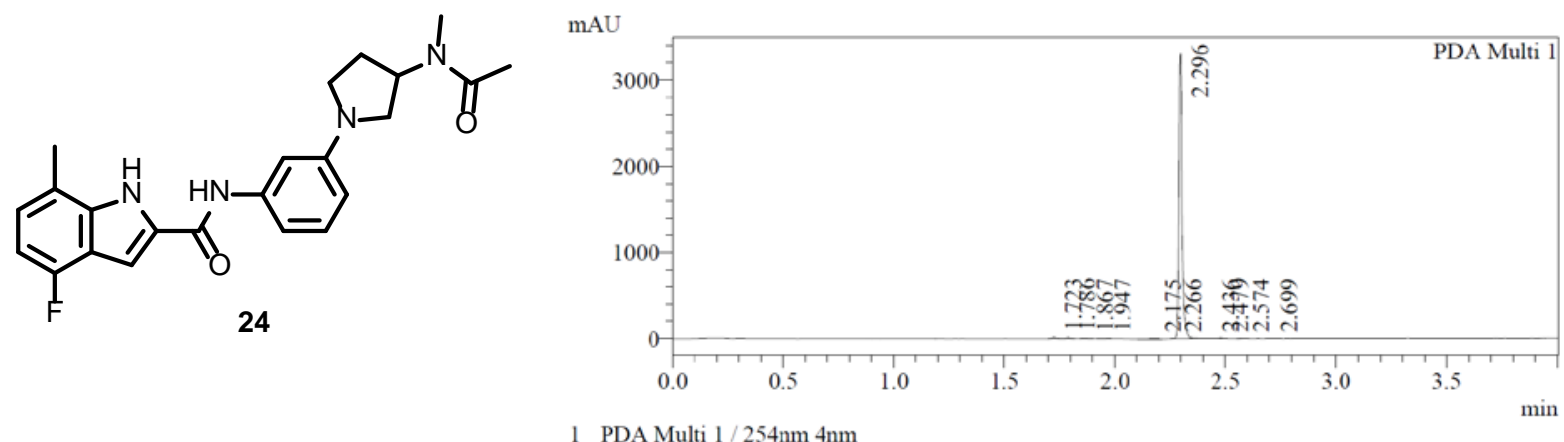

Prepared by using GP2 with 4-flouro-7-methyl-1H-indole-2-carboxylic acid 36 (165 mg, 0.85 mmol, 1.0 equiv) and $N$-[1-(3-aminophenyl)pyrrolidin-3-yl]- $N$-methylacetamide S17 (200 mg, 0.86 mmol, 1.0 equiv) resulting in 4-fluoro7-methyl- $N$-[3-[3-( $N$-methylacetamido)pyrrolidin-1-yl]phenyl]-1H-indole-2-carboxamide 24 (111 mg, $32 \%$ yield) as a white solid. Spectral data: LCMS: Method 2 (ESI, m/z): RT=2.30 min, $\mathrm{m} / \mathrm{z}=430.95[\mathrm{M}+\mathrm{Na}]^{+}(\mathrm{calc} \mathrm{m} / \mathrm{z}=431.19)$; ${ }^{1}$ H NMR (300 MHz, methanol-d4) $\delta 7.40$ (s, 1H), 7.28 - 7.10 (m, 2H), $7.10-7.00$ (m, 2H), 6.99 (d, $J=5.6$ Hz, $1 \mathrm{H}), 6.70-6.60(\mathrm{~m}, 1 \mathrm{H}), 5.38-5.28(\mathrm{~m}, 1 \mathrm{H}), 3.59-3.50(\mathrm{~m}, 1 \mathrm{H}), 3.50-3.40(\mathrm{~m}, 1 \mathrm{H}), 3.40-3.25(\mathrm{~m}, 1 \mathrm{H}), 3.04(\mathrm{~s}$, 2H), 2.92 (s, 1H), 2.55 (d, $J=1.1 \mathrm{~Hz}, 3 \mathrm{H}), 2.38-3.26(\mathrm{~m}, 1 \mathrm{H}), 2.25$ (s, 2H), $2.16(\mathrm{~s}, 2 \mathrm{H}) ;{ }^{19} \mathbf{F}$ NMR (376 MHz, methanol-d4) $\delta-127.9$.
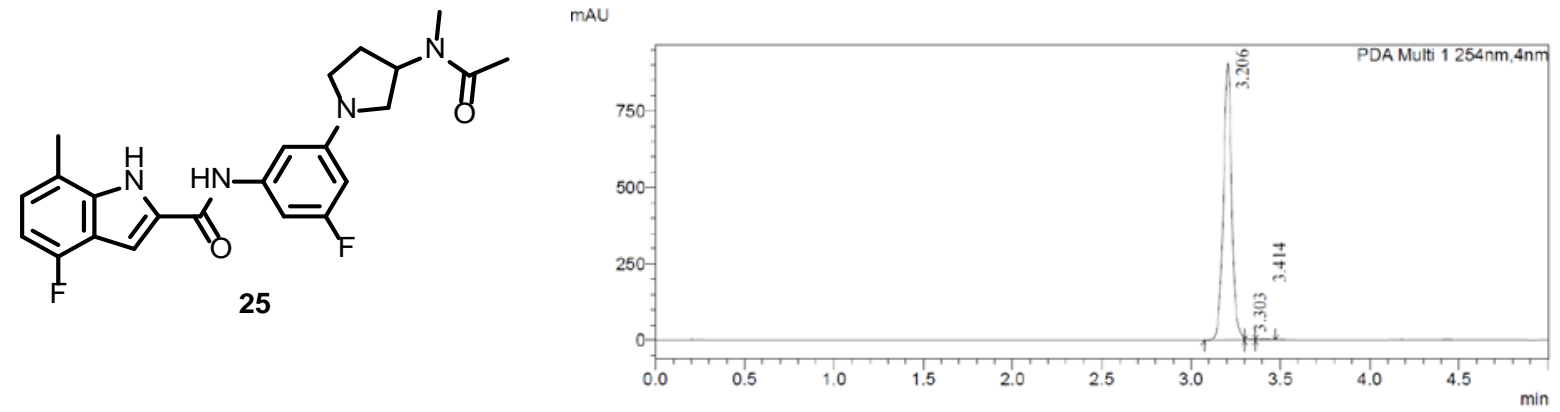

Prepared by using GP2 with 4-flouro-7-methyl-1H-indole-2-carboxylic acid 36 (250 mg, 1.29 mmol, 1.0 equiv) and $N$-[1-(3-amino-5-fluorophenyl)pyrrolidin-3-yl]- $N$-methylacetamide S21 (330 mg, $1.31 \mathrm{mmol}, 1.00$ equiv) resulting 4-fluoro- $N$-[3-fluoro-5-[3-( $N$-methylacetamido)pyrrolidin-1-yl]phenyl]-7-methyl-1H-indole-2-carboxamide 25 (47 mg, 8\% yield) as a light yellow solid. Spectral data: LCMS: Method 1 (ESI, m/z): RT=3.21 min, $\mathrm{m} / \mathrm{z}=426.95$ [M $+\mathrm{H}]^{+}($calc $m / z=426.19) ;{ }^{1} \mathbf{H}$ NMR (400 MHz, DMSO-d6) $\delta 11.92$ (s, 1H), 10.19 (s, 1H), 7.51 (d, $\left.J=1.5 \mathrm{~Hz}, 1 \mathrm{H}\right)$, $7.19-7.08$ (m, 1H), 7.03 - 6.93 (m, 1H), 6.87 (d, J = 2.1 Hz, 1H), $6.82-6.72$ (m, 1H), $6.23-6.10$ (m, $1 \mathrm{H}), 5.23-$ 4.63 (m, 1H), $3.54-3.33$ (m, 2H), $3.26-3.16$ (m, 2H), 2.90 (s, 2H), $2.76(\mathrm{~s}, 1 \mathrm{H}), 2.61-2.51$ (m, 3H), $2.24-2.00$ (m, 5H); ${ }^{19}$ F NMR (376 MHz, DMSO-d6) $\delta-112.1,-125.6$.

Overview for Table 3 analogs: Supplementary Scheme $\mathbf{S 6}$ shows the method used for the preparation of compounds with a saturated central core. We determined early in the project that the only active isomer in this series of compounds was the cis isomer with the absolute configuration as drawn in the Scheme 1. Since we knew the desired absolute configuration, we began our syntheses by coupling the necessary indole acid with (1R,3R)-3aminocyclohexan-1-ol to provide the amide, which was oxidized to the corresponding ketone with PCC. Analogs in Table 4 are derived from this intermediate 


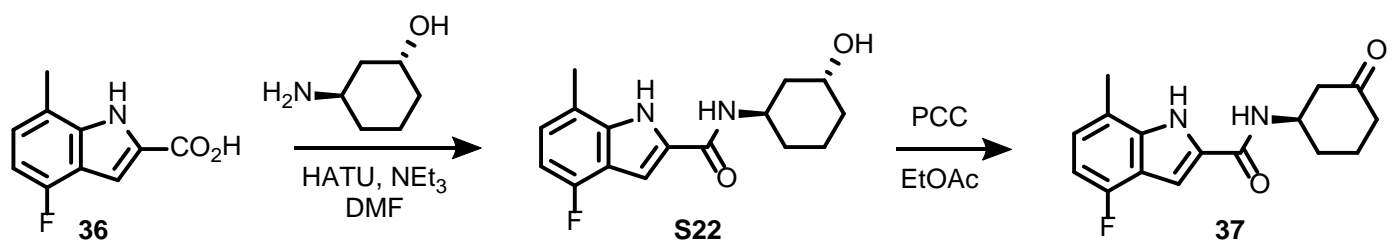

Supplementary Scheme S6: Preparation of analogs in Table 4 through intermediate 37.

Preparation of 37: To a reaction vessel containing 4-fluoro-7-methyl- $1 H$-indole-2-carboxylic acid 36 (4.5 g, 23.3 mmol, 1.0 equiv) was added HATU (10.6 g, 28 mmol, 1.2 equiv), (1R,3R)-3-aminocyclohexan-1-ol (2.7 g, 23.3 mmol, 1.0 equiv) in DMF (50 mL) followed by $N, N^{\prime}$-diisopropylethylamine $\left(9.0 \mathrm{~g}, 69.9 \mathrm{mmol}, 3.0\right.$ equiv) at $21{ }^{\circ} \mathrm{C}$. After stirring for 2 hours, the reaction mixture was diluted with deionized water $(50 \mathrm{~mL})$ and transferred to a separatory funnel containing ethyl acetate $(100 \mathrm{~mL})$. The layers were separated, and the aqueous layer was reextracted with additional ethyl acetate $(2 \times 100 \mathrm{~mL})$. The organic layers were combined and dried over sodium sulfate, filtered, and concentrated under reduced pressure (12 mbar). The residue obtained was purified by flashcolumn chromatography (eluting with 50\% ethyl acetate/petroleum ether to afford 4-fluoro- $N$ - $((1 R, 3 R)-3$ hydroxycyclohexyl)-7-methyl-1H-indole-2-carboxamide (6.5 g, 96\%) as a light yellow solid. LCMS: (ESI, m/z): RT $=0.651 \mathrm{~min}, \mathrm{~m} / \mathrm{z}=291.3[\mathrm{M}+\mathrm{H}]^{+}$(calc $\left.\mathrm{m} / \mathrm{z}=290.1\right) ;{ }^{1} \mathbf{H}$ NMR $(400 \mathrm{MHz}$, methanol- $d 4) \delta 7.21(\mathrm{~s}, 1 \mathrm{H}), 6.99-$ 6.93 (m, 1H), 6.66 (dd, $J=10.4,7.8 \mathrm{~Hz}, 1 \mathrm{H}), 4.42-4.32$ (m, 1H), $4.20-4.135$ (m, 1H), 2.51 (s, 3H), $2.07-1.78$ (m, 3H), $1.79-1.26$ (m, 5H).

Pyridinium chlorochromate (PCC, 5.9 g, 27.6 mmol, 2.0 equiv) was added in a single portion under nitrogen to a round bottom flask equipped with a magnetic stir bar. Ethyl acetate $(50 \mathrm{~mL})$ was added to the vessel followed by 4-fluoro- $N$-((1R,3R)-3-hydroxycyclohexyl)-7-methyl- $1 \mathrm{H}$-indole-2-carboxamide (4.0 g, $13.8 \mathrm{mmol}, 1.0$ equiv). After stirring for 18 hours at $21{ }^{\circ} \mathrm{C}$, the reaction mixture was diluted with aqueous sodium bicarbonate (50 $\mathrm{mL})$ and transferred to a separatory funnel containing ethyl acetate $(100 \mathrm{~mL})$. The layers were separated, and the aqueous layer was re-extracted with additional ethyl acetate $(2 \times 100 \mathrm{~mL})$. The organic layers were combined and dried over sodium sulfate, filtered, and concentrated under reduced pressure (12 mbar). The residue obtained was purified by flash-column chromatography (eluting with $50 \%$ ethyl acetate/petroleum ether to afford 4-fluoro-7methyl-N-((1R)-3-oxocyclohexyl)-1H-indole-2-carboxamide (2.9 g, 73\% yield) as a yellow solid. LCMS: (ESI, $\mathrm{m} / \mathrm{z})$ : RT $=0.729 \mathrm{~min}, \mathrm{~m} / \mathrm{z}=289.25[\mathrm{M}+\mathrm{H}]^{+}($calc $\mathrm{m} / \mathrm{z}=288.13) ;{ }^{1} \mathbf{H}$ NMR $(400 \mathrm{MHz}$, DMSO-d6) $\delta 11.71(\mathrm{~s}, 1 \mathrm{H})$, 8.53 (d, J = 7.7 Hz, 1H), 7.25 (d, $J=2.1 \mathrm{~Hz}, 1 \mathrm{H}), 6.90$ (dd, $J=7.9,5.1 \mathrm{~Hz}, 1 \mathrm{H}$ ), 6.70 (dd, $J=10.4,7.8 \mathrm{~Hz}, 1 \mathrm{H}$ ), $4.25-4.08$ (m, 1H), 2.58 - 2.51 (m, 2H), 2.45 (s, 3H), $2.41-2.15$ (m, 2H), $2.06-1.92$ (m, 2H), 1.82 - 1.56 (m, $2 \mathrm{H})$.

With intermediate 37 in hand, reductive amination with the requisite amine afforded the desired product as a mixture of cis and trans isomers. A cis/trans ratio of 2/1 to 1/1 was typically obtained. The reaction scheme is outlined in Supplementary Scheme S7.

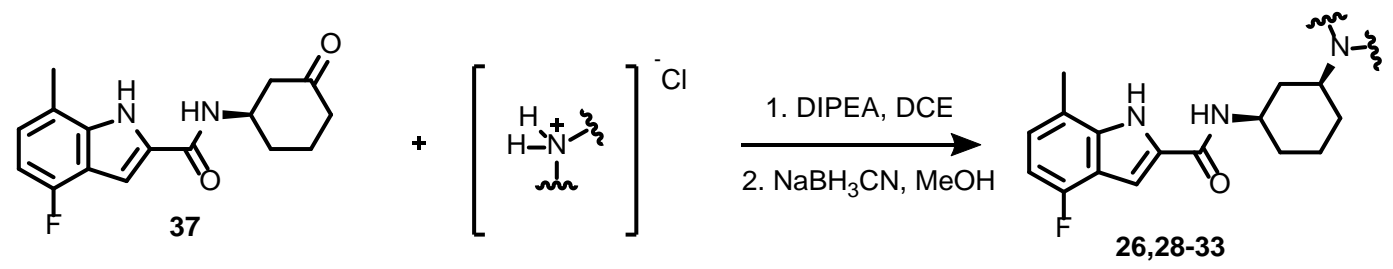

Supplementary Scheme S7: Preparation of analogs 26, 28-33 in Table 4. 
General reaction procedure (GP3): To a reaction vessel containing the amine hydrochloride (0.70 mmol, 2 equiv) suspended in 1,2-DCE (5.0 mL) was added $N$ - $N$ '-diisopropylethylamine $\left(270 \mathrm{mg}, 2.1 \mathrm{mmol}, 6.0\right.$ equiv) at $21^{\circ} \mathrm{C}$. After the reaction had aged 2 hours, the mixture was concentrated under reduced pressure. To this residue, 4-fluoro7-methyl- $N$-((1R)-3-oxocyclohexyl)- $1 H$-indole-2-carboxamide $(100 \mathrm{mg}, 0.35 \mathrm{mmol}, 1.0$ equiv) was added to the flask followed by methanol $(5.0 \mathrm{~mL})$. Sodium cyanoborohydride was added in one portion to the reaction mixture and stirred at $21{ }^{\circ} \mathrm{C}$. After the reaction mixture had aged 18 hours, the product mixture was concentrated under reduced pressure (12 mbar). The residue was purified by Prep-HPLC (conditions listed).

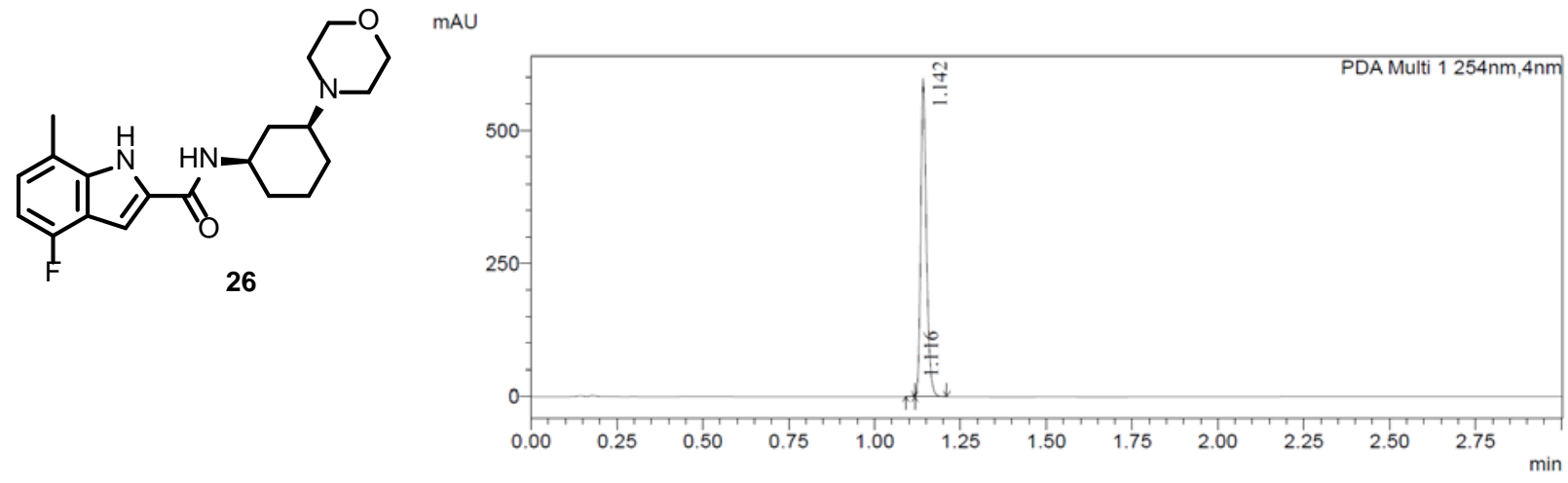

Prepared by using GP3 with 4-fluoro-7-methyl- $N$-((1R)-3-oxocyclohexyl)-1H-indole-2-carboxamide 37 (264 mg, $0.92 \mathrm{mmol}, 1.0$ equiv) and morpholine (160 mg, $1.84 \mathrm{mmol}, 2.0$ equiv) resulting in 4-fluoro-7-methyl- $N$-((1R,3S)-3morpholinocyclohexyl)- $1 H$-indole-2-carboxamide 26 (51 mg, 13\% yield) as a white solid. Prep-HPLC conditions: XBridge Shield RP18 OBD Column, 30*150 mm, $5 \mu \mathrm{m}$; Mobile Phase A: Water(10MMOL/L NH4HCO3), Mobile Phase B: ACN; Flow rate: $60 \mathrm{~mL} / \mathrm{min}$; Gradient: 31\% B to 55\% B in 7 min, 55\% B; Wave Length: 254/220 nm; $\mathrm{RT}=6.67 \mathrm{~min}$; Spectral data: LCMS: Method 2 (ESI, $\mathrm{m} / \mathrm{z}$ ): RT=1.14 min, $\mathrm{m} / \mathrm{z}=360.12[\mathrm{M}+\mathrm{H}]^{+}$(calc $\mathrm{m} / \mathrm{z}=$ 359.20); ${ }^{1}$ H NMR (400 MHz, methanol-d4) $\delta 7.22(\mathrm{~s}, 1 \mathrm{H}), 6.98(\mathrm{dd}, J=7.2,5.1 \mathrm{~Hz}, 1 \mathrm{H}), 6.68$ (dd, $J=10.3,7.9 \mathrm{~Hz}$, 1H), 4.11-4.00 (m, 3H), 3.79 (m, 2H), $3.50(\mathrm{~m}, 2 \mathrm{H}), 3.41(\mathrm{~m}, 2 \mathrm{H}), 3.30(\mathrm{~m}, 2 \mathrm{H}), 2.51(\mathrm{~m}, 4 \mathrm{H}), 2.22(\mathrm{~d}, J=10.8 \mathrm{~Hz}$, 1H), 2.10-2.01 (m, 2H), 1.63-1.40 (m, 4H); ${ }^{19}$ F NMR (282 MHz, methanol-d4) $\delta$-128.0.

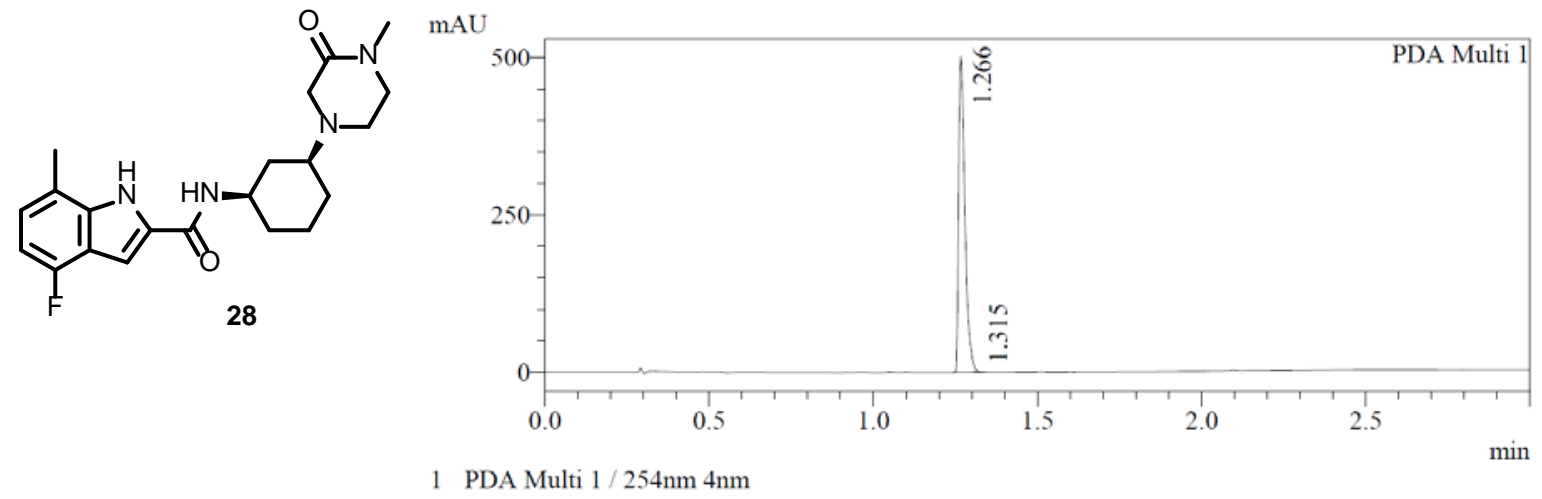

Prepared by using GP3 with 4-fluoro-7-methyl- $N$-((1R)-3-oxocyclohexyl)- $1 H$-indole-2-carboxamide 37 (200 mg, $0.71 \mathrm{mmol}, 1.0$ equiv) and 1-methylpiperazin-2-one (161 mg, $1.41 \mathrm{mmol}, 2.0$ equiv) resulting in 4-fluoro-7-methyl$\mathrm{N}$-((1R,3S)-3-(4-methyl-3-oxopiperazin-1-yl)cyclohexyl)-1H-indole-2-carboxamide $\mathbf{2 8}$ (15 $\mathrm{mg}, \mathbf{1 0 \%}$ yield) as a

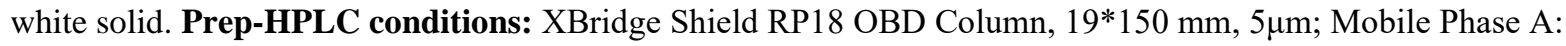
Water(10 mmol/L $\left.\mathrm{NH}_{4} \mathrm{HCO}_{3}\right)$, Mobile Phase B: ACN; Flow rate: $25 \mathrm{~mL} / \mathrm{min}$; Gradient: 26\% B to $42 \%$ B in 10 min, 
42\% B; Wave Length: 254/220 nm; RT=9.27 min; Spectral data: LCMS: Method 2 (ESI, $\mathrm{m} / \mathrm{z}$ ): RT=1.27 min, $\mathrm{m} / \mathrm{z}$ $=408.85[\mathrm{M}+\mathrm{Na}]^{+}$(calc $\left.\mathrm{m} / \mathrm{z}=409.20\right) ;{ }^{1} \mathbf{H}$ NMR $(400 \mathrm{MHz}$, methanol-d4) $\delta 7.17(\mathrm{~s}, 1 \mathrm{H}), 6.95(\mathrm{dd}, \mathrm{J}=5.2,1.2 \mathrm{~Hz}$, 1H), 6.64 (dd, J = 10.4, 7.6 Hz, 1H), 3.97-3.94 (m, 1H), 3.38 (t, J = 5.5 Hz, 2H), 3.30 (s, 2H), 2.96 (s, 3H), 2.94-2.85 (m, 2H), 2.60-2.56 (m, 1H), 2.51 (s, 3H), 2.22-2.19 (m, 1H), 2.03-1.90 (m, 3H), 1.50-1.25 (m, 4H); ${ }^{19} \mathbf{F}$ NMR (376 MHz, methanol- $d 4) \delta-128.0$.

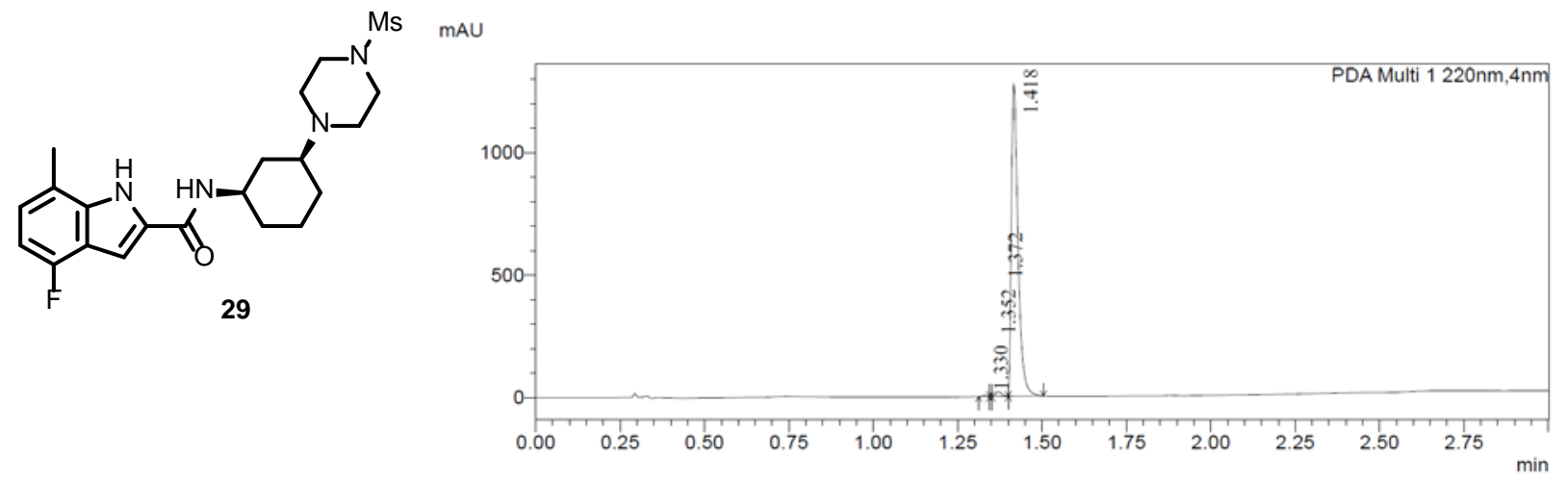

Prepared by using GP3 with 4-fluoro-7-methyl- $N$-((1R)-3-oxocyclohexyl)- $1 H$-indole-2-carboxamide 37 (100 mg, $0.35 \mathrm{mmol}, 1.0$ equiv) and 1-methanesulfonyl piperazine ( $85 \mathrm{mg}, 0.52 \mathrm{mmol}, 1.5$ equiv) resulting in 4-fluoro-7methyl- $N$-((1R,3S)-3-(4-(methylsulfonyl)piperazin-1-yl)cyclohexyl)-1H-indole-2-carboxamide 29 (15 mg, 10\% yield) as a white solid. Prep-HPLC conditions: Shim-pack XR-ODS C18, Column, 50*3.0 mm, $2.2 \mu \mathrm{m}$; Mobile Phase A: water/0.05\%TFA, Mobile Phase B: ACN/0.05\%TFA; Flow rate: $1.2 \mathrm{~mL} / \mathrm{min}$; Wave Length: $220 \mathrm{~nm}$; RT=1.42 min; Spectral data: LCMS: Method 2 (ESI, $\mathrm{m} / \mathrm{z}$ ): RT=1.42 $\mathrm{min}, \mathrm{m} / \mathrm{z}=437.3[\mathrm{M}+\mathrm{H}]^{+}(\mathrm{calc} \mathrm{m} / \mathrm{z}=436.2)$; ${ }^{1}$ H NMR (400 MHz, methanol-d4) $\delta 7.21(\mathrm{~s}, 1 \mathrm{H}), 6.96$ (dd, $\left.J=4.8,0.8 \mathrm{~Hz}, 1 \mathrm{H}\right), 6.66$ (dd, $J=10.4,8.0 \mathrm{~Hz}, 1 \mathrm{H}$ ), 3.99-3.92 (m, 1H), 3.20 (t, $J=4.7 \mathrm{~Hz}, 4 \mathrm{H}), 2.82(\mathrm{~s}, 3 \mathrm{H}), 2.68(\mathrm{~m}, 4 \mathrm{H}), 2.49$ (m, 4H), 2.18 (d, $J=11.6 \mathrm{~Hz}, 1 \mathrm{H}), 1.97$ (d, $J=11.6 \mathrm{~Hz}, 1 \mathrm{H}), 1.92-1.88(\mathrm{~m}, 2 \mathrm{H}), 1.43-1.23(\mathrm{~m}, 4 \mathrm{H}) ;{ }^{19} \mathbf{F}$ NMR (376 MHz, methanol-d4) $\delta$-127.9.

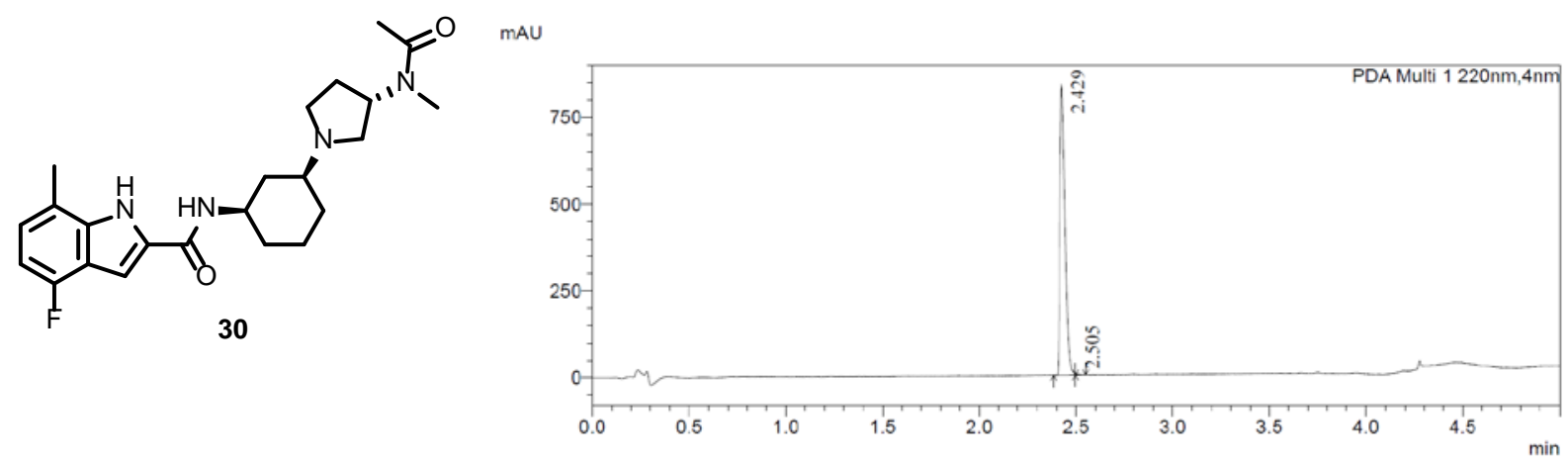

Prepared by using GP3 with 4-fluoro-7-methyl- $N$-((1R)-3-oxocyclohexyl)-1H-indole-2-carboxamide 37 (100 mg, $0.35 \mathrm{mmol}, 1.0$ equiv) and $N$-methyl- $N$-[(3S)-pyrrolidin-3-yl]acetamide (74 mg, $0.52 \mathrm{mmol}, 1.5$ equiv) resulting in 4-fluoro-7-methyl- $N$-((1R,3S)-3-((3S)-3-( $N$-methylacetamido)pyrrolidin-1-yl)cyclohexyl)-1H-indole-2-carboxamide 30 (16 mg, 11\% yield) as an off-white solid. Prep-HPLC conditions: XBridge Shield RP18 OBD Column, 30*150 $\mathrm{mm}, 5 \mu \mathrm{m}$; Mobile Phase A: Water (10 mmol/ $\mathrm{L} \mathrm{NH}_{4} \mathrm{HCO}_{3}$ ), Mobile Phase B: ACN; Flow rate: $60 \mathrm{~mL} / \mathrm{min}$; Gradient: 34\% B to 53\% B in 7 min, 53\% B; Wave Length: 254 nm; RT=5.98 min; Spectral data: LCMS: Method 2 
(ESI, $m / z)$ : RT=2.43 min, $m / z=415.20[\mathrm{M}+\mathrm{H}]^{+}($calc $\mathrm{m} / \mathrm{z}=414.24) ;{ }^{1} \mathbf{H}$ NMR (400 MHz, methanol- $\left.d 4\right) \delta 7.20$ (s, $1 \mathrm{H}), 6.96$ (dd, $J=8.0,6.0 \mathrm{~Hz}, 1 \mathrm{H}), 6.67$ (dd, $J=10.4,8.0 \mathrm{~Hz}, 1 \mathrm{H}), 4.61-4.53(\mathrm{~m}, 1 \mathrm{H}), 4.02-3.96(\mathrm{~m}, 1 \mathrm{H}), 3.01-2.84$ (m, 5H), 2.72-2.64 (m, 2H), 2.51 (s, 3H), 2.30-2.14 (m, 4H), 2.09-1.77 (m, 6H), 1.47-1.26 (m, 4H); ${ }^{19}$ F NMR (282 MHz, methanol-d4) $\delta-128.0$.

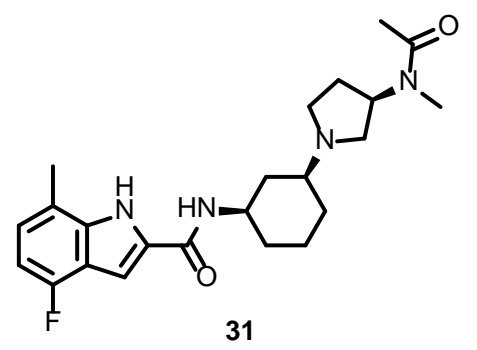

mAU

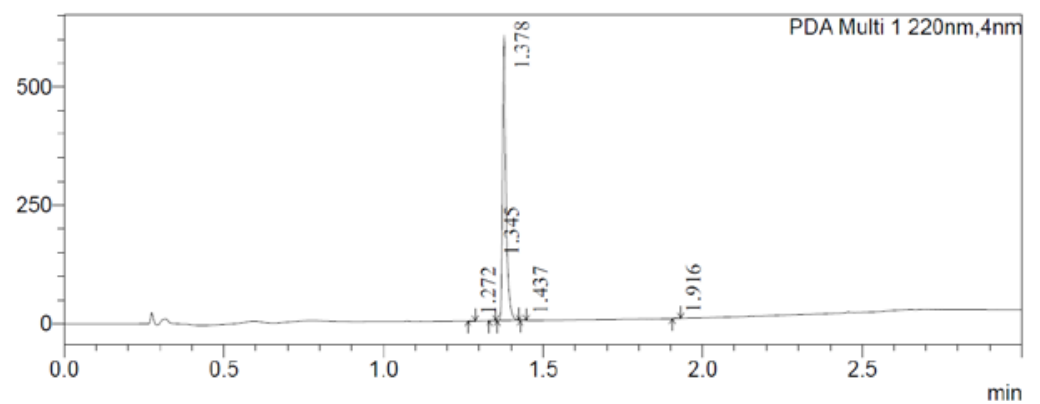

Prepared by using GP3 with 4-fluoro-7-methyl- $N$-((1R)-3-oxocyclohexyl)- $1 H$-indole-2-carboxamide 37 (100 mg, $0.35 \mathrm{mmol}, 1.0$ equiv) and $N$-methyl- $N$-[(3R)-pyrrolidin-3-yl]acetamide (74 mg, $0.52 \mathrm{mmol}, 1.5$ equiv) resulting in 4-fluoro-7-methyl- $N$-((1R,3S)-3-((3R)-3-( $N$-methylacetamido)pyrrolidin-1-yl)cyclohexyl)-1 $H$-indole-2-carboxamide 31 (14 mg, 10\% yield) as an off-white solid. Prep-HPLC conditions: XBridge Shield RP18 OBD Column, 30*150 $\mathrm{mm}, 5 \mu \mathrm{m}$; Mobile Phase A: Water $\left(10 \mathrm{mmol} / \mathrm{L} \mathrm{NH}_{4} \mathrm{HCO}_{3}\right)$, Mobile Phase B: ACN; Flow rate: $60 \mathrm{~mL} / \mathrm{min}$; Gradient: 34\% B to 44\% B in $7 \mathrm{~min}, 44 \% \mathrm{~B}$; Wave Length: $220 \mathrm{~nm}$; RT=4.78 min; Spectral data: LCMS: Method 2 (ESI, $\mathrm{m} / \mathrm{z})$ : RT=1.38 min, $\mathrm{m} / \mathrm{z}=415.30[\mathrm{M}+\mathrm{H}]^{+}($calc $\mathrm{m} / \mathrm{z}=414.24) ;{ }^{1} \mathbf{H}$ NMR $(400 \mathrm{MHz}$, methanol-d4) $\delta 7.20(\mathrm{~s}, 1 \mathrm{H})$, 6.96 (dd, $J=8.0,6.0 \mathrm{~Hz}, 1 \mathrm{H}), 6.67$ (dd, $J=10.4,8.0 \mathrm{~Hz}, 1 \mathrm{H}), 4.61-4.53(\mathrm{~m}, 1 \mathrm{H}), 4.02-3.96(\mathrm{~m}, 1 \mathrm{H}), 3.01-2.84$ (m, 5H), 2.72-2.64 (m, 2H), 2.51 (s, 3H), 2.30-2.14 (m, 4H), 2.09-1.77 (m, 6H), 1.47-1.26 (m, 4H); ${ }^{19}$ F NMR (282 $\mathrm{MHz}$, methanol-d4) $\delta-127.7$.

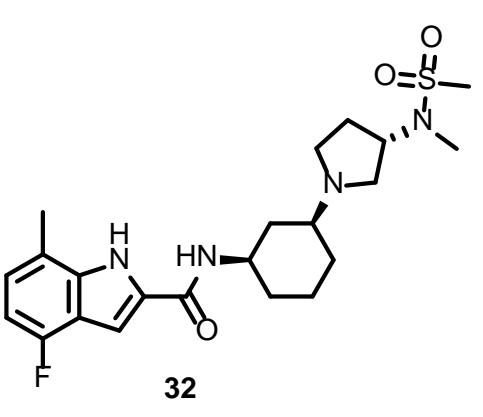

$\mathrm{mAU}$

Prepared by using GP3 with 4-fluoro-7-methyl- $N$-((1R)-3-oxocyclohexyl)-1H-indole-2-carboxamide 37 (100 mg, $0.35 \mathrm{mmol}, 1.0$ equiv) and $N$-methyl- $N$-[(3S)-pyrrolidin-3-yl]methanesulfonamide hydrochloride (149 mg, 0.69 mmol, 2.0 equiv) resulting in 4-fluoro-7-methyl- $N-((1 R, 3 S)-3-((3 S)-3-(N$-methylmethanesulfonamido)pyrrolidin-1yl)cyclohexyl)- $1 \mathrm{H}$-indole-2-carboxamide 32 (32.4 mg, 21\% yield) as an off-white solid. Prep-HPLC conditions:

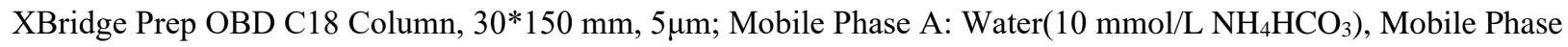
B: ACN; Flow rate: $60 \mathrm{~mL} / \mathrm{min}$; Gradient: 35\% B to $65 \%$ B in $7 \mathrm{~min}, 65 \%$ B; Wave Length: $254 \mathrm{~nm}$; RT=6.12 min; Spectral data: LCMS: Method 2 (ESI, $\mathrm{m} / \mathrm{z})$ : RT=1.40 min, $\mathrm{m} / \mathrm{z}=451.25[\mathrm{M}+\mathrm{H}]^{+}(\mathrm{calc} \mathrm{m} / \mathrm{z}=450.21) ;{ }^{1} \mathbf{H}$ NMR $(300$ MHz, methanol-d4) $\delta 7.22(\mathrm{~s}, 1 \mathrm{H}), 6.95-6.91(\mathrm{~m}, 1 \mathrm{H}), 6.70-6.66(\mathrm{~m}, 1 \mathrm{H}), 4.56-4.30(\mathrm{~m}, 2 \mathrm{H}), 3.14-3.04(\mathrm{~m}$, $1 \mathrm{H}), 2.93-2.81$ (m, 7H), $2.63-2.47$ (m, 4H), $2.44-2.35$ (m, 1H), $2.32-2.06$ (m, 3H), $2.03-1.74$ (m, 4H), 1.71 1.38 (m, 4H); ${ }^{19}$ F NMR (282 MHz, methanol-d4) $\delta 127.98$. 


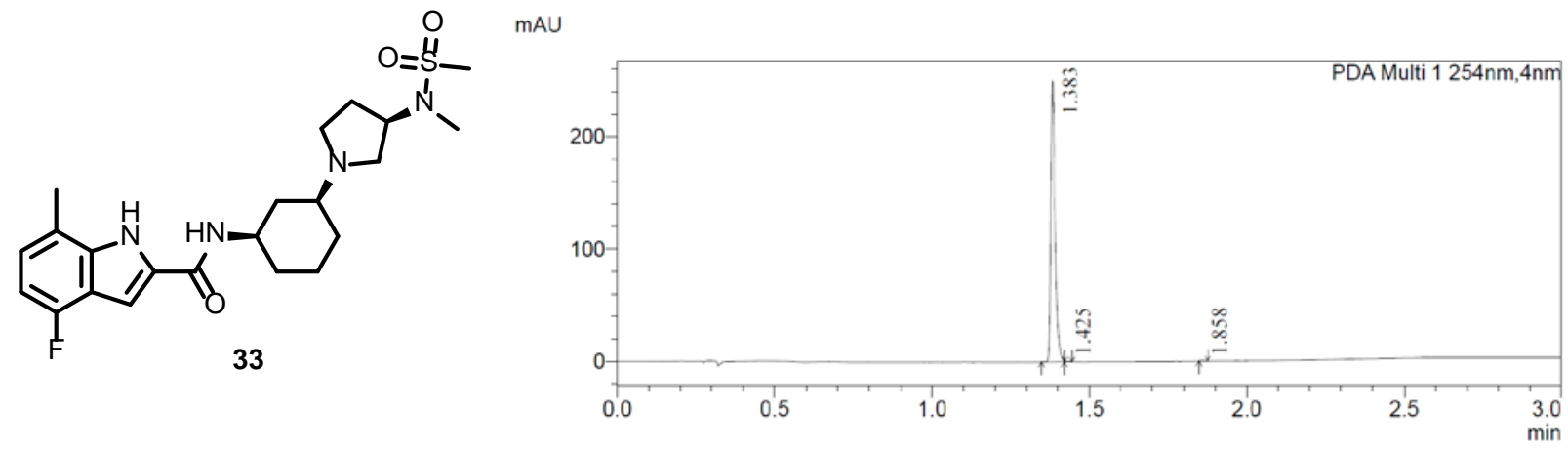

Prepared by using GP3 with 4-fluoro-7-methyl- $N$-((1R)-3-oxocyclohexyl)-1H-indole-2-carboxamide 37 (150 mg, $0.52 \mathrm{mmol}, 1.0$ equiv) and $N$-methyl- $N$-[(3R)-pyrrolidin-3-yl]methanesulfonamide (185 mg, $1.04 \mathrm{mmol}, 2.0$ equiv) resulting in 4-fluoro-7-methyl- $N$-((1R,3S)-3-((3R)-3-( $N$-methylmethanesulfonamido)pyrrolidin-1-yl)cyclohexyl)$1 \mathrm{H}$-indole-2-carboxamide 33 (31 mg, 13\% yield) as an off-white solid. Prep-HPLC conditions: XBridge Prep OBD C18 Column, 30*150 mm, $5 \mu \mathrm{m}$; Mobile Phase A: Water(10 mmol/L $\left.\mathrm{NH}_{4} \mathrm{HCO}_{3}\right)$, Mobile Phase B: ACN; Flow rate: $60 \mathrm{~mL} / \mathrm{min}$; Gradient: 37\% B to 67\% B in $7 \mathrm{~min}, 67 \%$ B; Wave Length: $254 \mathrm{~nm}$; RT: $6.13 \mathrm{~min}$; Spectral data: LCMS: Method 2 (ESI, $\mathrm{m} / \mathrm{z}$ ): RT=1.38 min, $\mathrm{m} / \mathrm{z}=451.25[\mathrm{M}+\mathrm{H}]^{+}$(calc $\left.\mathrm{m} / \mathrm{z}=450.21\right) ;{ }^{1} \mathbf{H}$ NMR $(300 \mathrm{MHz}$, methanol-d4) $\delta(300 \mathrm{MHz}$, methanol-d4) $\delta 7.22(\mathrm{~s}, 1 \mathrm{H}), 6.95-6.91(\mathrm{~m}, 1 \mathrm{H}), 6.70-6.66(\mathrm{~m}, 1 \mathrm{H}), 4.56-4.30(\mathrm{~m}$, 2H), $3.14-3.04$ (m, 1H), $2.93-2.81$ (m, 7H), $2.63-2.47$ (m, 4H), $2.44-2.35$ (m, 1H), $2.32-2.06$ (m, 3H), $2.03-$ $1.74(\mathrm{~m}, 4 \mathrm{H}), 1.71-1.38(\mathrm{~m}, 4 \mathrm{H}) ;{ }^{19} \mathbf{F}$ NMR $(282 \mathrm{MHz}$, methanol- $d 4) \delta 128.0$.

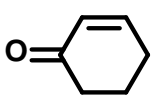

S23

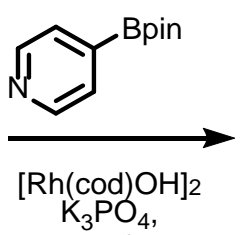

dioxane/water

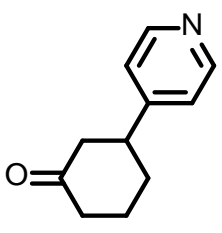

S24

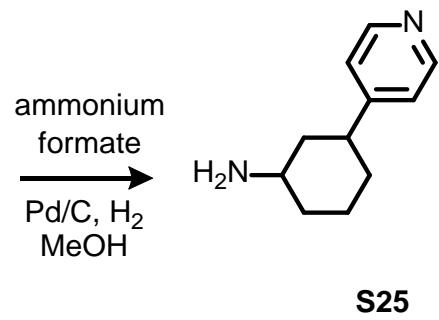

S25

Supplementary Scheme S8: Preparation of reaction intermediates leading to Compound 27.

Preparation of S25: Cyclohexenone S23 (1.0 g, $10.4 \mathrm{mmol}, 1.0$ equiv), potassium carbonate ( $8.83 \mathrm{~g}, 41.6 \mathrm{mmol}, 4.0$ equiv), 4-(4,4,5,5-tetramethyl-1,3,2-dioxaborolan-2-yl)pyridine (4.27 g, $20.8 \mathrm{mmol}, 2.0$ equiv), and [Rh(COD)OH $]_{2}$ (173 mg, $0.26 \mathrm{mmol}, 0.025$ equiv) were added to dioxane/water $(10 \mathrm{~mL} ; 1 / 1)$ under an atmosphere of nitrogen. The reaction mixture was aged for $6 \mathrm{~h}$ with stirring at $60{ }^{\circ} \mathrm{C}$, at which time the reaction was shown to be complete by TLC. The product mixture was then diluted with aqueous sodium chloride solution $(5 \mathrm{~mL})$ and transferred to a separatory funnel containing ethyl acetate $(50 \mathrm{~mL})$ and additional aqueous sodium chloride $(45 \mathrm{~mL})$. The layers were separated, and the aqueous layer was re-extracted with additional ethyl acetate ( 3 x $50 \mathrm{~mL}$ ). The organic layers were combined and dried over sodium sulfate. The dried solution was filtered through a plug of celite and the filtrate was concentrated under reduced pressure (12 mbar). The residue was purified by reverse flash chromatography (C18 silica gel; mobile phase, $\mathrm{MeOH}$ in water, $10 \%$ to $50 \%$ gradient in $10 \mathrm{~min}$; detector, UV $254 \mathrm{~nm}$ ) furnishing 3(pyridin-4-yl)cyclohexan-1-one S24 (1.2 g, 65\% yield) as a light yellow oil. LCMS: Method 4 (ESI, m/z): RT=1.16 $\min , m / z=176.1[\mathrm{M}+\mathrm{H}]^{+}$(calc $\left.m / z=175.1\right)$.

A 2-neck reaction vessel was charged with 3-(pyridin-4-yl)cyclohexan-1-one S24 (1.2 g, 6.85 mmol, 1 equiv), ammonium formate (4.32 g, $68.5 \mathrm{mmol}, 10$ equiv), $\mathrm{Pd} / \mathrm{C}$ (3.6 g), and $\mathrm{MeOH}(20 \mathrm{~mL})$. The solids were stirred for 1 minute and the vessel was evacuated and backfilled with nitrogen (x3). Then a balloon of hydrogen gas was attached to the reaction vessel with an adapter that allowed for the balloon to be closed off to the reaction flask. With the hydrogen balloon closed off, the reaction vessel was evacuated and then the balloon was opened to the 
reaction vessel (x2). After 1 hour, the flask was evacuated and filled with nitrogen, and the solids were filtered through a plug of celite and the filtrate was concentrated under reduced pressure (12 mbar) furnishing 3-(pyridin-4yl)cyclohexan-1-amine S25 (800 mg, 66\%) as a light yellow oil. LCMS: Method 2 (ESI, $\mathrm{m} / \mathrm{z}$ ): RT=0.32 min, $\mathrm{m} / \mathrm{z}$ $=177.2[\mathrm{M}+\mathrm{H}]^{+}($calc $m / z=176.1)$.<smiles>CCCCC1CCCC(c2ccncc2)C1</smiles>

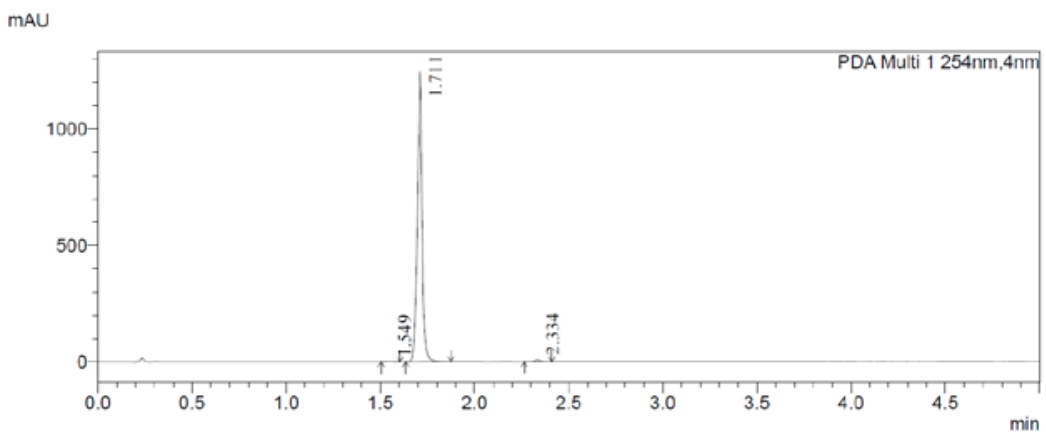

Prepared by using GP2 with 4-flouro-7-methyl-1H-indole-2-carboxylic acid 37 (219 mg, $1.14 \mathrm{mmol}, 1.0$ equiv) and 3-(pyridin-4-yl)cyclohexan-1-amine S25 (200 mg, $1.13 \mathrm{mmol}, 1.0$ equiv) resulting 4-fluoro-7-methyl- $N$-[3-(pyridin4-yl)cyclohexyl]-1 $H$-indole-2-carboxamide (300 mg, 75\% yield) as a light yellow oil. Prep-HPLC conditions: Xselect CSH C18 OBD Column 30*150mm 5 $\mu$ m, n; Mobile Phase A: Water(0.05\%TFA ), Mobile Phase B: ACN; Flow rate: $60 \mathrm{~mL} / \mathrm{min}$; Gradient: 15\% B to 41\% B in 7 min, 41\% B; Wave Length: $220 \mathrm{~nm}$; RT= 6.14 min;

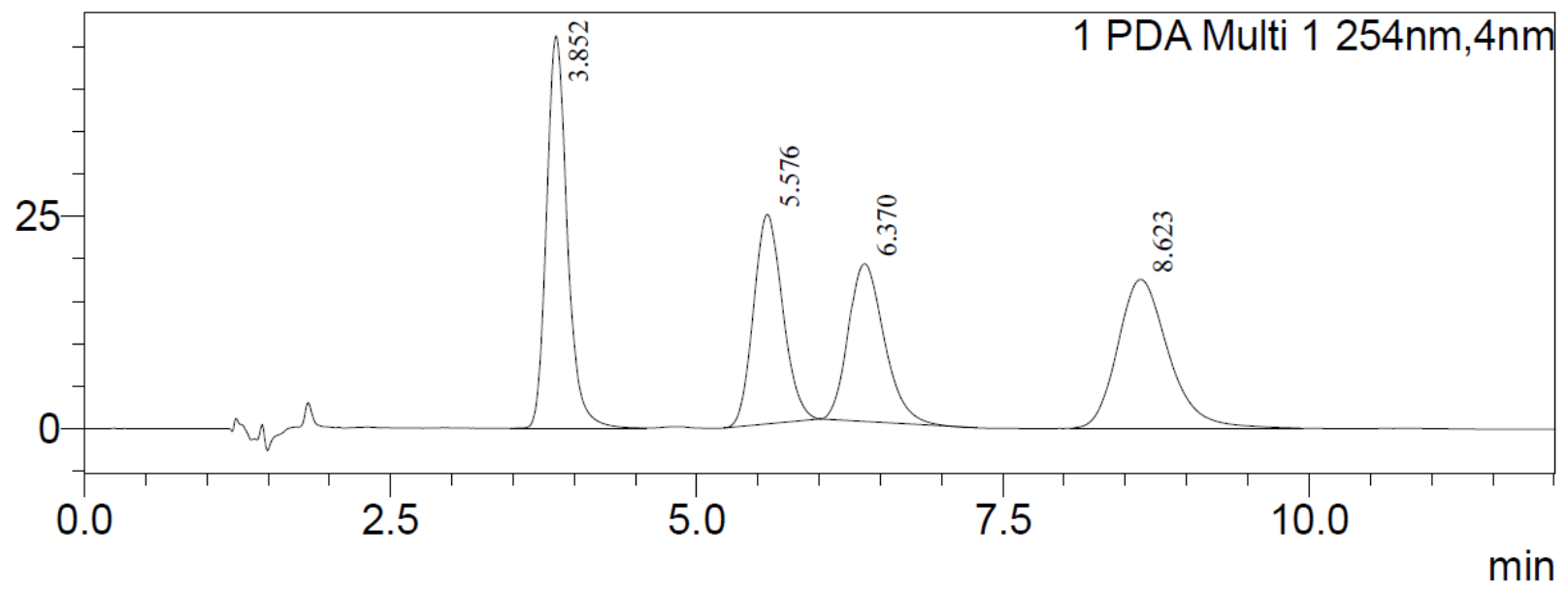

Chiral-prep HPLC conditions: Chiral ADH, 4.6*100mm, 5um; Mobile Phase A: Hex(0.1\%DEA): EtOH=70: 30; Flow rate: $1 \mathrm{~mL} / \mathrm{min}$; Gradient: 0\% B to 0\% B; Injection Volume: 5ul mL; retention time: $6.394 \mathrm{~min}$ 
mAU

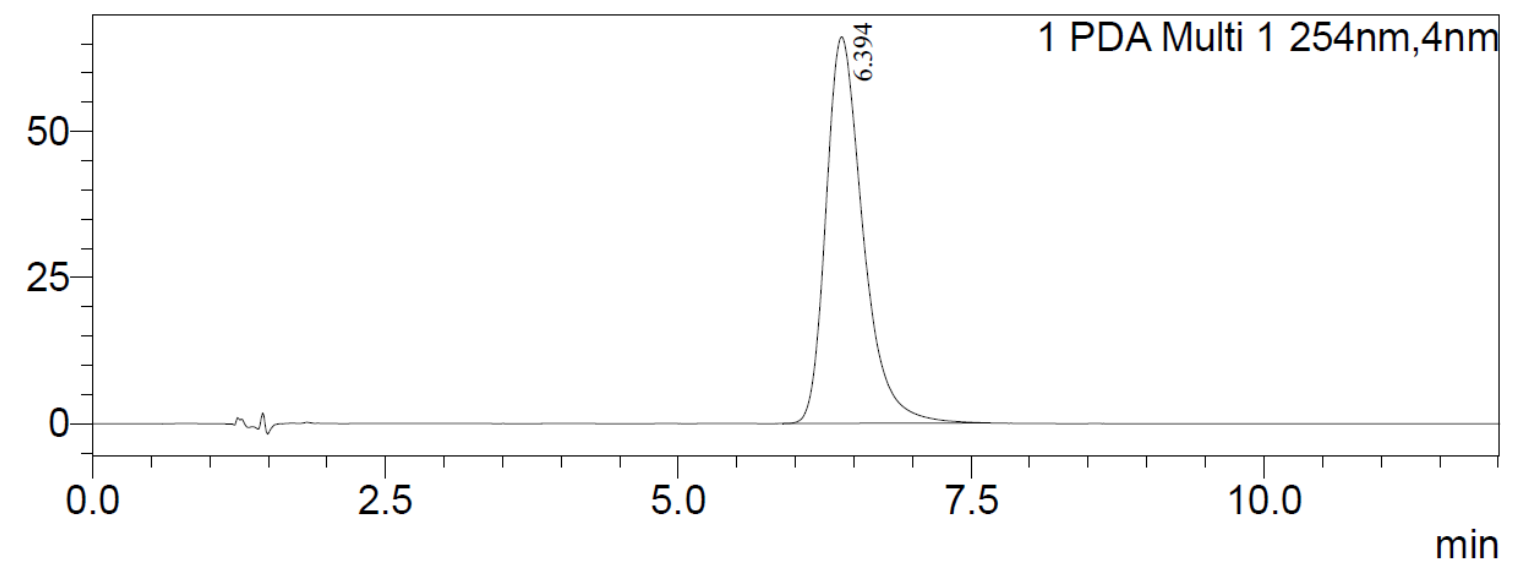

After chiral prep-HPLC, 4-fluoro-7-methyl- $N$-[3-(pyridin-4-yl)cyclohexyl]-1H-indole-2-carboxamide (100 mg) yielded 4-fluoro-7-methyl- $N$-((1R,3S)-3-(pyridin-4-yl)cyclohexyl)-1H-indole-2-carboxamide (15 mg, $15 \%$ yield) as an off-white solid. Spectral data: LCMS: Method 2 (ESI, m/z): RT=1.71 min, m/z =352.2 [M +H] $]^{+}(\mathrm{calc} \mathrm{m} / \mathrm{z}=$ 351.2); ${ }^{1}$ H NMR (400 MHz, methanol-d4) $\delta 8.45-8.44$ (m, 2H), 7.37-7.36 (m, 2H), 7.21 (s, 1H), 6.95 (dd, $J=7.8$, $5.2 \mathrm{~Hz}, 1 \mathrm{H}), 6.66$ (dd, $J=10.3,7.9 \mathrm{~Hz}, 1 \mathrm{H}), 4.14-4.08$ (m, 1H), 2.85-2.79 (m, 1H), 2.50 (s, 3H), 2.22-1.92 (m, 4H), 1.68-1.44 (m, 4H); ${ }^{19}$ F NMR (282 MHz, methanol-d4) $\delta 128.0$.

Stereoisomer Assignment of 4-fluoro-7-methyl- $N-((1 R, 3 S)-3-((3 S)-3-(N-$ methylmethanesulfonamido)pyrrolidin-1-yl)cyclohexyl)-1H-indole-2-carboxamide 32:

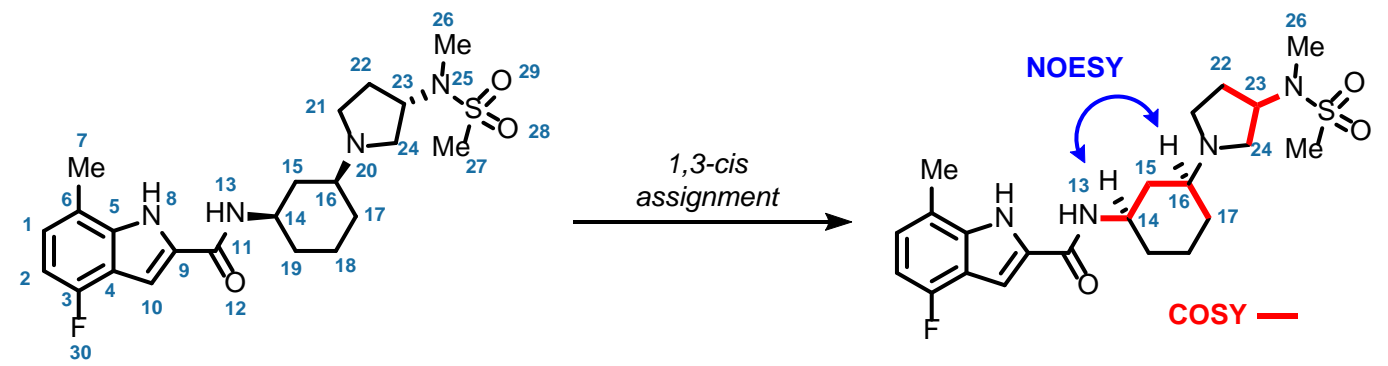

For determination of the depicted stereoisomer of compd 32, 2D NMR (gCOSY, HSQCAD, and 2D NOESY experiments) was used and assignment was made based on the analysis of the data for the two diaxial methines. The 1H NMR spectrum of 32 showed 31 proton signals, including 9 methyl protons, 14 methylene protons, 6 methine protons, and 2 active protons $(\mathrm{N}-\mathrm{H})$.

N-H assignments: The 1H NMR signal at $11.61 \mathrm{ppm}(\mathrm{s}, 1 \mathrm{H})$ showed no correlation in the HSQC spectrum and was assigned to NH-8 according to its chemical shift, COSY correlation (H10), and NOESY correlation (H-7). The 1H NMR signal at $8.31 \mathrm{ppm}(\mathrm{d}, 1 \mathrm{H})$ also showed no correlation in the HSQC spectrum and was assigned to NH-13 according to its chemical shift, COSY correlation (H-14), and NOESY (H-15).

Methyl assignments: The 1H NMR signal at $2.84 \mathrm{ppm}$ (s, 3H) was associated with the 13C NMR signal at $36.8 \mathrm{ppm}$ (HSQC) and is assigned $\mathrm{H}-27$ according to its chemical shift, COSY correlation (H-22/24), and NOESY correlation (H-22/24 and H-23). The $1 \mathrm{H}$ NMR signal at $2.72 \mathrm{ppm}(\mathrm{s}, 3 \mathrm{H})$ was associated with the 13C NMR signal at $29.4 \mathrm{ppm}$ (HSQC) and is assigned to H-26 according to its chemical shift, COSY correlation (H-22/24), and NOESY correlation (H-22/24 and $\mathrm{H}-23)$. The $1 \mathrm{H}$ NMR signal at $2.46 \mathrm{ppm}(\mathrm{s}, 3 \mathrm{H})$ was associated with the 13C NMR signal 
at $17.2 \mathrm{ppm}$ (HSQC) and is assigned to H-7 according to its chemical shift, COSY correlation (H-1), and NOESY (H-1).

Aryl methine assignments: The $1 \mathrm{H}$ NMR signal at $7.19 \mathrm{ppm}(\mathrm{s}, 1 \mathrm{H})$ was associated with the 13C NMR signal at $100.0 \mathrm{ppm}$ (HSQC) and is assigned $\mathrm{H}-10$ according to its chemical shift. The $1 \mathrm{H}$ NMR signal at $6.90 \mathrm{ppm}$ (dd, 1H) was associated with the 13C NMR signal at $124.4 \mathrm{ppm}$ (HSQC) and is assigned to H-1 according to its chemical shift, COSY correlation (H-7), and NOESY correlation (H-7). The $1 \mathrm{H}$ NMR signal at $6.70(\mathrm{dd}, 1 \mathrm{H})$ was associated with the 13C NMR signal at $104.6 \mathrm{ppm}$ (d, split by F) and is assigned $\mathrm{H}-2$ according to its chemical shift.

Aliphatic methine assignments: The 1H NMR signal at $4.31 \mathrm{ppm}(\mathrm{dt}, 1 \mathrm{H})$ was associated with the 13C NMR signal at $55.4 \mathrm{ppm}$ (HSQC) and is assigned H-23 according to its chemical shift, COSY correlation (H-26, H22/24), and NOESY correlation (H-26, H22/24). The 1H NMR signal at $3.85 \mathrm{ppm}(\mathrm{td}, 1 \mathrm{H})$ was associated with the 13C NMR signal at $47.5 \mathrm{ppm}$ (HSQC) and is assigned H-14 according to its chemical shift, COSY correlation (H-13, H-15), and NOESY correlation (H-15, H-16). The 1H NMR signal at $2.12 \mathrm{ppm}(\mathrm{m}, 2 \mathrm{H})$ was associated with the 13C NMR signal at $61.9 \mathrm{ppm}$ (HSQC) and is assigned H-16 according to its chemical shift, COSY correlation (H-15, H-17), and NOESY (H-14, H-15).

1H NMR (400 MHz), DMSO-d6 (32):

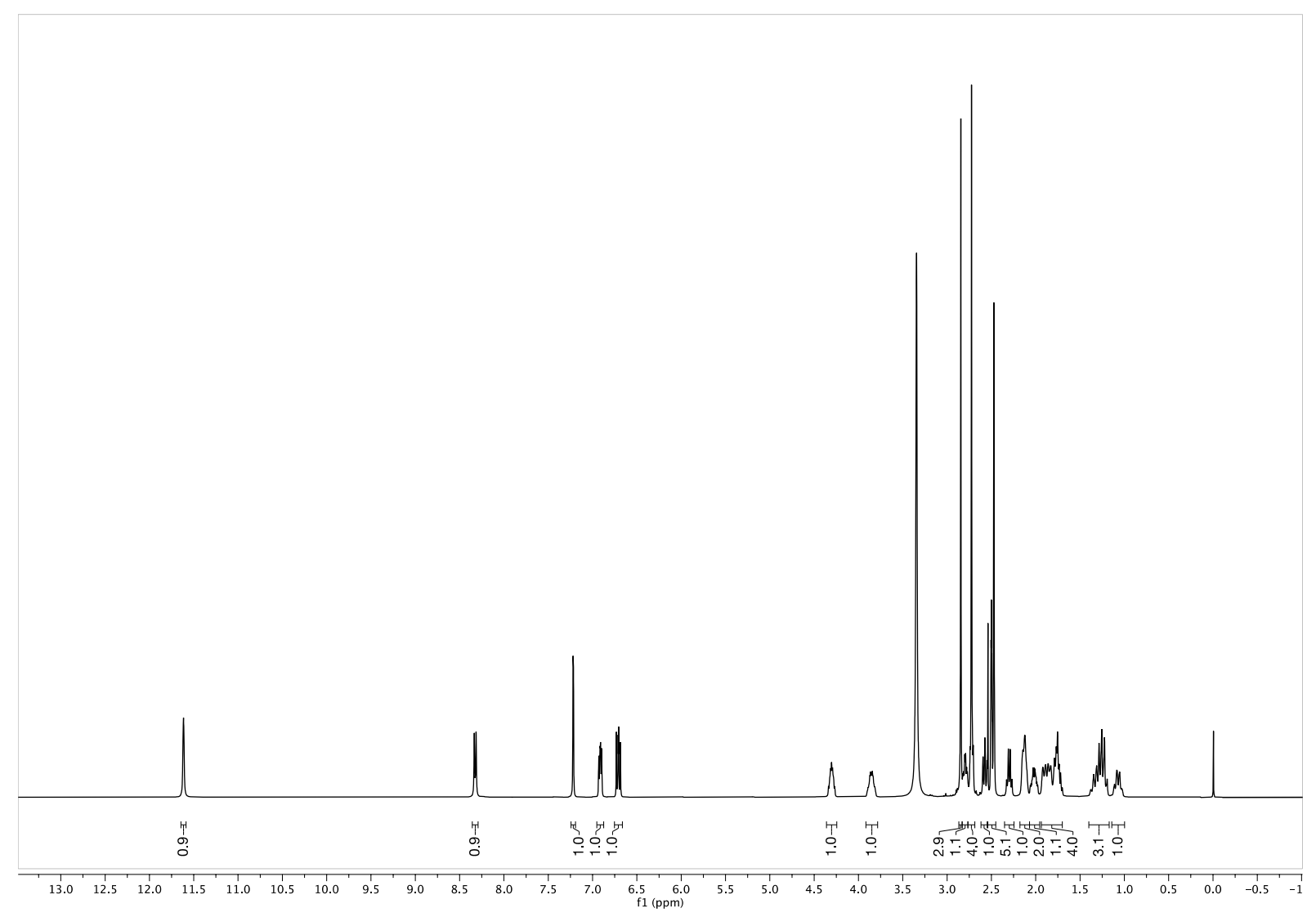


13C NMR (100 MHz)

DMSO-d6 (32):
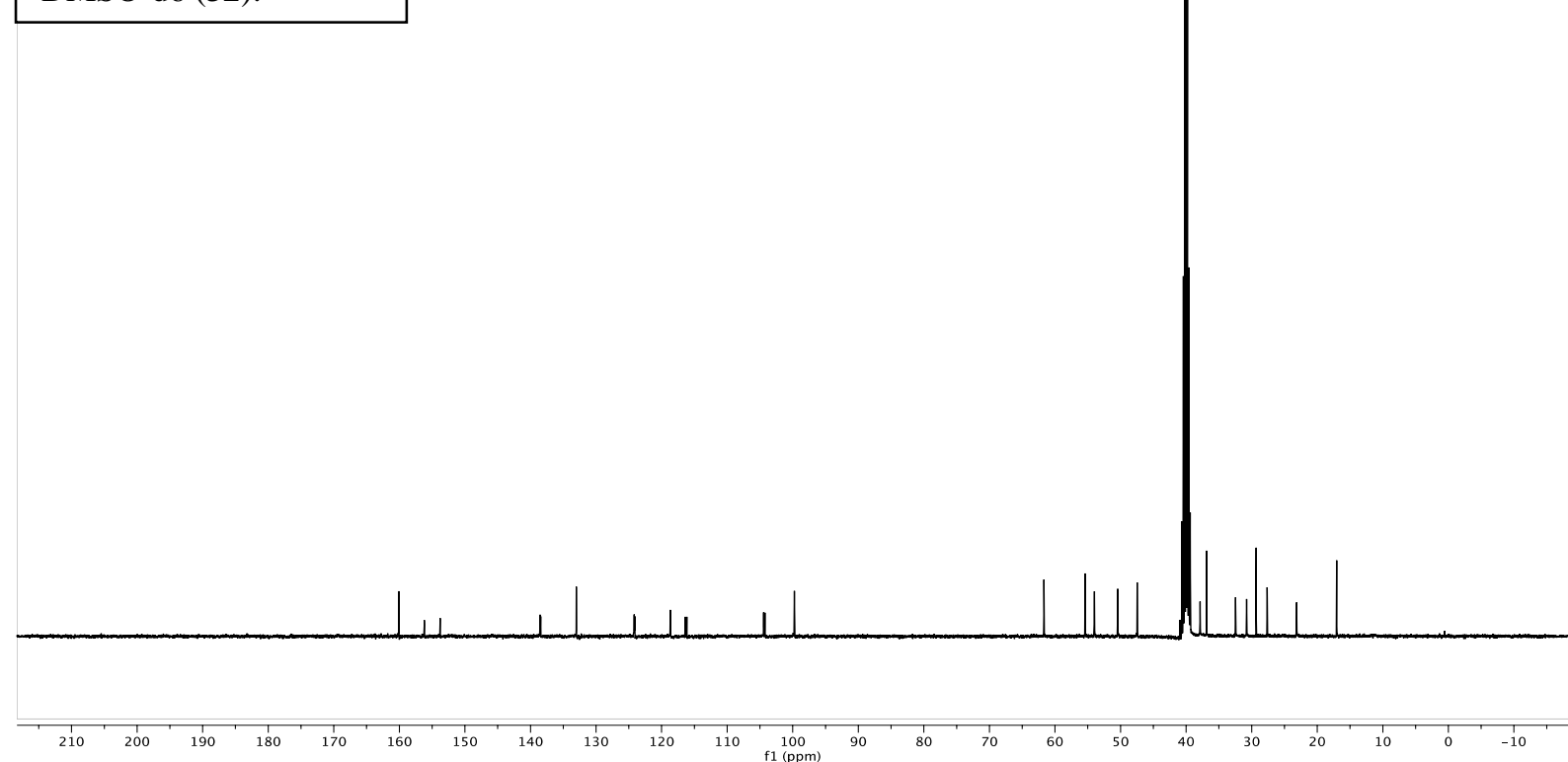

HSQC (400/100 MHz)

DMSO-d6 (32):

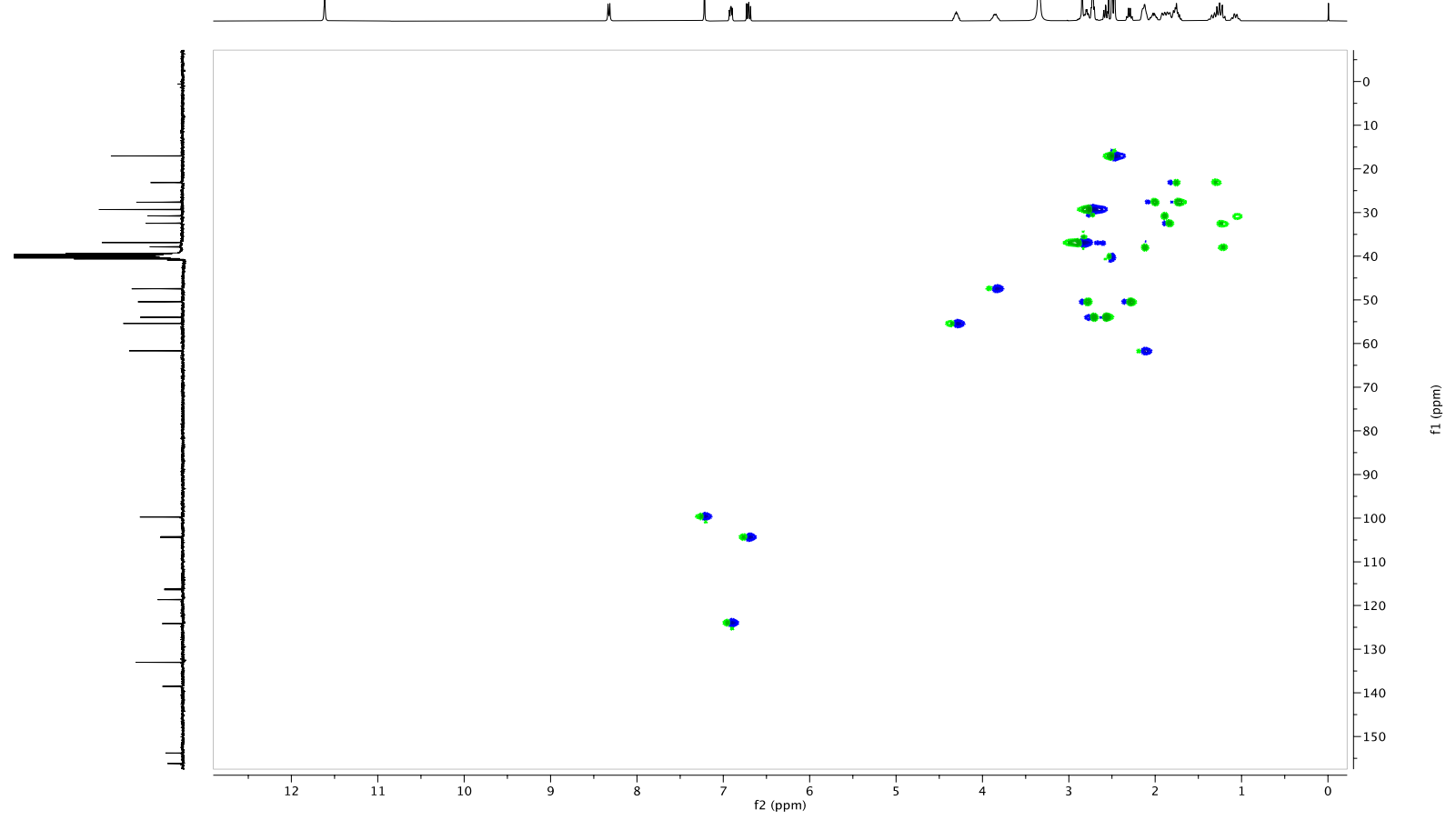



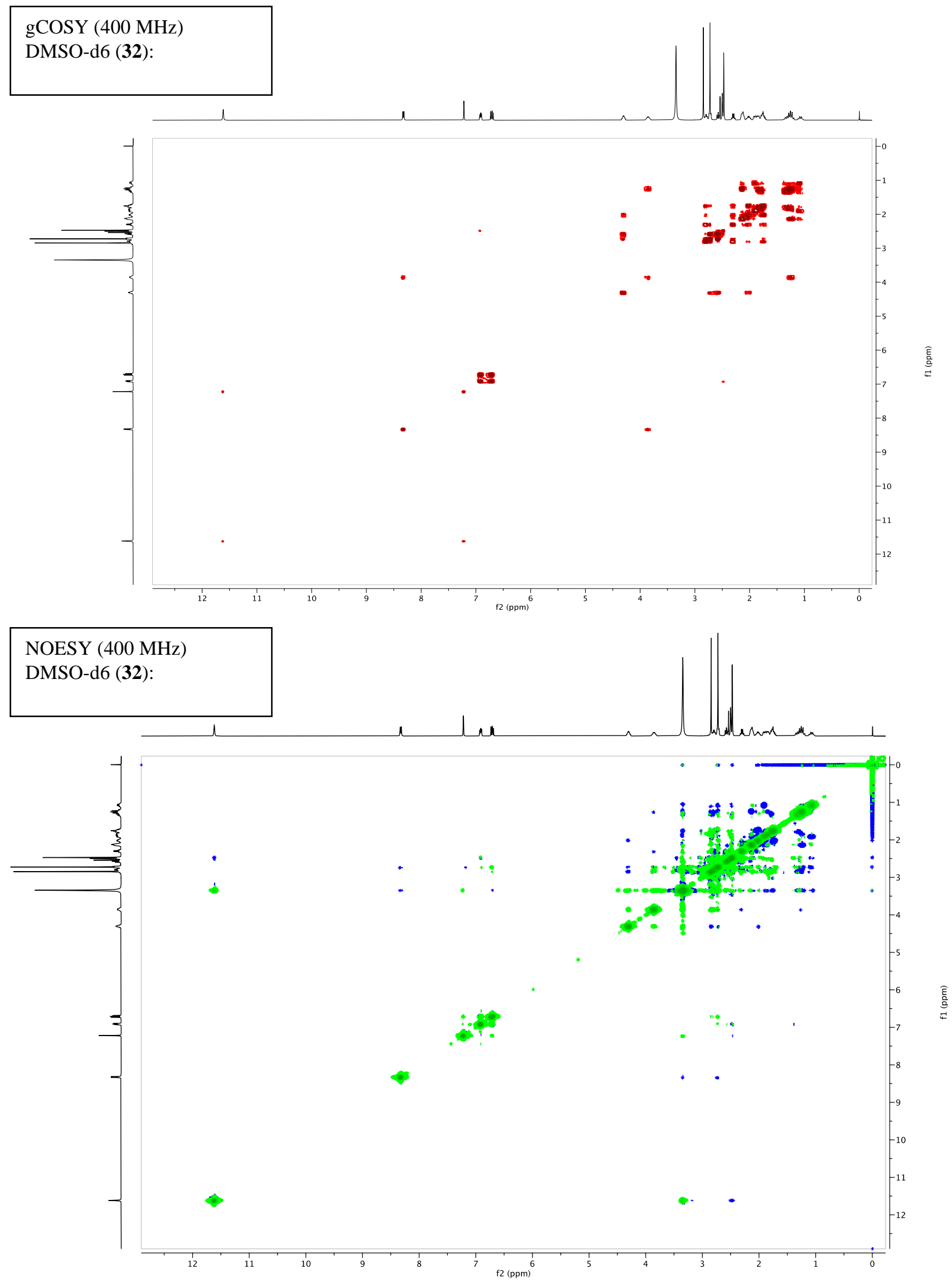

Assay Protocols 
The biochemical assay monitored the incorporation of the tritiated methyl group from S-adenosyl-methionine (SAM) into a biotinylated histone 3 peptide corresponding to residues 26-40. The sequence of the substrate peptide is biotin-Ahx-RKSAPATGGVKKPHR-NH $\mathrm{N}_{2}$ (Biopeptide Co., Inc., San Diego, CA) and ${ }^{3} \mathrm{H}-\mathrm{SAM}$ was purchased from American Radiolabeled Chemicals, Inc. (St. Louis, MO). For the assay, $40 \mu \mathrm{L}$ of enzyme was incubated with $1 \mu \mathrm{L}$ of compound or DMSO for 30 minutes before initiating the reaction with $10 \mu \mathrm{L}$ of substrate solution in a 384well assay plate. The assay was performed at room temperature in assay buffer composed of $25 \mathrm{mM}$ bicine, $\mathrm{pH}$ 8.0, $7.5 \mathrm{mM} \beta$-mercaptoethanol, $0.002 \%$ Tween-20, and $0.01 \%$ bovine skin gelatin (BSG). The reaction was quenched during the linear portion of product formation with $10 \mu \mathrm{L}$ of $1 \mathrm{mM}$ S-adenosyl-homocysteine (SAH) and $1 \mathrm{mM}$ SAM. From the quenched reaction, $50 \mu \mathrm{L}$ was transferred to a streptavidin-coated Flashplate (Perkin Elmer) and incubated for at least $2 \mathrm{~h}$ before washing once with $0.1 \%$ Tween-20. Signal from the ${ }^{3} \mathrm{H}$-labeled peptide captured by the streptavidin-coated plates was counted by a Topcount plate reader (Perkin Elmer). Percent inhibition (\%I) and $\mathrm{IC}_{50}$ values were calculated using equations 1 and 2 respectively.

$$
\begin{gathered}
\% I=\left(1-\left(\frac{S-\min }{\text { max-min }}\right)\right) \\
\% I=(100-\text { bottom })\left(\frac{1}{1+\left(\frac{I C_{50}}{I}\right)^{n}}\right)+\text { bottom }
\end{gathered}
$$

Min is the signal from fully inhibited SETD2 from wells with a final concentration of 20 uM SAH and max is the signal from wells with DMSO instead of compound. For $\mathrm{IC}_{50}$ calculation, bottom is the theoretical minimum \%I, I is the concentration of inhibitor, and $\mathrm{n}$ is the Hill slope. Compound $\mathrm{IC}_{50}$ determination was performed by testing 10 concentrations of compound diluted 3-fold in duplicate at final concentrations of $4 \mathrm{nM}$ enzyme and substrate concentrations equal to their $\mathrm{K}_{\mathrm{M}}$ values of $0.7 \mu \mathrm{M}$ peptide and $2 \mu \mathrm{M}$ SAM. Geometric mean IC 50 values from at least 2 replicates are reported for all active compounds.

The mechanism of inhibition with respect to substrate was tested by measuring the dependence of compound $\mathrm{IC}_{50}$ on substrate concentration. When the concentration of SAM was varied (10, 5, 2.5, 1.25, 0625, and $0.3125 \mu \mathrm{M})$, peptide concentration was fixed at $0.7 \mu \mathrm{M}$. When the concentration of peptide was varied $(5,2.5,1.25,0625$, 0.3125 , and $0.156 \mu \mathrm{M}$ ), the concentration of SAM was fixed at $2 \mu \mathrm{M}$. The inhibition constant (Ki) was determined by the fit of the data to the Cheng-Prushoff equations for either uncompetitive (eq 3) or noncompetitive (eq 4) inhibition ${ }^{1}$.

$$
\begin{gathered}
\mathrm{IC}_{50}=\mathrm{K}_{\mathrm{i}}\left(1+\frac{\mathrm{K}_{\mathrm{M}}}{\mathrm{s}}\right) \\
\mathrm{IC}_{50}=\mathrm{K}_{\mathrm{i}}
\end{gathered}
$$


A

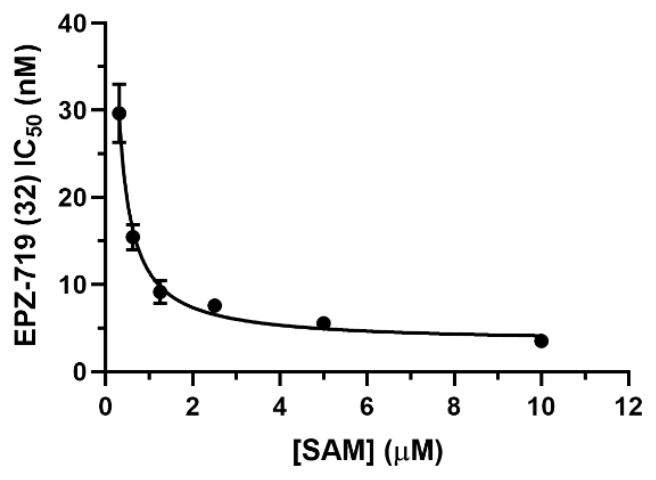

B

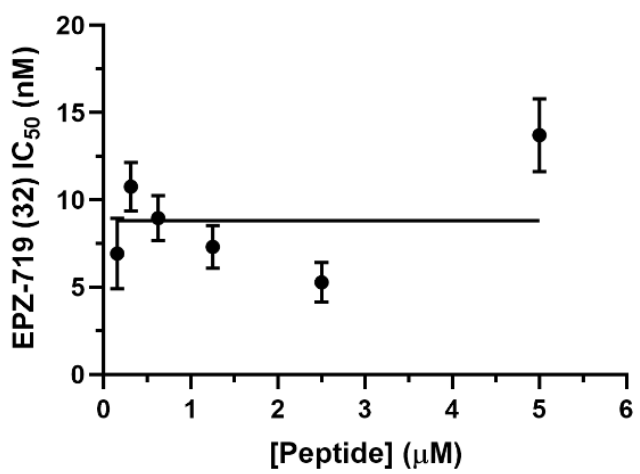

Supplementary Figure S1: Dependence of EPZ-719 (32) IC 50 values on the concentration of (A) SAM and (B) peptide. The solid line shows the fit of the data to eq 3 for uncompetitive inhibition vs SAM (A) and eq 4 for noncompetitive inhibition vs peptide (B).

Inhibition of SETD2 by EPZ-719 (32) is dependent on the concentration of SAM with its potency increasing with increasing SAM concentration (Supplementary Figure S1A). This was best described by uncompetitive inhibition producing a $\mathrm{K}_{\mathrm{i}}$ value of $3.3 \pm 0.1 \mathrm{nM}$. In contrast, inhibition by EPZ-719 (32) is independent of peptide concentration and is best described by noncompetitive inhibition with a $\mathrm{K}_{\mathrm{i}}$ value of $8.8 \pm 1.2 \mathrm{nM}$ (Supplementary Figure S1B). Uncompetitive inhibition vs SAM means that the maximal potency by EPZ-719 (32) requires saturating concentrations of SAM. Since the experiment with varied peptide uses a sub-saturating concentration of SAM, the $\mathrm{K}_{\mathrm{i}}$ value determined will be overestimated. As EPZ-719 (32) inhibition is noncompetitive vs peptide, its potency is best determined from the experiment with varied SAM. Therefore, the more accurate $\mathrm{K}_{\mathrm{i}}$ for EPZ-719 (32) is $3.3 \mathrm{nM}$.

In-cell western (ICW) assay of SETD2 Inhibitors (A549 assay)

1. Reagents and Consumables:

\begin{tabular}{cccc}
$\begin{array}{c}\text { Reagent } \\
\text { Number }\end{array}$ & Reagent Name & $\begin{array}{c}\text { Reagent } \\
\text { Source }\end{array}$ & Catalog Number \\
\hline 1 & A549 & ATCC & CCL-185 \\
2 & F12K & Hyclone & SH30526.01 \\
3 & FBS & Gbico & $10099-141$ \\
4 & Penicillin-Streptomycin & Gbico & $15140-122$ \\
5 & Poly-D-Lysine Black/Clear Microtest (TM) & Corning & 356663 \\
& Tissue-Culture Treated Polystyrene,384-well plate & Concord & \\
7 & Methanol & Technology & \\
7 & PBS powder & Solarbio & P1010
\end{tabular}


8

9

10

12

13

14
Odyssey Blocking Buffer

Tri-Methyl-Histone H3 (Lys36) (D5A7) XP®

Rabbit mAb

Tween-20

IRDye 800CW Goat anti-Rabbit IgG (H + L)(LI-

COR, 926-32211, $0.5 \mathrm{mg}$ )

DRAQ5 (CST, 4084L, 200ul)

384-Well Clear plate
LI-COR

CST

Sigma

LI-COR

CST

Labcyte
$927-40000$

4909S

P2287

926-32211

$4084 \mathrm{~L}$

P-05525

Supplementary Table S1: Reagents for in-cell western assay.

2. Tools and Equipment:

\begin{tabular}{cccc}
$\begin{array}{c}\text { Tool } \\
\text { Number }\end{array}$ & Tool Name & Brand & Model \\
\hline 1 & Cell Counter & Invitrogen & Countess ${ }^{\circledR}$ Automated Cell Counter \\
2 & CO $_{2}$ incubator & Thermo Scientific & 371 \\
3 & Biological Safety Cabinet & Thermo Scientific & 1389 \\
4 & (Class II) & Eppendorf & $5810 \mathrm{R}$ \\
5 & Centrifuge & BioTek & ELx 405 Select CW \\
6 & Echo 550 & Echo & Echo 550 \\
7 & Plate Shaker & Eppendorf & MixMate \\
8 & ODYSSEY CLx & LI-COR & ODYSSEY CLx \\
9 & Multiflo & Biotek & MultiFlo FX \\
10 & Liquid handle system & Tecan & Freedom EVO200
\end{tabular}

Supplementary Table S2: Tools and equipment for in-cell western assay.

\section{Screening Method}

Prepare plates with compounds. Seed A549 cells to the plates with compounds, 4,000 cells/well, $50 \mu \mathrm{L} /$ well. Put the plates at room temperature on a non-vibrating surface for 20 minutes before placing in the incubator. Incubate the plate at $37{ }^{\circ} \mathrm{C}$ incubator with $\mathrm{CO} 2$ for 3 days. Remove plate from incubator and bring to room temperature. Blot media out of the plate and add $50 \mu \mathrm{L}$ of ice cold $100 \%$ methanol. Incubate 30 minutes at room temperature. Remove methanol by aspiration. Wash 3X with PBST. Add $50 \mu \mathrm{L}$ of Blocking Buffer $+0.1 \%$ Tween 20. Incubate 1 hour. Remove Blocking Buffer, wash 3X with PBST. Add $20 \mu \mathrm{L}$ of H3K36me3 (1:1000 dilution). (Cell Signaling Technologies mAb \#4909). Incubate overnight at $4{ }^{\circ} \mathrm{C}$. Wash plate $5 \mathrm{X}$ with PBS-T. Add $20 \mu \mathrm{L}$ of DRAQ5 (1:1000) and IRDye 800CW Goat anti-Rabbit IgG (1:500). Incubate for 1 hour in the dark. Wash plate 5X with PBS-T. Wash plate $3 \mathrm{X}$ with water. Dry by blotting on paper towel, then centrifuge plate upside down on a thin layer of paper towels for 1 minute at $1000 \mathrm{rpm}$ to remove excess reagent. Leave plate uncovered for 10 minutes out of direct light 
before reading. Read on Licor instrument. Geometric mean $\mathrm{IC}_{50}$ values from at least 2 biological replicates are reported for all compounds.

\section{Licor Instrument Settings:}

Preset: Plate; Resolution: $84 \mu \mathrm{m}$; Quality: low; Focus offset: 4.0; 700 channel intensity: 2; and 800 channel intensity: 3.

14 Day KMS-34 Long Term Proliferation (LTP) Assay

1. Reagents, Consumables, and Equipment:

\begin{tabular}{cccc} 
Materials & Source & Cat. No. & Lot. No \\
\hline KMS-34 & JCRB & JCRB1195 & \\
KMS11 & JCRB & JCRB1179 & \\
RPMI 1640 & Invitrogen & $11875-119$ & 1694256 \\
FBS & BI & $04-002-1 A$ & 1609758 \\
96-well plate, flat & Corning & 3599 & \\
Poly-D-Lysine 96-well & BD BIOCOAT & 356640 & \\
Microplates, black/clear & & & \\
Calcein-AM & Invitrogen & C3099 & 1887153 \\
\hline
\end{tabular}

Supplementary Table S3: Reagents for 14-day LTP.

\section{Screening method}

Day 0: In a flat bottom 96-well plate, add $100 \mu \mathrm{L}$ of cells per well at $1.25 \mathrm{X} 10^{5}$ cells/ml density (Note: Only internal wells. PBS placed in all outer wells to avoid evaporation of the internal wells.) Add $50 \mu \mathrm{L}$ of compounds to each well. Final volume in each well is $150 \mu \mathrm{L}$. Incubate plates for $96 \mathrm{hrs}$.

Day 1, 2, 3: wait

Day 4: Pipette cells up and down to mix in each well. Aspirate $20 \mu \mathrm{L}$ of cell suspension in the V-bottom plate and add to a poly-D-lysine coated 96-well plate. Add $30 \mu \mathrm{L}$ HBSS and $50 \mu \mathrm{L}$ of HBSS containing $2 \mu \mathrm{m}$ Calcein-AM. The final concentration is $1 \mu \mathrm{m}$. Let cells sit at RT for 10 mins followed by a quick spin to get cells settled on the bottom of the wells. Incubate the plate for additional 40 mins in the incubator (to load Calcein AM and to give cells more time to attach). Take out the plate and read by Acumen. Calculate the cell numbers taken into account the dilution factors. Split the master plate by taking the total viable cell count calculated. Pipette cells up and down to mix in each well. Aspirate 1.1* of calculated cell suspension from each well and add to a V-bottom plate. Spin the plate at $1100 \mathrm{rpm}$ for 5 minutes. Following the spin remove the media, careful not to disturb the cell pellet. Resuspend pellet in $110 \mu \mathrm{L}$ fresh media. Pipette cells up and down to mix in each well. Aspirate $100 \mu \mathrm{L}$ of cell suspension from each well and add to a new 96-well flat bottom plate. Add $50 \mu \mathrm{L}$ of compound solution. Incubate plates for $72 \mathrm{hrs}$. 
Day 7: Pipette cells up and down to mix in each well. Aspirate $20 \mu \mathrm{L}$ of cell suspension in the V-bottom plate and add to a poly-D-lysine coated 96-well plate. Add $30 \mu \mathrm{L}$ HBSS and $50 \mu \mathrm{L}$ of HBSS containing $2 \mu \mathrm{m}$ Calcein-AM. The final concentration is $1 \mu \mathrm{m}$. Let cells sit at RT for 10 mins followed by a quick spin to get cells settled on the bottom of the wells. Incubate the plate for additional 40 mins in the incubator (to load Calcein AM and to give cells more time to attach). Take out the plate and read by Acumen. Calculate the cell numbers taken into account the dilution factors. Split the master plate by taking the total viable cell count calculated. Pipette cells up and down to mix in each well. Aspirate 1.1* of calculated cell suspension from each well and add to a V-bottom plate. Spin the plate at $1100 \mathrm{rpm}$ for 5 minutes. Following the spin remove the media, careful not to disturb the cell pellet. Resuspend pellet in 110uL fresh media. Pipette cells up and down to mix in each well. Aspirate $100 \mu \mathrm{L}$ of cell suspension from each well and add to a new 96-well flat bottom plate. Add $50 \mu \mathrm{L}$ of compound solution. Incubate plates for $96 \mathrm{hrs}$.

Day 11: Pipette cells up and down to mix in each well. Aspirate $20 \mu \mathrm{L}$ of cell suspension in the V-bottom plate and add to a poly-D-lysine coated 96-well plate. Add $30 \mu \mathrm{L}$ HBSS and $50 \mu \mathrm{L}$ of HBSS containing $2 \mu \mathrm{m}$ Calcein-AM. The final concentration is $1 \mu \mathrm{m}$. Let cells sit at RT for 10 mins followed by a quick spin to get cells settled on the bottom of the wells. Incubate the plate for additional 40 mins in the incubator (to load Calcein AM and to give cells more time to attach). Take out the plate and read by Acumen. Calculate the cell numbers taken into account the dilution factors. Split the master plate by taking the total viable cell count calculated. To reduce the variation that may be caused by pipetting: Pipette cells up and down to mix in each well. Aspirate all the cell suspension from B12, C1-2, D1-2 and add to a V-bottom plate. Aspirate 1.1* of calculated cell suspension from the other wells and add to a V-bottom plate. Spin the plate at $1100 \mathrm{rpm}$ for 5 minutes. Following the spin remove the media, careful not to disturb the cell pellet. Resuspend pellet in B1-2, C1-2, D1-2 in 100uL fresh media. Pipette cells up and down to mix in each well. Resuspend pellet in the other wells in $110 \mu \mathrm{L}$ fresh media. Pipette cells up and down to mix in each well. Aspirate $100 \mu \mathrm{L}$ of cell suspension from each well and add to a new 96-well flat bottom plate.

Day 14: Pipette cells up and down to mix in each well. Aspirate $20 \mu \mathrm{L}$ of cell suspension in the V-bottom plate and add to a poly-D-lysine coated 96-well plate. Add $30 \mu \mathrm{L}$ HBSS and $50 \mu \mathrm{L}$ of HBSS containing $2 \mu \mathrm{m}$ Calcein-AM. The final concentration is $1 \mu \mathrm{m}$. Let cells sit at RT for 10 mins followed by a quick spin to get cells settled on the bottom of the wells. Incubate the plate for additional 40 mins in the incubator (to load Calcein AM and to give cells more time to attach. Take out the plate and read by Acumen. Calculate the cell numbers taken into account the dilution factors.

To calculate growth for days 4,7,11, and 14:

1. Calculate the split factor for day 4 to 7 , day 7 to 11 , and day 11-14 The split factor is the viable cells/mL on Day $\mathrm{X}$ (either 4, 7, or 11) divided by the density the cells are being split back to 2 . For growth of cells from day 4 to 7 , multiply the day 7 viable cells/mL density by the split factor from day 4 .

3. For growth of cells from day 7 to 11 , multiply the day 11 viable cells/mL density by the days 4 , and 7 split factors.

4. For growth of cells from Day 11 to 14, multiply the Day 14 viable cells/mL density by the days 4, 7, and 11 split factors. 5. Plot growth on semi-log chart (viable cells/mL on $\mathrm{Y}$ axis, in log, and days on $\mathrm{X}$ axis).

\section{Compound preparation:}

Compounds were dissolved in DMSO at $10 \mathrm{mM}$ and were stored at $-20^{\circ} \mathrm{C}$. Compounds were diluted with DMSO in 3 -fold serial dilution. From $5 \mathrm{mM}$ to $0.25 \mu \mathrm{m}$. Transfer $1.2 \mu \mathrm{L}$ of compounds from compound plate and add to a 96well plate with $200 \mu \mathrm{L}$ of media in each well. Mix well by pipetting up and down. Transfer $50 \mu \mathrm{L}$ of compoundcontaining media to the cell plate.

\section{Off-Target Screening}

\section{Histone Methyl Transferases}


Compound 32 was tested in a panel of 14 histone methyltransferases to assess its biochemical selectivity across this enzyme class. Other than SETD2, compound 32 displayed at best high micromolar inhibitory potency against these enzymes. These assays were performed as described in Knutson et $\mathrm{al}^{2}$.

\begin{tabular}{cc} 
HMT & IC $_{50}, \mu \mathrm{M}$ \\
\hline DOT1L & $>200$ \\
EZH1 & $>200$ \\
EZH2 & 162 \\
PRMT3 & $>200$ \\
PRMT7 & $>200$ \\
PRMT8 & $>200$ \\
SETD7 & $>200$ \\
SETDB1 & $>200$ \\
SMYD2 & $>200$ \\
WHSC1 & $>200$ \\
EHMT1 & 65.4 \\
EHMT2 & 66.8 \\
PRMT6 & 63.6 \\
SMYD3 & $>200$ \\
\hline
\end{tabular}

Supplementary Table S4: Panel of related histone methyl transferases.

\section{Off-Target Receptor Panel}

Compound 32 was tested in the Eurofins Safety 47 panel, a panel of 47 common off-targets of concern. A set of ten enzymes, 4 kinase and 6 non-kinase (listed below), showed no inhibition $>22 \%$ at $10 \mu \mathrm{M}$.

Enzymes tested: AChE, COX1, COX2, INSR, LCK, MAOA, PDE3A, PDE4D2, ROCK1, VEGFR2

Three transporters, DAT, NET, and SERT, showed no blockade $>15 \%$ at $10 \mu \mathrm{M}$. Eight ion channels were tested, both as openers and blockers except where indicated below. None of the channels reached an $\mathrm{IC}_{50}$ or $\mathrm{EC}_{50}$ below the $10 \mu \mathrm{M}$ top screening concentration.

Ion channels tested: hERG (blocker only), CAV1.2 (blocker only), NAV1.5 (blocker only), GABAA, HTR3A, KvLQT1/minK, nAChR(a4/b2), NMDAR (1A/2B)

The largest category in the panel is the receptors. These are primarily GPCRs, with some NHRs included. These were tested both in agonist and antagonist modes. Only the three targets listed in the table reached an $\mathrm{IC}_{50}$ or $\mathrm{EC}_{50}$ below $10 \mu \mathrm{M}$, the remainder failed to meet this threshold 


\begin{tabular}{lll} 
Receptor & $\mathrm{IC}_{50}$ or $\mathrm{EC}_{50}, \mu \mathrm{M}$ & \multicolumn{1}{c}{ Mode } \\
\hline ADRA1A & 4.36 & antagonist \\
CNR2 & 2.02 & agonist \\
DRD2S & 2.13 & antagonist
\end{tabular}

Supplementary Table S5: Relevant off-target receptor hits.

All receptors tested: ADORA2A, ADRA1A, ADRA2A, ADRB1, ADRB2, AR, AVPR1A, CCKAR, CHRM1, CHRM2, CHRM3, CNR1, CNR2, DRD1, DRD2S, EDNRA, GR, HRH1, HRH2, HTR1A, HTR1B, HTR2A, HTR2B, OPRD1, OPRK1, OPRM1

\section{Kinases}

Compound 32 was tested against a panel of 45 kinases, listed below (Eurofins). No kinase was inhibited $>28 \%$ at 10 $\mu \mathrm{M}$ in this panel. Abl(h), Aurora-A(h), CaMKII $\alpha(\mathrm{h}), \mathrm{CDK} 1 / \mathrm{cyclinB}(\mathrm{h}), \mathrm{CDK} 2 / \mathrm{cyclinA}(\mathrm{h}), \mathrm{CHK} 1(\mathrm{~h}), \mathrm{CHK} 2(\mathrm{~h}), \mathrm{c}-$ RAF(h), cSRC(h), EGFR(h), EphA2(h), EphA3(h), EphB4(h), FGFR1(h), FGFR2(h), FGFR3(h), GSK3 (h),

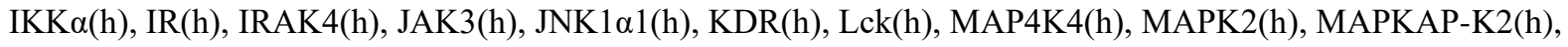

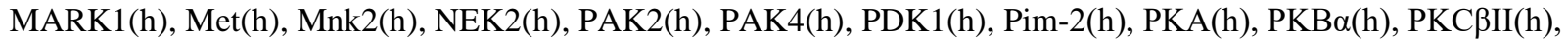
Plk1(h), ROCK-I(h), SAPK2a(h), SGK(h), SIK(h), TAO2(h), TrkA(h) 


\section{In Vitro ADME and Pharmacokinetic Assays}

Stability in Hepatocytes (Pharmaron, Beijing, China)

1. Materials and Reagents

\begin{tabular}{cc} 
Items & Supplier \\
\hline William's E Medium & Life Technologies \\
Human recombinant insulin & Life Technologies \\
GlutaMAX & Life Technologies \\
Isotonic Percoll & General Electric \\
Fetal bovine serum & Corning \\
HEPES & Life Technologies \\
Dexamethasone & Local suppliers (Beijing, China) \\
Mouse Hepatocytes & BioreclamationIVT \\
Human Hepatocytes & BioreclamationIVT \\
\hline
\end{tabular}

Supplementary Table S6: Materials for hepatocyte stability.

2. Study Design

\subsection{Preparation of Working Solutions}

1) Prepare $10 \mathrm{mM}$ stock solutions of test compound(s) and positive control in appropriate solvent (DMSO). Prepare working solutions of test compounds and reference compound in $50 \%$ acetonitrile $/ 50 \%$ water at the concentration of $50 \mu \mathrm{M}$.

\subsection{Preparation of Hepatocytes}

1) Place incubation medium (William's E Medium supplemented with GlutaMAX) and hepatocyte thawing medium in a $37^{\circ} \mathrm{C}$ water bath, and allow warming for at least 15 minutes prior to use. Remove a vial of cryopreserved hepatocytes from storage, ensuring that vials remain at cryogenic temperatures until thawing process ensues. Thaw the cells by placing the vial in a $37^{\circ} \mathrm{C}$ water bath and gently shaking the vials for 2 minutes. After thawing is completed, spray vial with $70 \%$ ethanol, transfer the vial to a biosafety cabinet.

2) Use wide-bore pipette tip to transfer hepatocytes into $50 \mathrm{~mL}$ conical tube containing thawing medium. Place the $50 \mathrm{~mL}$ conical tube into a centrifuge and spin at $100 \times \mathrm{g}$ for 10 minutes. Upon completion of spin, aspirate thawing medium and resuspend hepatocytes in enough incubation medium to yield $\sim 1.5 \times 10^{6}$ cells $/ \mathrm{mL}$.

3) Using AOPI (acridine orange / propidium iodide) staining solution, count cells and determine the viable cell density. Cells with poor viability ( $<75 \%$ viability) are not acceptable for use. Dilute cells with incubation medium to a working cell density of $0.5 \times 10^{6}$ viable cells $/ \mathrm{mL}$.

\subsection{Procedure for Stability Determination}

1) Pipette $198 \mu \mathrm{L}$ of hepatocytes into each wells of a 96-well non-coated plate. Place the plate in the incubator on an orbital shaker to allow the hepatocytes to warm for 10 minutes. Pipette $2 \mu \mathrm{L}$ of working solution to mix with $198 \mu \mathrm{L}$ 
of mouse or human hepatocytes to achieve final concentration of $0.5 \mu \mathrm{M}$. Return the plate to the incubator and place on an orbital shaker.

2) Remove well contents in $25 \mu \mathrm{L}$ aliquots at time points of 0 and 120 minutes for human hepatocytes and 0 and 60 minutes for mouse hepatocytes. The aliquots are then mixed with 6 volumes $(150 \mu \mathrm{L})$ of cold acetonitrile with IS (100 nM alprazolam, $200 \mathrm{nM}$ labetalol, $200 \mathrm{nM}$ caffeine and $2 \mu \mathrm{M}$ ketoprofen) to terminate the reaction. Centrifuge for 30 minutes at $3,220 \times \mathrm{g}$. Aliquots of $100 \mu \mathrm{L}$ of the supernatants will be used for LC/MS/MS analysis. The supernatant may be diluted with ultrapure water according to the LC-MS/MS signal response and peak shape. All incubations will be performed in duplicate.

\subsection{Data analysis}

All calculations were carried out using Microsoft Excel. Peak areas were determined from extracted ion chromatograms. Determine the in vitro half-life $\left(\mathrm{t}_{1 / 2}\right)$ of parent compound by regression analysis of the percent parent disappearance vs. time curve.

a. The in vitro $t_{1 / 2}$ was determined from the slope value: $t_{1 / 2}=0.693 / k$

b. Conversion of the in vitro $\mathrm{t}_{1 / 2}$ (in min) into the scale-up intrinsic clearance (Scaled-up $\mathrm{CL}_{\text {int }}$, in $\mathrm{mL} / \mathrm{min} / \mathrm{kg}$ ) was done using the following equation (mean of duplicate determinations):

Scaled-up $\mathrm{CL}_{\text {int }}=\mathrm{kV} / \mathrm{N} \times$ scaling factor, where $\mathrm{V}=$ incubation volume $(0.2 \mathrm{~mL}) ; \mathrm{N}=$ number of hepatocytes per well $\left(0.1 \times 10^{6}\right.$ cells $)$.

Scaling factors for in vivo intrinsic clearance prediction using different species of hepatocytes are listed below:

\begin{tabular}{|l|l|l|l|}
\hline Species & $\begin{array}{l}\text { Liver Weight } \\
\text { (g liver/kg body weight) }\end{array}$ & $\begin{array}{l}\text { Hepatocyte Concentration } \\
\mathbf{( 1 0}^{\mathbf{6}} \text { cells/g liver) }\end{array}$ & Scaling Factor \\
\hline Human & 25.7 & 99 & 2544 \\
\hline Mouse & 87.5 & 135 & 11812 \\
\hline
\end{tabular}

\subsection{LC-MS/MS analysis}

All samples were analyzed using similar methodology, however different instruments were used over course of time to gather all data. The table below lists the instruments that were used to analyze the samples:

\begin{tabular}{|l|l|}
\hline $\begin{array}{l}\text { Instrument } \\
\text { Type }\end{array}$ & Instrument (Manufacturer) \\
\hline $\begin{array}{l}\text { HPLC } \\
\text { Related } \\
\text { Details }\end{array}$ & $\begin{array}{l}\text { Shimazdu (Shimadzu Corporation; Kyoto, Japan) } \\
\text { Column(s): Waters XSelect HSS T3 C18, } 2.5 \mu m(2.1 \times 30 \mathrm{~mm})-\text { or - } \\
\text { Phenomenex Kinetex } 2.6 \mu \mathrm{m} \text { C18 } 100 \mathrm{R}(2.1 \times 50 \mathrm{~mm}) \\
\text { Column Temperature: } 40^{\circ} \mathrm{C}\end{array}$ \\
\hline $\begin{array}{l}\text { MS/MS } \\
\text { Related }\end{array}$ & $\begin{array}{l}\text { API4000|TripleQuad } 5500 \mid \text { TripleQuad6500+ (Sciex; Framingham, MA, USA) } \\
\text { Ionization source: Electron Spray Ionization (ESI) }\end{array}$ \\
\hline
\end{tabular}


Ionization mode: positive $(+)$

CYP Inhibition in Human Liver Microsomes (Pharmaron, Beijing, China)

\section{Study Procedure}

The master solution was prepared according to table below, and then $1 \mu \mathrm{L}$ of compound solution or $1 \mu \mathrm{L}$ of DMSO was added to the above master solution. The final concentration of control compounds was $10 \mu \mathrm{M}$. The final concentration of test compounds was $50 \mu \mathrm{M}$.

\begin{tabular}{|c|c|c|c|}
\hline Reagent & Stock Concentration & Volume & Final Concentration \\
\hline $\mathrm{MgCl}_{2}$ solution & $50 \mathrm{mM}$ & $20 \mu \mathrm{L}$ & $5 \mathrm{mM}$ \\
\hline Phosphate buffer & $200 \mathrm{mM}$ & $100 \mu \mathrm{L}$ & $100 \mathrm{mM}$ \\
\hline Ultra-pure $\mathrm{H}_{2} \mathrm{O}$ & - & $56 \mu \mathrm{L}$ & - \\
\hline $\begin{array}{c}\text { Human liver } \\
\text { microsomes }\end{array}$ & $20 \mathrm{mg} / \mathrm{mL}$ & $2 \mu \mathrm{L}$ & $0.2 \mathrm{mg} / \mathrm{mL}$ \\
\hline
\end{tabular}

For CYP1A2 inhibition, $1 \mu \mathrm{L}$ of specific drug substrate (Phenacetin: $8 \mathrm{mM}$ ) was added at the final concentration of $40 \mu \mathrm{M}$ to the above solution. For CYP2B6 inhibition, $1 \mu \mathrm{L}$ of specific drug substrate (Bupropion: $10 \mathrm{mM}$ ) was added at the final concentration of $50 \mu \mathrm{M}$ to the above solution. For CYP2C8 inhibition, $1 \mu \mathrm{L}$ of specific drug substrate (Paclitaxel: $1 \mathrm{mM}$ ) was added at the final concentration of $5 \mu \mathrm{M}$ to the above solution. For CYP2C9 inhibition, $1 \mu \mathrm{L}$ of specific drug substrate (Tolbutamide: $40 \mathrm{mM}$ ) was added at the final concentration of $200 \mu \mathrm{M}$ to the above solution. For CYP2C19 inhibition, $1 \mu \mathrm{L}$ of specific drug substrate ((s)-Mephenytoin: $10 \mathrm{mM})$ was added at the final concentration of $50 \mu \mathrm{M}$ to the above solution. For CYP2D6 inhibition, $1 \mu \mathrm{L}$ of specific drug substrate (Dextromethorphan: $2 \mathrm{mM}$ ) was added at the final concentration of $10 \mu \mathrm{M}$ to the above solution. For CYP3A4 inhibition, $1 \mu \mathrm{L}$ of specific drug substrate (Midazolam: $1 \mathrm{mM}$ ) was added at the final concentration of $5 \mu \mathrm{M}$ to the above solution.

The mixture was pre-warmed at $37^{\circ} \mathrm{C}$ for $5 \mathrm{~min}$. The reaction was started by the addition of $20 \mu \mathrm{L}$ of $10 \mathrm{mM}$ NADPH solution at the final concentration of $1 \mathrm{mM}$ and carried out at $37^{\circ} \mathrm{C}$. The reaction was stopped by addition of $400 \mu \mathrm{L}$ of cold quench solution (methanol containing internal standards [IS: $100 \mathrm{nM}$ alprazolam, $500 \mathrm{nM}$ labetalol and $2 \mu \mathrm{M}$ ketoprofen]) at the designated time points (Phenacetin: $20 \mathrm{~min}$; Bupropion: 20 min: Paclitaxel: 10 min; Tolbutamide: 20 min; (s)-Mephenytoin: 20 min; Dextromethorphan: 20 min; Midazolam: 5 min). Samples were vortexed for 5 minutes and centrifuged at $3220 \mathrm{~g}$ for 40 minutes at $4{ }^{\circ} \mathrm{C}$. And then $100 \mu \mathrm{L}$ of the supernatant was transferred to a new 96-well plate with $100 \mu \mathrm{L}$ water (depends on the LC-MS signal response and peak shape) for LC-MS/MS analysis. All experiments were performed in duplicate.

\section{LC-MS/MS analysis}

All samples were analyzed using traditional methodology. For data interpretation, select metabolites of probe substrates noted above were monitored. Selected LC-MS/MS information is noted below:

\begin{tabular}{|l|l|}
\hline $\begin{array}{l}\text { Instrument } \\
\text { Type }\end{array}$ & Instrument (Manufacturer) \\
\hline HPLC & Shimazdu (Shimadzu Corporation; Kyoto, Japan) \\
\hline
\end{tabular}




\begin{tabular}{|c|c|c|c|c|c|c|c|}
\hline $\begin{array}{l}\text { Related } \\
\text { Details }\end{array}$ & \multicolumn{7}{|c|}{$\begin{array}{l}\text { Mobile Phase: } 0.1 \% \text { formic acid in Water }(A) \text { or Acetonitrile (B), elution by gradient } \\
(0.6 \mathrm{~mL} / \mathrm{min}) \\
\text { Column: XSelect Hss T3 } 2.5 \mu(2.1 \times 50 \mathrm{~mm}) \text { Column XPColumn } \\
\text { Temperature: } 40^{\circ} \mathrm{C} \\
1 \text { or } 2 \mu \mathrm{L} \text { injection volume }\end{array}$} \\
\hline $\begin{array}{l}\text { MS/MS } \\
\text { Related } \\
\text { Details }\end{array}$ & \multicolumn{7}{|c|}{$\begin{array}{l}\text { API4000|TripleQuad 5500|TripleQuad6500+ (Sciex; Framingham, MA, USA) } \\
\text { Ionization source: Electron Spray Ionization (ESI) } \\
\text { Ionization mode: positive (+) }\end{array}$} \\
\hline \multicolumn{2}{|c|}{ Marker Metabolite } & Q1 (m/z) & Q3 (m/z) & DP (v) & $\operatorname{EP}(v)$ & CE (v) & $\operatorname{CXP}(v)$ \\
\hline \multicolumn{2}{|c|}{ Acetaminophen } & 152.3 & 110.2 & 80 & 8 & 25 & 10 \\
\hline \multicolumn{2}{|c|}{ OH Bupropion } & 256.1 & 238.2 & 51 & 10 & 10 & 12 \\
\hline \multicolumn{2}{|c|}{ OH Paclitaxel } & 870.3 & 286.2 & 70 & 10 & 20 & 15 \\
\hline \multicolumn{2}{|c|}{ OH Tobutamide } & 287.2 & 188.1 & 51 & 10 & 17 & 12 \\
\hline \multicolumn{2}{|c|}{ OH-mephenytoin } & 235.1 & 150.1 & 50 & 10 & 26 & 12 \\
\hline \multicolumn{2}{|c|}{ Dextrorphan } & 258.1 & 157.1 & 60 & 10 & 35 & 15 \\
\hline \multicolumn{2}{|c|}{ OH-midazolam } & 342.0 & 203.0 & 95 & 10 & 37 & 15 \\
\hline
\end{tabular}

\section{Data Analysis}

Percent inhibition was calculated by comparing peak area of marker metabolite in DMSO control samples to that of test samples. Percent inhibition was then used to estimate an $\mathrm{IC}_{50}$ using the following equation:

$$
\text { Estimated IC50 }=\frac{[\text { Drug }] \times\left(100 \%-\text { Obs }^{\prime} d \operatorname{Inh} \%\right)}{O b s^{\prime} d \operatorname{Inh} \%}
$$

3. Results

\begin{tabular}{|c|c|c|c|c|}
\hline \multirow{2}{*}{ Compound } & $\begin{array}{c}\text { CYP } \\
\text { Isoform }\end{array}$ & [Drug], $\boldsymbol{\mu M}$ & \%Inh & Est. IC $5 \mathbf{5 0}$ \\
\hline \multirow{5}{*}{ Compound 32 } & 1A2 & 50 & 21 & 188 \\
\cline { 2 - 5 } & $2 \mathrm{~B} 6$ & 50 & 28 & 129 \\
\cline { 2 - 5 } & $2 \mathrm{C} 8$ & 50 & 76 & 16 \\
\cline { 2 - 5 } & $2 \mathrm{C} 9$ & 50 & 58 & 36 \\
\cline { 2 - 5 } & $2 \mathrm{C} 19$ & 50 & 42 & 82 \\
\cline { 2 - 5 } & $2 \mathrm{D} 6$ & 50 & 48 & 69 \\
\hline
\end{tabular}

Caco-2 Permeability (Pharmaron, Beijing, China)

1. Material and Reagents

\begin{tabular}{|c|c|}
\hline Items & Supplier \\
\hline DMEM & Corning \\
\hline
\end{tabular}




\begin{tabular}{|c|c|}
\hline FBS & Corning \\
\hline Penicillin, Streptomycin mixture & Solarbio \\
\hline 96-well HTS transwell plate & Corning \\
\hline
\end{tabular}

2. Study Design

\subsection{Preparation of Caco-2 Cells}

$50 \mu \mathrm{L}$ and $25 \mathrm{~mL}$ of cell culture medium were added to each well of the Transwell insert and reservoir, respectively. And then the HTS transwell plates were incubated at $37^{\circ} \mathrm{C}, 5 \% \mathrm{CO}_{2}$ for 1 hour before cell seeding. Caco- 2 cells were diluted to $6.86 \times 10^{5}$ cells $/ \mathrm{mL}$ with culture medium and $50 \mu \mathrm{L}$ of cell suspension were dispensed into the filter well of the 96-well HTS Transwell plate. Cells were cultivated for 14-18 days in a cell culture incubator at $37^{\circ} \mathrm{C}$, $5 \% \mathrm{CO}_{2}, 95 \%$ relative humidity. Cell culture medium was replaced every other day, beginning no later than 24 hours after initial plating.

\subsection{Preparation of Stock Solutions}

$10 \mathrm{mM}$ stock solutions of test compounds were prepared in DMSO. The stock solutions of positive controls were prepared in DMSO at the concentration of $10 \mathrm{mM}$. Digoxin and propranolol were used as control compounds in this assay.

\subsection{Assay Procedures}

The Caco-2 plate was removed from the incubator and washed twice with pre-warmed HBSS (10 mM HEPES, pH 7.4), and then incubated at $37^{\circ} \mathrm{C}$ for 30 minutes. The stock solutions of control compounds were diluted in DMSO to get $1 \mathrm{mM}$ solutions and then diluted with HBSS (10 mM HEPES, $\mathrm{pH} 7.4$ ) to get $5 \mu \mathrm{M}$ working solutions. The stock solutions of the test compounds were diluted in DMSO to get $1 \mathrm{mM}$ solutions, then diluted with HBSS (10 $\mathrm{mM}$ HEPES, $\mathrm{pH}$ 7.4) to get $5 \mu \mathrm{M}$ working solutions. The final concentration of DMSO in the incubation system was $0.5 \%$. To determine the rate of drug transport in the apical to basolateral direction. $75 \mu \mathrm{L}$ of working solution of test compound and control compounds was added to the Transwell insert (apical compartment) and the wells in the receiver plate (basolateral compartment) were filled with $235 \mu \mathrm{L}$ of HBSS (10 mM HEPES, pH 7.4). To determine the rate of drug transport in the basolateral to apical direction, $235 \mu \mathrm{L}$ of working solution of test compound and control compounds was to the receiver plate wells (basolateral compartment) and then the Transwell inserts (apical compartment) were filled with $75 \mu \mathrm{L}$ of HBSS (10 mM HEPES, $\mathrm{pH}$ 7.4). Time 0 samples were prepared by transferring $10 \mu \mathrm{L}$ of working solution to $40 \mu \mathrm{L}$ HBSS (10 mM HEPES, $\mathrm{pH}$ 7.4) in a new 96-well plate, followed by the addition of $200 \mu \mathrm{L}$ cold acetonitrile or methanol containing appropriate internal standards (IS). The plates were incubated at $37^{\circ} \mathrm{C}$ for 2 hours. At the end of the incubation, $10 \mu \mathrm{L}$ samples from donor sides (apical compartment for $\mathrm{A} \rightarrow \mathrm{B}$ flux, and basolateral compartment for $\mathrm{B} \rightarrow \mathrm{A}$ ) to $40 \mu \mathrm{L}$ HBSS (10 mM HEPES, $\mathrm{pH}$ 7.4) and $50 \mu \mathrm{L}$ samples from receiver sides (basolateral compartment for $\mathrm{A} \rightarrow \mathrm{B}$ flux, and apical compartment for $\mathrm{B} \rightarrow \mathrm{A}$ ) were transferred to wells of a new 96-well plate, followed by the addition of 4 volume of cold acetonitrile or methanol containing appropriate internal standards (IS). Samples were vortexed for 5 minutes and then centrifuged at 3,220 $\mathrm{g}$ for 40 minutes. An aliquot of $100 \mu \mathrm{L}$ of the supernatant was mixed with an appropriate volume of ultra-pure water before LC-MS/MS analysis.

\subsection{Data Analysis}

The apparent permeability coefficient (Papp), in units of centimeter per second, can be calculated for Caco-2 drug transport assays using the following equation:

Papp $=($ VA $\times[$ drug $]$ acceptor $) /($ Area $\times$ Time $\times[$ drug]initial, donor $)$

Where VA is the volume (in $\mathrm{mL}$ ) in the acceptor well, Area is the surface area of the membrane $\left(0.143 \mathrm{~cm}^{2}\right.$ for Transwell-96 Well Permeable Supports), and time is the total transport time in seconds. 
The efflux ratio will be determined using the following equation:

Efflux Ratio=Papp(B-A)/Papp(A-B)

Where Papp (B-A) indicates the apparent permeability coefficient in basolateral to apical direction, and Papp (A-B) indicates the apparent permeability coefficient in apical to basolateral direction.

Pharmacokinetics in Mice

\section{Study Design}

A single intravenous (IV) dose was administered to mice (tail vein). Fasted mice were also dosed orally (PO). At the designated time points, blood was collected via the dorsal metatarsal vein in mice. Blood was transferred into collection tubes containing $\mathrm{K}_{2}$-EDTA. For plasma analysis, blood was immediately processed for plasma by centrifugation and stored in a freezer set to be maintained at approximately $-80^{\circ} \mathrm{C}$ until analysis.

\section{Sample Preparation}

The desired serial concentrations of working solutions were achieved by diluting stock solution $(1 \mathrm{mg} / \mathrm{mL}$ in DMSO) of analyte with $50 \%$ acetonitrile in water. Ten microliters of working solutions were added to $10 \mu \mathrm{L}$ of the blank mouse plasma to achieve calibration standards of $0.5-1000 \mathrm{ng} / \mathrm{mL}$ in a total volume of $20 \mu \mathrm{L}$. The resulting 20 $\mu \mathrm{L}$ standard samples were added to $200 \mu \mathrm{L}$ of acetonitrile for protein precipitation. All samples were then vortexed for 30 seconds. After centrifugation at $4^{\circ} \mathrm{C}$ and $4000 \mathrm{rpm}$ (ca. $3740 \mathrm{x} \mathrm{g}$ ) for 15 minutes, the supernatant was diluted with water.

\section{Analytical Method}

Concentrations in extracted samples were determined by liquid chromatography-tandem mass spectrometry (LC-MS/MS) using reversed-phase liquid chromatography. Analytes were monitored using Electron Spray Ionization (ESI) with multiple reaction monitoring in positive ion mode. Peak areas were integrated by Analyst ${ }^{\circledR}$ (Sciex) where concentrations were determined by a weighted $\left(1 / \mathrm{x}^{2}\right)$ linear or quadratic regression of peak area ratios (peak area of analyte/peak area of IS) versus the theoretical concentrations of the plasma calibration standards.

\section{Instruments and Analytical Details}

\begin{tabular}{ll}
\hline \multirow{2}{*}{ HPLC } & $\begin{array}{l}\text { Instrument: Shimadzu (Degasser DGU-20A5; LC-30AD Pumps, CBM-20A Communication } \\
\text { Bus; CTO-30A Column oven; Rack Changer II) }\end{array}$ \\
\hline MS & API 4000 or API5500 \\
\hline Column & Phenomenex Kinetex $5 \mu$ C18 100A (50×2.1 mm) \\
\hline Polarity & Positive ion \\
\hline Mobile Phase & Mobile Phase A: Water $(0.1 \%$ formic acid, $5 \%$ Acetonitrile $)$ \\
\cline { 2 - 2 }$(0.6 \mathrm{~mL} / \mathrm{min})$ & Mobile Phase B: Acetonitrile $(0.1 \%$ formic acid, $5 \%$ Water $)$ \\
\hline
\end{tabular}

\section{Pharmacokinetic Analysis}


Individual plasma concentration-time data of mice were analyzed by non-compartmental methods using the Linear/Log trapezoidal method (IV) or the Linear-up/Log-down trapezoidal method (PO) (Phoenix WinNonlin 6.1, Certara, Princeton, NJ). After IV dosing, clearance (CL), steady-state volume of distribution ( $\mathrm{V}_{\mathrm{ss}}$ ), terminal elimination half-life $\left(t_{1} / 2\right)$, area under the curve from time zero to infinity (AUCINF), mean resonance time from time zero to infinity $\left(\mathrm{MRT}_{\mathrm{INF}}\right)$, and terminal phase volume of distribution $\left(\mathrm{V}_{\mathrm{z}}\right)$ were calculated. After PO dosing, maximum observed concentration $\left(\mathrm{C}_{\max }\right)$, time of $\mathrm{C}_{\max }\left(\mathrm{t}_{\max }\right)$, terminal elimination half-life $\left(\mathrm{t}_{1} / 2\right)$, area under the curve from time zero to infinity $\left(\mathrm{AUC}_{\mathrm{INF}}\right)$, mean resonance time from time zero to infinity $\left(\mathrm{MRT}_{\mathrm{INF}}\right)$, apparent total clearance $(\mathrm{CL} / \mathrm{F})$, bioavailability $(F)$, and estimated fraction absorbed $\left(F_{a}\right)$ were calculated.

5. Results

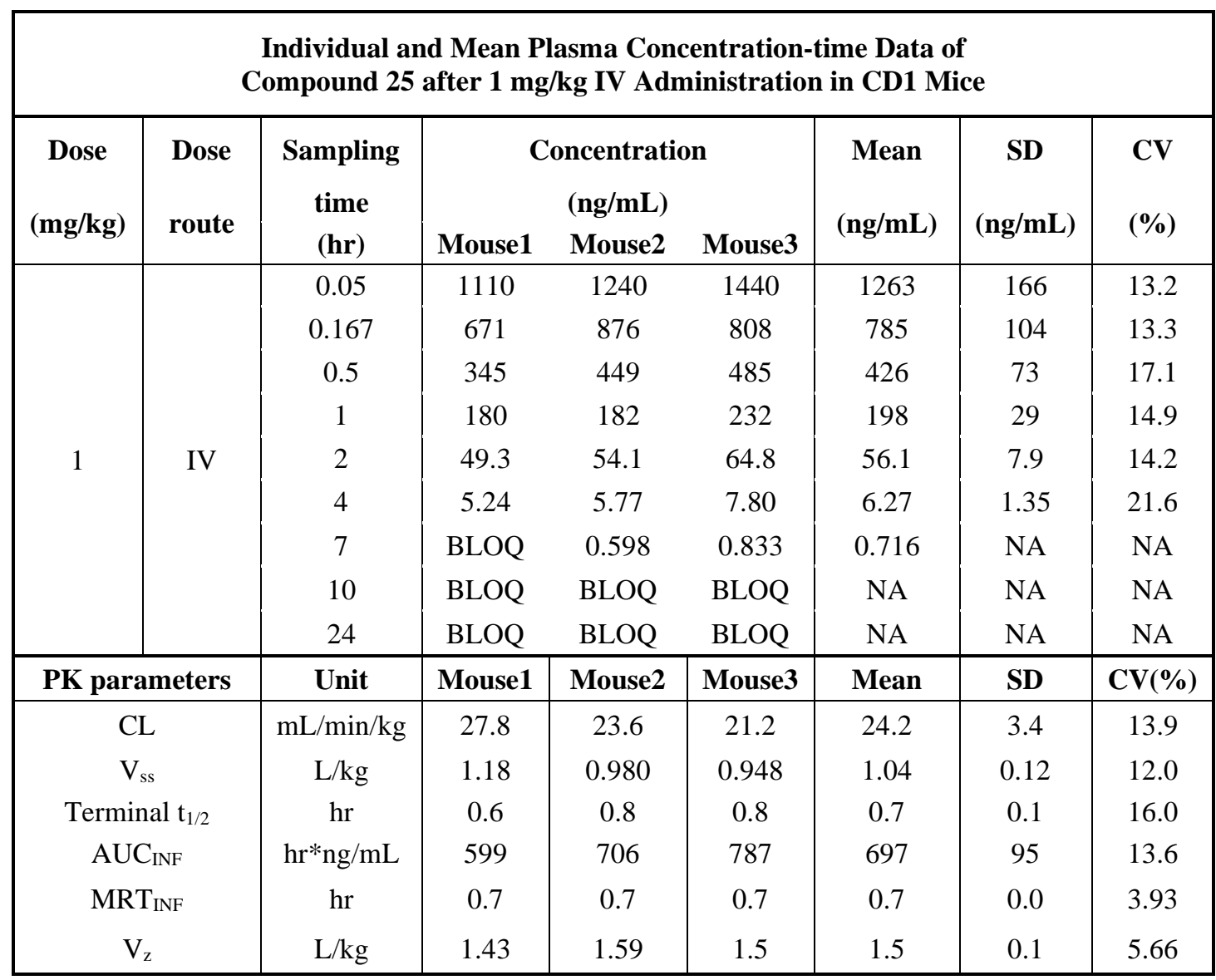

BLOQ $<0.5$ ng/mL

\begin{tabular}{|c|c|c|c|c|c|c|c|c|}
\hline \multicolumn{9}{|c|}{$\begin{array}{l}\text { Individual and Mean Plasma Concentration-time Data of } \\
\text { Compound } 25 \text { after } 50 \mathrm{mg} / \mathrm{kg} \text { PO Administration in CD1 Mice }\end{array}$} \\
\hline \multirow{2}{*}{$\begin{array}{c}\text { Dose } \\
\text { (mg/kg) }\end{array}$} & \multirow{2}{*}{$\begin{array}{l}\text { Dose } \\
\text { route }\end{array}$} & \multirow{2}{*}{$\begin{array}{c}\text { Sampling } \\
\text { Time } \\
\text { (hr) }\end{array}$} & \multicolumn{3}{|c|}{ Concentration } & \multirow{2}{*}{$\begin{array}{c}\text { Mean } \\
\text { (ng/mL) }\end{array}$} & \multirow{2}{*}{$\begin{array}{c}\text { SD } \\
\text { (ng/mL) }\end{array}$} & \multirow{2}{*}{$\begin{array}{l}\text { CV } \\
(\%)\end{array}$} \\
\hline & & & Mouse7 & $\begin{array}{l}\text { (ng/mL) } \\
\text { Mouse8 }\end{array}$ & Mouse9 & & & \\
\hline \multirow{3}{*}{50} & \multirow{3}{*}{ POB } & 0.25 & 18.8 & 22.5 & 7.90 & 16.4 & 7.6 & 46.3 \\
\hline & & 0.5 & 31.7 & 38.7 & 12.3 & 27.6 & 13.7 & 49.6 \\
\hline & & 1 & 35.9 & 51.6 & 25.3 & 37.6 & 13.2 & 35.2 \\
\hline
\end{tabular}




\begin{tabular}{|c|c|c|c|c|c|c|c|} 
& 2 & 33.9 & 31.8 & 30.6 & 32.1 & 1.7 & 5.20 \\
& 4 & 18.8 & 14.2 & 30.2 & 21.1 & 8.2 & 39.1 \\
& 7 & 1.26 & BLOQ & 7.41 & 4.34 & NA & NA \\
& 10 & BLOQ & BLOQ & 0.795 & NA & NA & NA \\
& 24 & BLOQ & BLOQ & BLOQ & NA & NA & NA \\
\hline PK parameters & Unit & Mouse7 & Mouse8 & Mouse9 & Mean & SD & CV(\%) \\
\hline $\mathrm{t}_{\max }$ & $\mathrm{hr}$ & 1.0 & 1.0 & 2.0 & 1.3 & 0.6 & 43.3 \\
$\mathrm{C}_{\max }$ & $\mathrm{ng} / \mathrm{mL}$ & 35.9 & 51.6 & 30.6 & 39.4 & 10.9 & 27.7 \\
Terminal $_{1 / 2}$ & $\mathrm{hr}$ & 1.0 & 1.6 & 1.1 & 1.3 & 0.3 & 25.3 \\
$\mathrm{AUC}_{\text {INF }}$ & $\mathrm{hr}$ ng/mL & 133 & 151 & 161 & 148 & 14 & 9.43 \\
$\mathrm{MRT}_{\text {INF }}$ & $\mathrm{hr}$ & 2.4 & 2.8 & 3.6 & 2.9 & 0.6 & 20.8 \\
$\mathrm{CL}_{\mathrm{F}}$ & $\mathrm{mL} / \mathrm{min} / \mathrm{kg}$ & 6260 & 5520 & 5190 & 5660 & 550 & 9.72 \\
$\mathrm{~F}\left(\mathrm{AUC}_{\mathrm{INF}}\right.$ based) & $\%$ & 0.381 & 0.433 & 0.460 & 0.425 & 0.040 & 9.43 \\
$\mathrm{~F}_{\mathrm{a}}$ & & $<0.01$ & $<0.01$ & $<0.01$ & $<0.01$ & $\mathrm{NA}$ & $\mathrm{NA}$ \\
\hline
\end{tabular}

$\mathrm{BLOQ}<0.5 \mathrm{ng} / \mathrm{mL} ; \mathrm{Fa}=(\% \mathrm{~F} / 100) /\left(1-\left[\mathrm{CL} / \mathrm{Q}_{\mathrm{h}}\right]\right)$, where CL is observed blood clearance and $\mathrm{Q}_{\mathrm{h}}$ is liver blood flow (eg, $90 \mathrm{~mL} / \mathrm{min} / \mathrm{kg}$ for mice).

\begin{tabular}{|c|c|c|c|c|c|c|c|c|}
\hline \multicolumn{9}{|c|}{$\begin{array}{l}\text { Individual and Mean Plasma Concentration-time Data of } \\
\text { Compound } 32 \text { after } 1 \mathrm{mg} / \mathrm{kg} \text { IV Administration in CD1 Mice }\end{array}$} \\
\hline \multirow{3}{*}{$\begin{array}{c}\text { Dose } \\
\text { (mg/kg) }\end{array}$} & \multirow{3}{*}{$\begin{array}{l}\text { Dose } \\
\text { route }\end{array}$} & \multirow{3}{*}{$\begin{array}{c}\text { Sampling } \\
\text { time } \\
\text { (hr) }\end{array}$} & \multirow{2}{*}{\multicolumn{3}{|c|}{$\begin{array}{c}\text { Concentration } \\
(\mathbf{n g} / \mathrm{mL})\end{array}$}} & \multirow{3}{*}{$\begin{array}{c}\text { Mean } \\
\text { (ng/mL) }\end{array}$} & \multirow{3}{*}{$\begin{array}{c}\text { SD } \\
(n g / m L)\end{array}$} & \multirow{3}{*}{$\begin{array}{l}\text { CV } \\
(\%)\end{array}$} \\
\hline & & & & & & & & \\
\hline & & & Mouse1 & Mouse2 & Mouse3 & & & \\
\hline \multirow{9}{*}{1} & \multirow{9}{*}{ IV } & 0.05 & 234 & 293 & 294 & 274 & 34 & 12.6 \\
\hline & & 0.167 & 183 & 220 & 258 & 220 & 38 & 17.0 \\
\hline & & 0.5 & 136 & 131 & 120 & 129 & 8 & 6.35 \\
\hline & & 1 & 71.5 & 65.3 & 61.9 & 66.2 & 4.9 & 7.35 \\
\hline & & 2 & 43.8 & 29.3 & 35.5 & 36.2 & 7.3 & 20.1 \\
\hline & & 4 & 23.9 & 17.4 & 15.1 & 18.8 & 4.6 & 24.3 \\
\hline & & 7 & 8.37 & 5.45 & 6.38 & 6.73 & 1.49 & 22.2 \\
\hline & & 10 & 3.50 & 2.66 & 3.30 & 3.15 & 0.44 & 13.9 \\
\hline & & 24 & 0.519 & BLOQ & BLOQ & NA & NA & NA \\
\hline \multicolumn{2}{|c|}{ PK parameters } & Unit & Mouse1 & Mouse2 & Mouse3 & Mean & SD & $\mathrm{CV}(\%)$ \\
\hline \multicolumn{2}{|c|}{ CL } & $\mathrm{mL} / \mathrm{min} / \mathrm{kg}$ & 47.9 & 57.2 & 54.8 & 53.3 & 4.8 & 9.09 \\
\hline \multicolumn{2}{|c|}{$\mathrm{V}_{\mathrm{ss}}$} & $\mathrm{L} / \mathrm{kg}$ & 9.31 & 7.34 & 7.78 & 8.15 & 1.03 & 12.7 \\
\hline \multicolumn{2}{|c|}{ Terminal $t_{1 / 2}$} & $\mathrm{hr}$ & 4.5 & 2.2 & 2.7 & 3.1 & 1.2 & 37.6 \\
\hline \multicolumn{2}{|c|}{$\mathrm{AUC}_{\mathrm{INF}}$} & hr*ng/mL & 348 & 291 & 304 & 314 & 30 & 9.47 \\
\hline \multicolumn{2}{|c|}{$\mathrm{MRT}_{\mathrm{INF}}$} & $\mathrm{hr}$ & 3.2 & 2.1 & 2.4 & 2.6 & 0.6 & 22.5 \\
\hline \multicolumn{2}{|c|}{$\mathrm{V}_{\mathrm{z}}$} & $\mathrm{L} / \mathrm{kg}$ & 18.5 & 11.0 & 13.0 & 14.2 & 3.9 & 27.6 \\
\hline
\end{tabular}

BLOQ $<0.5 \mathrm{ng} / \mathrm{mL}$ 


\begin{tabular}{|c|c|c|c|c|c|c|c|c|}
\hline \multicolumn{9}{|c|}{$\begin{array}{l}\text { Individual and Mean Plasma Concentration-time Data of } \\
\text { Compound } 32 \text { after } 30 \mathrm{mg} / \mathrm{kg} \text { PO Administration in CD1 Mice }\end{array}$} \\
\hline \multirow{3}{*}{$\begin{array}{c}\text { Dose } \\
\text { (mg/kg) }\end{array}$} & \multirow{3}{*}{$\begin{array}{l}\text { Dose } \\
\text { route }\end{array}$} & \multirow{3}{*}{$\begin{array}{c}\text { Sampling } \\
\text { Time } \\
\text { (hr) }\end{array}$} & \multicolumn{3}{|c|}{ Concentration } & \multirow{3}{*}{$\begin{array}{c}\text { Mean } \\
\text { (ng/mL) }\end{array}$} & \multirow{3}{*}{$\begin{array}{c}\text { SD } \\
(\mathrm{ng} / \mathrm{mL})\end{array}$} & \multirow{3}{*}{$\begin{array}{l}\text { CV } \\
(\%)\end{array}$} \\
\hline & & & & (ng/mL) & & & & \\
\hline & & & Mouse7 & Mouse8 & Mouse9 & & & \\
\hline \multirow{8}{*}{30} & \multirow{8}{*}{$\mathrm{PO}$} & 0.25 & 211 & 1010 & 348 & 523 & 427 & 81.7 \\
\hline & & 0.5 & 241 & 924 & 604 & 590 & 342 & 58.0 \\
\hline & & 1 & 309 & 935 & 401 & 548 & 338 & 61.6 \\
\hline & & 2 & 266 & 918 & 446 & 543 & 337 & 62.0 \\
\hline & & 4 & 388 & 338 & 427 & 384 & 45 & 11.6 \\
\hline & & 7 & 87.7 & 61.6 & 66.6 & 72.0 & 13.9 & 19.2 \\
\hline & & 10 & 24.3 & 14.4 & 15.0 & 17.9 & 5.6 & 31.0 \\
\hline & & 24 & 0.702 & 0.720 & 0.735 & 0.719 & 0.017 & 2.30 \\
\hline \multicolumn{2}{|c|}{ PK parameters } & Unit & Mouse7 & Mouse8 & Mouse9 & Mean & SD & CV(\%) \\
\hline \multicolumn{2}{|c|}{$\mathrm{t}_{\max }$} & $\mathrm{hr}$ & 4.0 & 0.3 & 0.5 & 1.6 & 2.1 & 132 \\
\hline \multicolumn{2}{|c|}{$\mathrm{C}_{\max }$} & $\mathrm{ng} / \mathrm{mL}$ & 388 & 1010 & 604 & 667 & 316 & 47.3 \\
\hline \multicolumn{2}{|c|}{ Terminal $t_{1 / 2}$} & $\mathrm{hr}$ & 2.5 & 2.8 & 2.8 & 2.7 & 0.2 & 5.72 \\
\hline \multicolumn{2}{|c|}{$\mathrm{AUC}_{\mathrm{INF}}$} & hr*ng/mL & 2011 & 3571 & 2462 & 2681 & 803 & 29.9 \\
\hline \multicolumn{2}{|c|}{$\mathrm{MRT}_{\mathrm{INF}}$} & $\mathrm{hr}$ & 4.1 & 2.6 & 3.4 & 3.4 & 0.7 & 22.2 \\
\hline \multicolumn{2}{|c|}{$\mathrm{CL} / \mathrm{F}$} & $\mathrm{mL} / \mathrm{min} / \mathrm{kg}$ & 249 & 140 & 203 & 197 & 55 & 27.7 \\
\hline \multicolumn{2}{|c|}{$\mathrm{F}$ (AUC INF based) } & $\%$ & 21.3 & 37.9 & 26.1 & 28.4 & 8.5 & 29.9 \\
\hline \multicolumn{2}{|c|}{$\mathrm{F}_{\mathrm{a}}$} & & 0.52 & 0.93 & 0.64 & 0.70 & 0.21 & 30.2 \\
\hline
\end{tabular}

$\mathrm{BLOQ}<0.5 \mathrm{ng} / \mathrm{mL} ; \mathrm{Fa}=(\% \mathrm{~F} / 100) /\left(1-\left[\mathrm{CL} / \mathrm{Q}_{\mathrm{h}}\right]\right)$, where CL is observed blood clearance and $\mathrm{Q}_{\mathrm{h}}$ is liver blood flow (eg, $90 \mathrm{~mL} / \mathrm{min} / \mathrm{kg}$ for mice).

\begin{tabular}{|c|c|c|c|c|c|c|c|c|}
\hline \multicolumn{9}{|c|}{$\begin{array}{l}\text { Individual and Mean Plasma Concentration-time Data of } \\
\text { Compound } 32 \text { after } 100 \mathrm{mg} / \mathrm{kg} \text { PO Administration in CD1 Mice }\end{array}$} \\
\hline \multirow{2}{*}{$\begin{array}{c}\text { Dose } \\
\text { (mg/kg) }\end{array}$} & \multirow{2}{*}{$\begin{array}{l}\text { Dose } \\
\text { route }\end{array}$} & \multirow{2}{*}{$\begin{array}{c}\text { Sampling } \\
\text { Time } \\
\text { (hr) }\end{array}$} & \multicolumn{3}{|c|}{ Concentration } & \multirow{2}{*}{$\begin{array}{c}\text { Mean } \\
\text { (ng/mL) }\end{array}$} & \multirow{2}{*}{$\begin{array}{c}\text { SD } \\
(\mathrm{ng} / \mathrm{mL})\end{array}$} & \multirow{2}{*}{$\begin{array}{l}\text { CV } \\
(\%)\end{array}$} \\
\hline & & & Mouse7 & $\begin{array}{l}\text { (ng/mL) } \\
\text { Mouse8 }\end{array}$ & & & & \\
\hline \multirow{8}{*}{100} & \multirow{8}{*}{$\mathrm{PO}$} & 0.25 & 1720 & 655 & 3430 & 1935 & 1400 & 72.3 \\
\hline & & 0.5 & 2750 & 1890 & 4860 & 3167 & 1528 & 48.3 \\
\hline & & 1 & 3770 & 2230 & 3780 & 3260 & 892 & 27.4 \\
\hline & & 2 & 2850 & 3350 & 3000 & 3067 & 257 & 8.37 \\
\hline & & 4 & 2320 & 2270 & 3250 & 2613 & 552 & 21.1 \\
\hline & & 7 & 477 & 1410 & 1460 & 1116 & 554 & 49.6 \\
\hline & & 10 & 107 & 636 & 522 & 422 & 278 & 66.0 \\
\hline & & 24 & 1.45 & 6.52 & 5.82 & 4.60 & 2.75 & 59.8 \\
\hline \multicolumn{2}{|c|}{ PK parameters } & Unit & Mouse7 & Mouse8 & Mouse9 & Mean & SD & CV(\%) \\
\hline \multicolumn{2}{|c|}{$t_{\max }$} & $\mathrm{hr}$ & 1.0 & 2.0 & 0.5 & 1.2 & 0.8 & 65.5 \\
\hline
\end{tabular}




\begin{tabular}{|c|c|c|c|c|c|c|c|}
\hline $\mathrm{C}_{\max }$ & $\mathrm{ng} / \mathrm{mL}$ & 3770 & 3350 & 4860 & 3993 & 779 & 19.5 \\
\hline Terminal $t_{1 / 2}$ & hr & 2.1 & 2.2 & 2.1 & 2.1 & 0.0 & 1.67 \\
\hline $\mathrm{AUC}_{\mathrm{INF}}$ & hr*ng/mL & 15400 & 20000 & 24300 & 19900 & 4440 & 22.3 \\
\hline $\mathrm{MRT}_{\text {INF }}$ & $\mathrm{hr}$ & 3.3 & 5.0 & 4.3 & 4.2 & 0.9 & 21.1 \\
\hline $\mathrm{CL} / \mathrm{F}$ & $\mathrm{mL} / \mathrm{min} / \mathrm{kg}$ & 108 & 83.1 & 68.6 & 87 & 20 & 23.0 \\
\hline $\mathrm{F}$ (AUC $\mathrm{AINF}_{\mathrm{IN}}$ based) & $\%$ & 49.1 & 63.8 & 77.3 & 63.4 & 14.1 & 22.3 \\
\hline $\mathrm{F}_{\mathrm{a}}$ & & $>1$ & $>1$ & $>1$ & $>1$ & NA & NA \\
\hline
\end{tabular}

$\mathrm{Fa}=(\% \mathrm{~F} / 100) /\left(1-\left[\mathrm{CL} / \mathrm{Q}_{\mathrm{h}}\right]\right)$, where CL is observed blood clearance and $\mathrm{Q}_{\mathrm{h}}$ is liver blood flow $(\mathrm{eg}, 90 \mathrm{~mL} / \mathrm{min} / \mathrm{kg}$ for mice).

\section{Crystallography Protocols}

Crystallographic data collection and refinement statistics

\begin{tabular}{|c|c|c|c|}
\hline Compound & 2 & 20 & 32 \\
\hline PDB code & 7LZB & 7LZD & 7ZLF \\
\hline Cofactor & SAM & SAM & SAM \\
\hline Space group & P 212121 & P 212121 & P 212121 \\
\hline$a, b, c(\AA)$ & $51.55,76.75,77.78$ & $52.23,76.38,76.43$ & $49.91,76.65,76.19$ \\
\hline$\alpha, \beta, \gamma\left(^{\circ}\right)$ & $90.0,90.0,90.0$ & $90.0,90.0,90.0$ & $90 ., 90.0,90.0$ \\
\hline Resolution range $(\AA)$ & $54.63-2.28$ & $54.03-1.80$ & $36.39-2.47$ \\
\hline (Highest resolution shell) & $2.34-2.28$ & $1.86-1.80$ & $2.57-2.47$ \\
\hline $\mathrm{R}_{\text {merge, }}$ overall ${ }^{1}$ & 0.11 & 0.13 & 0.07 \\
\hline Completeness, overall (\%) & 98.7 & 99.3 & 99.4 \\
\hline Reflections, unique & 13698 & 27382 & 10278 \\
\hline Multiplicity & 6.2 & 6.1 & 6.6 \\
\hline $\mathrm{I} / \sigma$ & 2.38 & 2.52 & 1.89 \\
\hline $\mathrm{R}_{\text {value }}$ work $(\%)^{3}$ & 20.5 & 19.3 & 21.6 \\
\hline $\mathrm{R}_{\text {value free (\%) }}$ & 26.4 & 21.8 & 26.3 \\
\hline \multicolumn{4}{|l|}{ R.M.S. deviations from ideal } \\
\hline Bond lengths $(\AA)$ & 0.51 & 0.51 & 0.63 \\
\hline Bond angles $\left({ }^{\circ}\right)$ & 0.72 & 0.76 & 0.72 \\
\hline \multicolumn{4}{|c|}{$\Phi, \Psi$ angle distributions for residues ${ }^{3}$} \\
\hline In preferred regions (\%) & 97 & 98 & 97 \\
\hline In allowed regions (\%) & 3 & 2 & 3 \\
\hline Outliers (\%) & 0 & 0 & 0 \\
\hline
\end{tabular}

${ }^{1} \mathrm{R}_{\text {merge }}=\Sigma_{\text {hkl }}\left[\left(\Sigma_{\mathrm{i}}\left|I_{i}-<I>\right|\right) / \Sigma_{\mathrm{i}} I_{i}\right]$

${ }^{2} \mathrm{R}_{\text {value }}=\Sigma_{\text {hkl }}|| F_{\text {obs }}|-| F_{\text {calc }}|| / \Sigma_{\text {hkl }}\left|F_{\text {obs }}\right|$

${ }^{3}$ Ramachandran statistics as defined Engh \& Huber (2001)

Supplementary Table S7: Crystallographic collection parameters.

Protein Production: SETD2 (1434-1711) was purified from an insect cell expression system. The protein sequence was incorporated in a pFastBacHTb-lic with N-His-TEV and expressed in HF cells for 72 hours. Post-harvest the cells were resuspended in 25mM HEPES, $200 \mathrm{mM} \mathrm{NaCl}, 5 \mathrm{mM} \beta$-ME, pH 7.5 (buffer A) at a concentration of $1 \mathrm{~g}$ cell per $8 \mathrm{ml}$ buffer. Roche protease inhibitor cocktail and 0.5\% CHAPS was added. The mixture was incubated on ice for $30 \mathrm{~min}$. The suspension was sonicated at $200 \mathrm{~W}$ with a $3 \mathrm{sec}$ on, $5 \mathrm{sec}$ off cycle seventy times. The sample was centrifuged at $13,000 \mathrm{rpm}$ for $30 \mathrm{~min}$ at $4^{\circ} \mathrm{C}$, the supernatant was collected. 
A 20ml CV XK Qiagen Ni affinity column was used. Resin was preincubated with buffer A, then incubated with the sonication supernatant for 2 hours at 4C. The resin was washed with 25mM HEPES, 200mM NaCl, $5 \mathrm{mM} \beta$-ME, $20 \mathrm{mM}$ imidazole, $\mathrm{pH} 7.5$ (buffer B) until no UV signal was observed. The protein was eluted with 10CV of $25 \mathrm{mM}$ HEPES, 200mM NaCl, 5mM $\beta$-ME, 250mM imidazole, pH 7.5 (buffer C). A 12\% SDS-PAGE gel was used to identify the fractions containing the protein.

TEV protease was added at a ratio of 1:20 relative to SETD2 and the sample was incubated overnight.

The cleaved sample was applied to a 10ml CV XK Qiagen NI affinity column. The resin was pre-equilibrated with buffer A, and the sample was loaded onto the column. The column was washed with $25 \mathrm{mM}$ HEPES, 200mM NaCl, $5 \mathrm{mM} \beta$-ME, 10mM imidazole, $\mathrm{pH} 7.5$ (buffer D) for 6CV and buffer C for $5 \mathrm{CV}$.

The flowthrough from the affinity column was concentrated and applied to a Superdex 200 column preincubated with $25 \mathrm{mM}$ HEPES, $200 \mathrm{mM} \mathrm{NaCl}, 5 \mathrm{mM} \beta$-ME, $10 \mathrm{mM}$ imidazole, $\mathrm{pH} 7.5$ (buffer E). Fractions containing the protein were collected, concentrated to $36 \mathrm{mg} / \mathrm{ml}$ and flash frozen on liquid nitrogen.

X-ray crystallography: SETD2 (1434-1711) protein was concentrated to $10 \mathrm{mg} / \mathrm{ml}$ in a protein buffer containing $25 \mathrm{mM}$ HEPES, 200mM NaCl, $5 \mathrm{mM} \beta$-ME, $\mathrm{pH} 7.5,20 \mathrm{mg} / \mathrm{ml} \mathrm{SETD2,} \mathrm{3mM} \mathrm{SAH} \mathrm{and} \mathrm{2mM} \mathrm{compound.} \mathrm{A}$ crystallization reservoir solution of $0.1 \mathrm{M}$ Potassium thiocyanate, 0.1M Tris pH7.8, 25\% w/v PEG2000MME was used. Using a hanging drop method with seeding $1 \mu \mathrm{L}$ of protein solution was combined with $1 \mu \mathrm{L}$ of reservoir solution. Crystals were cryo-protected with the addition of $10 \%$ glycerol. Diffraction data was collected on BL19U1 at the SSRF or MX2 at AS. Data was reduced with either HKL3000 or XDS and refined with Refmac5. Data collection details and structure details are in the accompanying table. 


\section{References:}

1. Cheng Y, Prusoff WH. 1973. Relationship between the inhibition constant (k1) and the concentration of inhibitor which causes 50 per cent inhibition (i50) of an enzymatic reaction. Biochem Pharmacol. 22(23):3099-3108.

2. Knutson SK, Wigle TJ, Warholic NM, Sneeringer CJ, Allain CJ, Klaus CR, Sacks JD, Raimondi A, Majer CR, Song J et al. 2012. A selective inhibitor of ezh2 blocks h3k27 methylation and kills mutant lymphoma cells. Nat Chem Biol. 8(11):890-896. 